\author{
Mon ograph \\ urn:lsid:zoobank.org:pub:41385EAB-F391-468D-89CA-F7A574F820AB
}

\title{
New Cheilostomata (Bryozoa) from NE Atlantic seamounts, islands, and the continental slope: evidence for deep-sea endemism
}

\author{
Björn BERNING ${ }^{1, *}$, Jean-Georges HARMELIN ${ }^{2} \&$ Beate BADER $^{3}$ \\ ${ }^{1}$ Oberösterreichisches Landesmuseum, Geowissenschaftliche Sammlungen, 4060 Leonding, Austria. \\ ${ }^{1}$ CIBIO, Centro de Investigação em Biodiversidade e Recursos Genéticos, InBIO Laboratório \\ Associado, Pólo dos Açores, 9501-801 Ponta Delgada, Açores, Portugal. \\ ${ }^{2}$ Aix-Marseille University, Mediterranean Institute of Oceanography, OSU Pytheas, \\ Station Marine d'Endoume, 13007 Marseille, France. \\ ${ }^{3}$ Institut für Geowissenschaften, Christian-Albrechts-Universität, 24118 Kiel, Germany. \\ ${ }^{*}$ Corresponding author: b.berning@landesmuseum.at \\ 2Email: jean-georges.harmelin@univ-amu.fr \\ ${ }^{3}$ Email: bbader@online.no \\ ${ }^{1}$ urn:Isid:zoobank.org:author:30D7D0DB-F379-4006-B727-E75A0720BD93 \\ ${ }^{2}$ urn:Isid:zoobank.org:author:D11AE07A-CFD9-41EE-B3F9-6E0472150300 \\ ${ }^{3}$ urn:lsid:zoobank.org:author:AA3BCFDC-524D-4648-9268-F0F1C94B9A68
}

\begin{abstract}
Ten new species belonging to three new genera (Atlantisina gen. nov., Bathycyclopora gen. nov., Calvetopora gen. nov.) of umbonulomorph bryozoans from northeastern Atlantic seamounts, islands, and the continental slope are introduced. We furthermore erect the new family Atlantisinidae fam. nov. for these genera. Eight new species belong to the new genus Atlantisina: Atlantisina atlantis gen. et sp. nov. (type species), A. acantha gen. et sp. nov., A. gorringensis gen. et sp. nov., A. inarmata gen. et sp. nov., A. lionensis gen. et sp. nov., A. meteor gen. et sp. nov., A. seinensis gen. et sp. nov., and A. tricornis gen. et sp. nov. The genus Bathycyclopora gen. nov. is introduced for ?Phylactella vibraculata Calvet from the Azores, and also includes Bathycyclopora suroiti gen. et sp. nov. The type species of Calvetopora gen. nov. is Lepralia inflata Calvet from the Gulf of Cadiz; this genus also includes Calvetopora otapostasis gen. et sp. nov. and another species left in open nomenclature. Of the 13 species described herein, 11 occur on seamounts and islands, and nine species are endemic to a single seamount, island or station. The present results show that bryozoans provide striking examples of the function of seamounts as areas of endemism, most likely intrinsically linked to the low dispersal abilities of bryozoan larvae.
\end{abstract}

Keywords. Bathyal, biodiversity, biogeography, Macaronesia, taxonomy.

Berning B., Harmelin J.-G. \& Bader B. 2017. New Cheilostomata (Bryozoa) from NE Atlantic seamounts, islands, and the continental slope: evidence for deep-sea endemism. European Journal of Taxonomy 347: 1-51. https://doi. org/10.5852/ejt.2017.347 


\section{Introduction}

Seamount faunas have received a considerable amount of scientific attention during the last two decades (e.g., Richer de Forges et al. 2000; Stocks 2004; McClain 2007). Especially in the northeastern (NE) Atlantic, biological sampling during numerous expeditions resulted in the description of a substantial number of seamount taxa such as, foraminifera (Heinz et al. 2004), sponges (Xavier \& van Soest 2007), gastropods (Gofas 2007), polychaetes (Gillet \& Dauvin 2003), copepods (George \& Schminke 2002), ophiuroids (Bartsch 2008), or fish (Christiansen et al. 2009). Yet, although bryozoans are known to form significant proportions of the diversity of benthic seamount faunas (Rowden et al. 2002, 2004; Stocks 2004), the phylum has been ignored almost completely. Therefore, even in the relatively wellstudied North Atlantic, our knowledge on the number of bathyal and offshore bryozoan species and their geographic distribution is still extremely poor, and the bryozoan faunas of only two seamounts have so far been studied in greater detail (Harmelin 1977; Souto et al. 2016). Moreover, major previous works on seamounts, oceanic islands, and the continental slope in this region (Busk 1884; Jullien \& Calvet 1903; Calvet 1907, 1931; d'Hondt 1973, 1975; Harmelin 1977; Hayward 1978) mostly predate the use of scanning electron microscopy, which is crucial for the species-level identification of bryozoans. Revisions of these historical records are therefore necessary and often result in the splitting of species complexes, introduction of new taxa, and an increasing realisation of endemicity (e.g., Harmelin \& Arístegui 1988; Harmelin 2006; López-Fé 2006; Berning \& Kuklinski 2008; Souto et al. 2011; Berning 2012, 2013; Reverter-Gil \& Souto 2015; Reverter-Gil et al. 2015).

The NE Atlantic islands and seamounts are not evenly distributed. Located relatively close to the southwest Iberian and northwest African continental shelves, several clusters of large volcanic structures are confined to hot spot tracks and fault systems (e.g., Geldmacher et al. 2006). For instance, from the sites studied in this work, the Canary Islands, Gorringe Bank and Galicia Bank are situated relatively close to the continents. Several seamounts, such as Ampère, Lion and Seine, cluster along the MadeiraTore Rise towards the Madeira Archipelago, while all are separated from each other by abyssal depths. Another, more widely-spaced, group of islands and seamounts, the Azores in the north and the AtlantisGreat Meteor Seamount Chain in the south [comprising the Great Meteor Bank, Atlantis Seamount (Smt), Hyères Smt and Lion Smt], is formed by fault-system volcanism associated with the Mid-Atlantic Ridge. This group is separated from the continental shelf, and from the other seamounts mentioned above, by vast stretches of abyssal depths that are almost devoid of any prominent volcanic structures. Most of the seamounts and all of the modern archipelagos originated during the Miocene, while certain seamounts (e.g., Lion Smt: ca $80 \mathrm{Ma}$ ) and banks (e.g., Gorringe Bank: ca $75 \mathrm{Ma}$ ) are considerably older (Geldmacher et al. 2006). The minimum depth of the sampled seamount tops varies considerably as well: from as little as $20 \mathrm{~m}$ (Gorringe Bank) to some $600 \mathrm{~m}$ (Galicia Bank) below the sea surface.

As part of an ongoing study of the bryozoan faunas from NE Atlantic islands and seamounts, we here describe a new family, three new genera, and ten new species of bathyal, umbonulomorph bryozoans, while two previously recorded species are redescribed. We discuss possible phylogenetic relationships to other known taxa, as well as the geographic distribution and ecomorphology of these bryozoans.

\section{Material and methods}

The bryozoan material studied here was collected during various oceanographic cruises to NE Atlantic seamounts and the continental slope by means of dredges and epibenthic sleds. Most material was collected during French expeditions with the research vessels 'Calypso' (1959) as well as during the 'Thalassa' (1968, 1971, 1972), 'Noroît' (Seamount 1, 1987) and 'Suroît' (Seamount 2, 1993) cruises. Additional samples were collected during the German 'RV Meteor' cruises M19 (1970) and M42/3 (1998) to the Great Meteor Bank, and the Spanish 'Indemares BANGAL 0811' expedition to Galicia Bank (2011). Historical material of Lepralia inflata Calvet, 1906 from the Gulf of Cádiz was collected 
on the 'Talisman' cruise (1883), and that of ?Phylactella vibraculata Calvet, 1931 from the Azores on the 'Prince Albert Ir de Monaco' cruise (1897). The sampling localities are provided in Table 1, and the type and other material of each species is referenced in the text using the station numbers given in the first column.

All material was preserved dry. Selected specimens were cleaned with sodium hypochlorite, coated with gold-platinum and photographed using a Camscan (Serie-2-CS-44) and a FEI Inspect S50 scanning electron microscope (SEM) at the University of Kiel, a Hitachi S570 SEM at the Station Marine d'Endoume, and a FEI Inspect S50 SEM at the University of Vienna. The material is kept at the Muséum national d'Histoire naturelle in Paris (MNHN), the Musée océanographique de Monaco (MOM), the Oberösterreichisches Landesmuseum in Linz (OLL; collection Invertebrata except Insecta), and at the Senckenberg Museum und Forschungsinstitut in Frankfurt (SMF).

Morphometry was done using an eyepiece micrometre. The values are given in microns ( $\mu \mathrm{m})$ unless otherwise stated. We provide the mean value \pm standard deviation (SD) and the number of measurements taken (\#). One-way Analysis of Variance (ANOVA) and all pairs post hoc Tukey's tests were performed on certain sets of the original measurements in order to analyse intercolonial morphometric variability. Abbreviations of measured characters:

$\begin{array}{ll}\text { aAL } & =\text { adventitious avicularium length } \\ \text { aAW } & =\text { adventitious avicularium width } \\ \mathrm{iAL} & =\text { interzooidal avicularium length } \\ \mathrm{iAW} & =\text { interzooidal avicularium width } \\ \mathrm{OL} & =\text { orifice length } \\ \mathrm{OW} & =\text { orifice width } \\ \mathrm{OvL} & =\text { ooecium length } \\ \mathrm{OvL} / \mathrm{W} & =\text { ratio of ooecium length to width } \\ \mathrm{OvW} & =\text { ooecium width } \\ \mathrm{ZL} & =\text { zooecium length } \\ \mathrm{ZW} & =\text { zooecium width }\end{array}$

\section{Results}

Suborder Neocheilostomina d'Hondt, 1985

Superfamily Lepralielloidea Vigneaux, 1949

Family Atlantisinidae fam. nov. urn:1sid:zoobank.org:act:17F29C69-ECAC-4D27-A3B6-DE8C96009930

\section{Type genus}

Atlantisina gen. nov.

\section{Diagnosis}

Colonies encrusting; autozooidal frontal shield umbonuloid, imperforate or pseudoporous. Orifice with condyles, oral spines present. Adventitious and/or interzooidal avicularia present in some taxa. Lateral walls with basal pore-chambers, usually well developed, interzooidal commmunication via a single or few septular pores per neighbouring zooid, budding intrazooidal. Ovicell hyperstomial, ooecium either produced by the zooid distal to the maternal one or of kenozooidal origin, not closed by the operculum, the distal pair of oral spines closely appressed to the sides of the short, tubular ooecial opening; the kenozooidal ooecium may be entirely independent of the substratum and distal zooid, and may be 
Table 1. List of sampling cruises and the respective stations (Stn \#) of the material examined in this paper. The consecutive station numbers in the first column (Stn) are referenced to in the material section of the respective species.

\begin{tabular}{|c|c|c|c|c|c|c|c|}
\hline Stn & Locality & Cruise & Stn \# & Date & Long. N & Lat. W & Depth (m) \\
\hline 1 & Ampère Seamount & Seamount 1 & СР 99 & 12 Oct. 1987 & $35^{\circ} 03.8^{\prime}$ & $12^{\circ} 55.4^{\prime}$ & $225-280$ \\
\hline 2 & Azores & Prince Albert & 866 & 2 Aug. 1897 & $38^{\circ} 52.50^{\prime}$ & $27^{\circ} 23.05^{\prime}$ & 599 \\
\hline 3 & Atlantis Seamount & Seamount 2 & DW 254 & 1 Feb. 1993 & $34^{\circ} 05.35^{\prime}$ & $30^{\circ} 13.41^{\prime}$ & $275-280$ \\
\hline 4 & Atlantis Seamount & Seamount 2 & DW 255 & 2 Feb. 1993 & $34^{\circ} 04.92^{\prime}$ & $30^{\circ} 15.27^{\prime}$ & $335-340$ \\
\hline 5 & Atlantis Seamount & Seamount 2 & DW 256 & 2 Feb. 1993 & $34^{\circ} 06.21^{\prime}$ & $30^{\circ} 16.03^{\prime}$ & $340-345$ \\
\hline 6 & Atlantis Seamount & Seamount 2 & СР 257 & 2 Feb. 1993 & $34^{\circ} 04.51^{\prime}$ & $30^{\circ} 15.05^{\prime}$ & $330-338$ \\
\hline 7 & Atlantis Seamount & Seamount 2 & DW 258 & 2 Feb. 1993 & $33^{\circ} 59.83^{\prime}$ & $30^{\circ} 12.15^{\prime}$ & $420-460$ \\
\hline 8 & Atlantis Seamount & Seamount 2 & DW 274 & 5 Feb. 1993 & $34^{\circ} 05.13^{\prime}$ & $30^{\circ} 13.57^{\prime}$ & 280 \\
\hline 9 & Canary Islands & Seamount 2 & DW 126 & 5 Jan. 1993 & $28^{\circ} 07.59^{\prime}$ & $15^{\circ} 52.05^{\prime}$ & 345 \\
\hline 10 & Canary Islands & Seamount 2 & DW 128 & 6 Jan. 1993 & $28^{\circ} 08.26^{\prime}$ & $15^{\circ} 51.99^{\prime}$ & $470-485$ \\
\hline 11 & Canary Islands & Seamount 2 & DW 129 & 6 Jan. 1993 & $28^{\circ} 08.32^{\prime}$ & $15^{\circ} 51.94^{\prime}$ & 480 \\
\hline 12 & Canary Islands & Seamount 2 & DW 130 & 6 Jan. 1993 & $28^{\circ} 08.95^{\prime}$ & $15^{\circ} 53.11^{\prime}$ & $655-660$ \\
\hline 13 & Galicia Bank & BANGAL 0811 & DR 02 & 20 Jul. 2011 & $43^{\circ} 00.4^{\prime}$ & $11^{\circ} 51.0^{\prime}$ & 1697 \\
\hline 14 & Galicia Bank & Seamount 1 & DW 110 & 19 Oct. 1987 & $42^{\circ} 37.2^{\circ}$ & $11^{\circ} 31.8^{\circ}$ & $825-835$ \\
\hline 15 & Galicia Bank & Seamount 1 & DW 111 & 19 Oct. 1987 & $42^{\circ} 39.9^{\prime}$ & $11^{\circ} 35.8^{\circ}$ & $675-685$ \\
\hline 16 & Galicia Bank & Seamount 1 & DW 116 & 20 Oct. 1987 & $42^{\circ} 52.4^{\circ}$ & $11^{\circ} 50.6^{\circ}$ & 985-1000 \\
\hline 17 & Gorringe Bank & Seamount 1 & DW 5 & 22 Sep. 1987 & $36^{\circ} 32^{\prime}$ & $11^{\circ} 37.9^{\prime}$ & 180 \\
\hline 18 & Gorringe Bank & Seamount 1 & DW 15 & 22 Sep. 1987 & $36^{\circ} 33.4^{\prime}$ & $11^{\circ} 28.8^{\prime}$ & $300-330$ \\
\hline 19 & Great Meteor Bank & Meteor 19 & 132 & 18 Feb. 1970 & $29^{\circ} 48.5^{\prime}$ & $28^{\circ} 22.5^{\prime}$ & 392-394 \\
\hline 20 & Great Meteor Bank & Meteor $42 / 3$ & 483 & 7 Sep. 1998 & $30^{\circ} 05.2^{\prime}$ & $28^{\circ} 26.5^{\prime}$ & 333 \\
\hline 21 & Great Meteor Bank & Meteor $42 / 3$ & 514 & 13 Sep. 1998 & $29^{\circ} 57.7^{\prime}$ & $28^{\circ} 21.7^{\prime}$ & 330 \\
\hline 22 & Great Meteor Bank & Meteor $42 / 3$ & 565 & 21 Sep. 1998 & $29^{\circ} 39.4^{\prime}$ & $28^{\circ} 22.9^{\prime}$ & 403 \\
\hline 23 & Great Meteor Bank & Seamount 2 & СР 146 & 10 Jan. 1993 & $30^{\circ} 11.19^{\prime}$ & $28^{\circ} 28.07^{\prime}$ & $370-420$ \\
\hline 24 & Gulf of Cádiz & Talisman & DR 10 & 10 Jun. 1883 & $35^{\circ} 26^{\prime}$ & $06^{\circ} 48.46^{\prime}$ & 717 \\
\hline 25 & Hyères Seamount & Calypso & drag. 3 & 13 Aug. 1959 & $31^{\circ} 29.4^{\prime}$ & $28^{\circ} 58^{\prime}$ & 290 \\
\hline 26 & Hyères Seamount & Seamount 2 & DW 182 & 16 Jan. 1993 & $31^{\circ} 23.23^{\prime}$ & $28^{\circ} 53.46^{\prime}$ & 480 \\
\hline 27 & Hyères Seamount & Seamount 2 & DW 183 & 16 Jan. 1993 & $31^{\circ} 23.29^{\prime}$ & $28^{\circ} 53.39^{\prime}$ & $490-485$ \\
\hline 28 & Hyères Seamount & Seamount 2 & DW 188 & 17 Jan. 1993 & $31^{\circ} 29.95^{\prime}$ & $28^{\circ} 59.54^{\prime}$ & $300-310$ \\
\hline 29 & Hyères Seamount & Seamount 2 & DW 190 & 17 Jan. 1993 & $31^{\circ} 28.95^{\prime}$ & $29^{\circ} 00.02^{\prime}$ & $675-750$ \\
\hline 30 & Hyères Seamount & Seamount 2 & DW 191 & 17 Jan. 1993 & $31^{\circ} 30.16^{\prime}$ & $28^{\circ} 58.91^{\prime}$ & 295-301 \\
\hline 31 & Irving Seamount & Seamount 2 & DW 205 & 26 Jan. 1993 & $32^{\circ} 01.10^{\prime}$ & $27^{\circ} 57.19^{\prime}$ & $348-355$ \\
\hline 32 & Irving Seamount & Seamount 2 & DW 209 & 26 Jan. 1993 & $31^{\circ} 59.17^{\prime}$ & $27^{\circ} 55.95^{\prime}$ & $435-460$ \\
\hline 33 & Irving Seamount & Seamount 2 & DW 210 & 26 Jan. 1993 & $32^{\circ} 02.56^{\prime}$ & $27^{\circ} 56.72^{\prime}$ & $325-330$ \\
\hline 34 & Irving Seamount & Seamount 2 & DW 215 & 27 Jan. 1993 & $31^{\circ} 53.59^{\prime}$ & $28^{\circ} 02.88^{\prime}$ & $270-275$ \\
\hline 35 & Le Danois Bank & Thalassa & X 342 & 16 Oct. 1971 & $44^{\circ} 07.5^{\prime}$ & $04^{\circ} 36.2^{\prime}$ & 700 \\
\hline 36 & Lion Seamount & Seamount 1 & DW 63/64 & 8 Oct. 1987 & $35^{\circ} 15.4^{\prime}$ & $15^{\circ} 34.6^{\prime}$ & $625-630$ \\
\hline 37 & N Iberian slope & Thalassa & U 807 & 18 Oct. 1968 & $44^{\circ} 11.0^{\prime}$ & $08^{\circ} 40.2^{\prime}$ & $450-500$ \\
\hline 38 & N Iberian slope & Thalassa & U 844 & 23 Oct. 1968 & $44^{\circ} 12.1^{\prime}$ & $08^{\circ} 42.1^{\prime}$ & 695-760 \\
\hline 39 & $\mathrm{~N}$ Iberian slope & Thalassa & Y 433 & 4 Sep. 1972 & $44^{\circ} 12^{\prime}$ & $08^{\circ} 40.5^{\prime}$ & $605-620$ \\
\hline 40 & $\mathrm{~N}$ Iberian slope & Thalassa & Y 434 & 4 Sep. 1972 & $44^{\circ} 12^{\prime}$ & $08^{\circ} 40.8^{\prime}$ & $600-620$ \\
\hline 41 & Seine Seamount & Seamount 1 & DW 77 & 10 Oct. 1987 & $33^{\circ} 48.7^{\prime}$ & $14^{\circ} 23.2^{\prime}$ & $235-250$ \\
\hline 42 & Seine Seamount & Seamount 1 & CP 79 & 10 Oct. 1987 & $33^{\circ} 49^{\prime}$ & $14^{\circ} 22.6^{\prime}$ & $242-260$ \\
\hline 43 & Seine Seamount & Seamount 1 & DE 82 & 10 Oct. 1987 & $33^{\circ} 47.7^{\prime}$ & $14^{\circ} 24.1^{\prime}$ & $320-400$ \\
\hline 44 & W Iberian slope & Thalassa & Y 401 & 1 Sep. 1972 & $40^{\circ} 36.8^{\prime}$ & $09^{\circ} 21.5^{\prime}$ & 1040 \\
\hline
\end{tabular}


budded from a distinct pore in the maternal zooid's distal wall; endooecium fully calcified, ectooecium partially calcified. Ancestrula tatiform with extensive opesia; cryptocyst absent.

\section{Remarks}

The taxa that are here combined in the Atlantisinidae fam. nov. are morphologcially somewhat similar to, and share some characters with, the families Escharellidae Levinsen, 1909, Exochellidae Bassler, 1935 and Romancheinidae Jullien, 1888, while the latter is occasionally considered to include the former two (D.P. Gordon, pers. comm. 2014). However, the new taxa described here share distinct traits, which can be regarded as relatively conservative in an evolutionary sense, that are not present in any of the existing families. Assigning the new genera to the Romancheinidae sensu lato would add yet another set of new characters to this large taxon, and would render the family difficult to define precisely, as well as to delimit it from other lepralielloid families, e.g., the Bryocryptellidae Vigneaux, 1949.

Characters common to the species in all three genera presented here comprise the partial calcification of the ectooecium and the position of the distalmost pair of spines in maternal zooids, which are so closely appressed to the peristomial aperture of the ooecium as to leave a furrow on each side when the spine is missing. The species usually have extensive lateral walls composed of smooth gymnocyst, and interzooidal communication takes place via one (occasionally two) large septular pores. Moreover, all species share the same ancestrula-type (tatiform with a large opesia that is somewhat constricted in the distal oral part, while the cryptocyst is practically absent).

In contrast, the representative taxa in the Romancheinidae sensu lato are characterised by ancestrulae with a reduced oval or otherwise shaped opesia that is often bounded by an extensive cryptocyst. The ooecium is also structurally different in that the ectooecium is membranous, and the endooecium fuses with the frontal shield of the distal auto- or kenozooid (Ostrovsky 2013). Both the relatively primitive structure of the ancestrula as well as the morphology of the ooecium in the new taxa may thus suggest that the new family forms a clade basal to the Romancheinidae sensu lato (further discussed below). Genetic studies will be needed to ultimately shed light on the phylogenetic relationships between the new taxa and the Romancheinidae, as well as among the taxa currently placed within the Romancheinidae.

Genus Atlantisina gen. nov.

urn:Isid:zoobank.org:act:B1994BA0-3091-4D78-A5C3-CE8BEE1A19D2

\section{Type species}

Atlantisina atlantis gen. et sp. nov.

\section{Diagnosis}

Colony encrusting, unilaminar, forming small patches or biserial to multiserial ribbons by intrazooidal budding. Frontal shield umbonuloid, imperforate except for very few minute marginal pores; gymnocystal lateral walls generally extensive, basal pore chambers present, communication via a single large exterior pore per neighbouring zooid that is bounded by a variably distinct cryptocystal rim, a single round and slightly raised septular pore present in the distal vertical wall. Orifice with condyles, proximal margin concave; oral spines present, paired, in two distolateral series with a distal gap. Ovicell hyperstomial, ooecium kenozooidal, budded from the maternal zooid through the distal septular pore; ectooecium partially calcified, proximally usually forming a short tubular apertural peristome wedged in between the distalmost pair of spines; calcified endooecium exposed in central area, surface variably structured, occasionally deeply pitted but imperforate; not closed by operculum (presumably acleithral). No avicularia. Ancestrula tatiform, gymnocyst fairly narrow all around, cryptocyst absent, opesia extensive, slightly constricted in distal (oral) part, surrounded by numerous mural spines; first generation autozooid single, budded distally or (disto)laterally. 


\section{Etymology}

Named for the occurrence of the type species on Atlantis Smt. Gender feminine.

\section{Remarks}

The combined occurrence of the following features distinguishes Atlantisina gen. nov. from all romancheinid genera as well as from the other new genera presented here: (i) a partly calcified ectooecium, (ii) the exclusively kenozooidal origin of the ooecium that is produced from a distinct communication pore in the maternal zooid's distal wall, (iii) the lack of avicularia, and (iv) the well-developed lateral walls, with a single large communication pore per neighbouring zooid.

The variably developed band of smooth ectooecium around the basal and proximal part of the ooecium is a distinctive character of Atlantisina gen. nov. species (Fig. 1A). Moreover, in the Romancheinidae and most of the remaining atlantisinids the ooecium is either produced by the zooid distal to the maternal zooid, or (much less often) by a distal kenozooid that has an encrusting base, including lateral walls with basal pore chambers from which the distal autozooids are budded. The ooecium in Atlantisina gen. nov. is also a kenozooid (Fig. 1A), but it is budded from a single large communication pore situated in the distal vertical wall of the maternal zooid (Fig. 1B). The pore is slightly raised relative to the remaining lateral communication pores and remains exposed above the frontal shield of the distal zooid throughout ontogeny. Formation of the ovicell may, therefore, not be restricted to the colony margin but may occur opportunistically at any stage during ontogeny whenever breeding conditions are optimal and eggs are fertilised. Owing to the elevated position of this pore the ooecial kenozooid is not in contact with the substratum and the basal ooecium is, if at all, barely touching the frontal shield(s) of subsequently budded distal zooid(s) (Fig. 1A, C). The ooecial kenozooid also lacks communication pores.

Thus, the Atlantisina gen. nov. ovicell differs structurally from the escharelliform ooecium present in the Romancheinidae sensu lato (see Ostrovsky 2013: 138). In the latter, the endooecium fuses with the frontal shield of the distal auto- or kenozooid, and the membranous ectooecium is continuous with the distal zooid's membranous frontal wall. The ooecium structure in Atlantisina gen. nov., as well as in the other new genera introduced here, can be regarded as evolutionarily more primitive relative to the escharelliform ooecium (A.N. Ostrovsky, pers. comm. 2016). On the other hand, the kenozooidal nature of the ooecium, and its origin from a distinct ooecial pore in the maternal zooid's distal wall, indicates a derived state within the Atlantisinidae.

The zooecium is divided into a variably sculptured, cryptocystal-type frontal shield and smooth gymnocystal calcification comprising the external lateral and distal vertical walls, including the distal part of the aperture, condyles, and oral spines (Fig. 1A-C). Moreover, the proximal margin of the aperture (i.e., the distal part of the umbonuloid frontal shield) is again composed of smooth gymnocyst, varying in extent from extremely narrow to extremely extensive when forming a suboral mucro (Fig. 1A-C). The interior-walled frontal shield and the gymnocystal lateral walls are separated by distinct sinusoidal sutures lateral to the orifice, leading in a bow to the proximal pair of spines and the condyles (Fig. 1C), where they meet (but do not fuse with) the gymnocystal calcification along the proximal aperture margin (which is again separated by a suture from the cryptocystal-type frontal shield along the proximal side of the mucro).

The usually extensively developed gymnocystal lateral walls are characteristic for Atlantisina gen. nov. species, comprising spacious basal pore chambers (Fig. 1D) with a single, large, external communication pore per neighbouring zooid, which is usually bounded by a distinct cryptocystal rim (Fig. 1B). In contrast, most Romancheinidae (e.g., Hemicyclopora Norman, 1894) have extremely reduced vertical walls with numerous small septula connecting the neighbouring zooids, and gymnocystal calcification is absent (e.g., Hayward \& Ryland 1999). The morphology and formation of the frontal shield and 
orifice is, nevertheless, vaguely similar between Atlantisina and several romancheinid taxa such as Hemicyclopora, Escharella Gray, 1848, and Escharoides Milne Edwards, 1836. Moreover, in the latter genus communication between laterally neighbouring zooids also takes place via a single pore, whereas the distal wall comprises two or three basal pore chambers from which the distal autozooid is budded.

The respective number of oral spines in all Atlantisina gen. nov. species is, quite remarkably, extremely constant within and among colonies. Atlantisina meteor gen. et sp. nov. (see below) was the only species
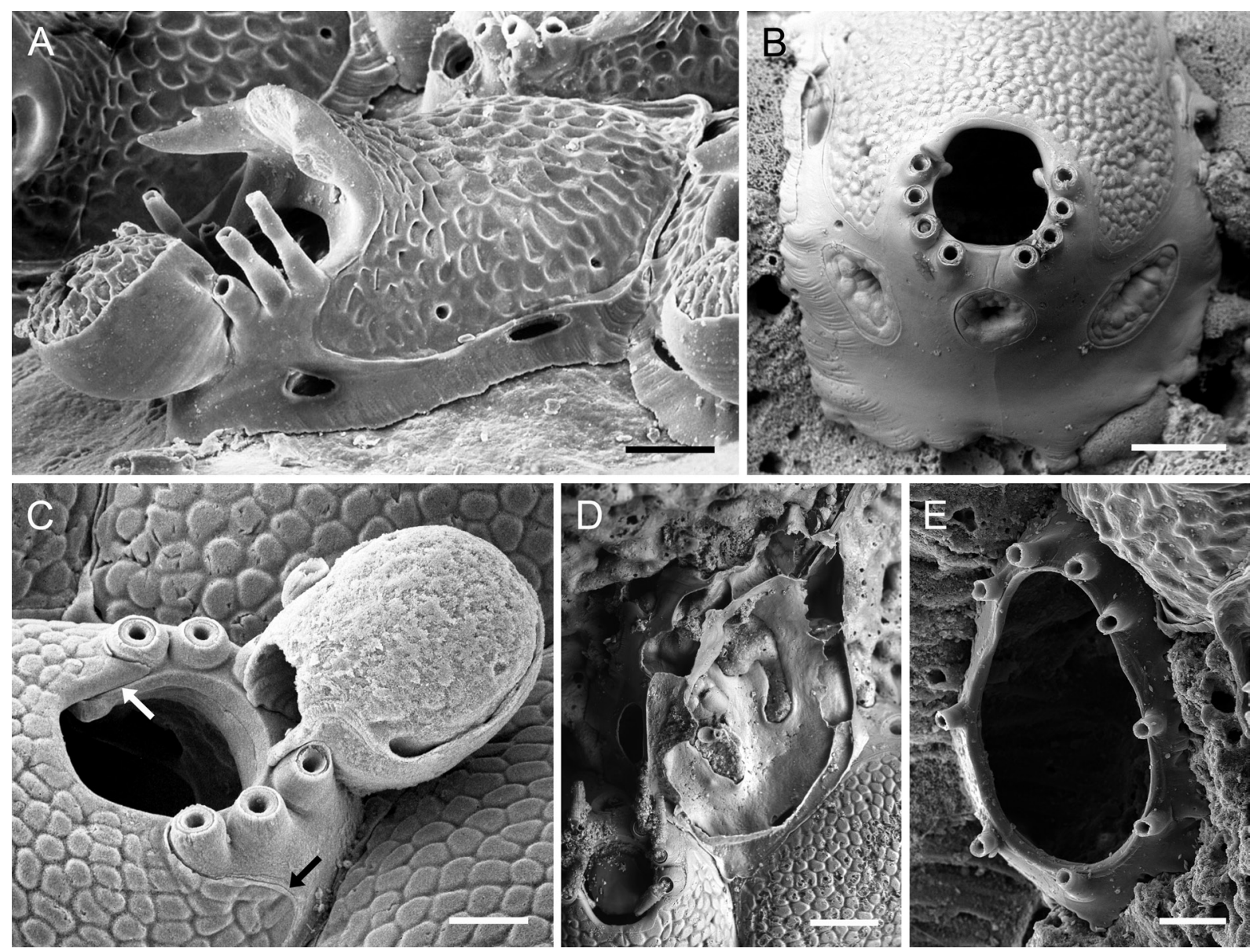

Fig. 1. Morphological characteristics of Atlantisina gen. nov. A. The kenozooidal ooecium of Atlantisina lionensis gen. et sp. nov. in lateral view (paratype MNHN-IB-2014-67), showing the broad band of ectooecium and the centrally exposed endooecium; note that the suboral crest is formed by smooth gymnocyst whereas the remaining frontal shield is cryptocystidean. B. Distal view of an autozooid of Atlantisina meteor gen. et sp. nov. showing two distolateral communication pores and the slightly raised central pore from which the ooecium is budded (paratype MNHN-IB-2014-50); note the broad band of cryptocyst bounding the septular pores, and that the remaining parts of the distolateral vertical walls and orifice are entirely gymnocystal. C. Oral region of an ovicellate zooid of Atlantisina atlantis gen. et sp. nov. (paratype MNHN-IB-2014-49), showing the contact between the cryptocystidean frontal shield and the gymnocystal distal part of the zooecium; note that the frontal shield is superpositioned on the condyles (white arrow) and meets the distolateral vertical walls in a sinusoidal suture (black arrow). D. Initial stages of zooid formation with the lateral walls being partly broken, showing the large basal pore chambers in Atlantisina atlantis gen. et sp. nov. (paratype OLL 2016/123). E. Slightly oblique view of the ancestrula of Atlantisina tricornis gen. et sp. nov. (paratype MNHN-IB-2014-64); note the simple tatiform morphology, the absence of a cryptocyst, and the slightly restricted oral region (top). Scale bars: $\mathrm{A}-\mathrm{B}, \mathrm{D}=100 \mu \mathrm{m} ; \mathrm{C}, \mathrm{E}=50 \mu \mathrm{m}$. 
in which a deviation (by one spine) from the specific number of spines occurred among auto- or ovicelled zooids. Even in early astogenetic zooids, which are usually equipped with a higher number of spines than mature zooids in most cheilostomatid species, the specific number of spines is already present.

The simple, tatiform ancestrula (Fig. 1E) buds a single distal to lateral autozooid, followed by one to three distolateral zooids that are either situated around the ancestrula or form distal to the first-generation autozooid, apparently depending on microenvironmental clues. While there is also a single firstgeneration autozooid in Escharella, Hemicyclopora and Neolagenipora Vigneaux, 1949, the ancestrula in Escharoides species usually produces two distolateral zooids (cf. Hayward \& Ryland 1999). The ancestrula in Atlantisina gen. nov. also differs from the romancheinid taxa in having a distinctly more extensive opesia, with a constriction in the distal oral part, and in the absence of a crpytocyst.

Species of Atlantisina gen. nov. are presently restricted to bathyal depths along the NE Atlantic continental shelf, islands and seamounts. The northernmost distribution is along the northern Iberian margin $\left(44^{\circ} \mathrm{N}\right)$ while Atlantisina gen. nov. was recorded as far west as Atlantis Smt $\left(30^{\circ} \mathrm{W}\right)$ and south to the Canary Islands $\left(28^{\circ} \mathrm{N}\right)$. No Recent species have been reported from the Mediterranean Sea but there is an early Pleistocene record from Sicily (A. Rosso, pers. comm. 2016).

Atlantisina atlantis gen. et sp. nov.

urn:lsid:zoobank.org:act:D2DA5614-66E4-4014-8FB5-7D931A22B5F2

Figs $1 \mathrm{C}-\mathrm{D}, 2 \mathrm{~A}-\mathrm{F}$, Table 2

\section{Diagnosis}

Frontal shield translucent, surface densely covered by large, flattened, irregularly polygonal nodules; lateral walls well-developed, septular pores large, round to transversely oval. Orifice margin with six oral spines; condyles short and blunt, no suboral mucro. Ovicell hyperstomial, ooecium globular, a little longer than wide; ectooecium relatively narrow, covering (less than) the lower half of ooecium; exposed endooecium relatively large and hemispherical, surface topography irregular, with no distinct pattern. Ancestrula with a pyriform opesia and nine mural spines.

\section{Etymology}

Named after its type locality, Atlantis Smt; used as a noun in apposition.

\section{Material examined}

\section{Holotype}

ATLANTIS SMT: a large ovicellate colony marked "H", together with three smaller colonies of A. atlantis gen. et sp. nov. and a young colony of Bathycyclopora suroiti gen. et sp. nov. (see below), on stylasterid skeleton, Stn 8 (MNHN-IB-2014-45).

\section{Paratypes}

ATLANTIS SMT: 1 colony on biogenic substrate, Stn 4 (MNHN-IB-2014-46); 3 colonies on a piece of stylasterid skeleton, Stn 7 (MNHN-IB-2014-47); 2 colonies on a piece of stylasterid skeleton, Stn 7 (MNHN-IB-2014-48); 1 coated colony on coral skeleton, Stn 8 (MNHN-IB-2014-49); 3 colonies on rock, Stn 7 (OLL 2016/122); 1 colony on coral, Stn 7 (OLL 2016/123); 2 colonies on coral, Stn 7 (OLL 2016/124).

\section{Other material examined}

ATLANTIS SMT: 3 colonies on coral skeleton, Stn 3 (unregistered MNHN material); 4 colonies on coral skeleton, Stn 4 (unregistered MNHN material); ca 33 colonies on coral and stylasterid skeletons, Stn 7 
BERNING B. et al., New bathyal Bryozoa from the NE Atlantic

Table 2. Measurements of Atlantisina atlantis gen. et sp. nov.

\begin{tabular}{ccccccc}
\hline & ZL & ZW & OL & OW & OvL & OvW \\
\hline Mean & 521 & 334 & 127 & 112 & 192 & 175 \\
SD & \pm 29 & \pm 23 & \pm 7 & \pm 5 & \pm 7 & \pm 16 \\
$\#$ & 20 & 20 & 10 & 10 & 10 & 10 \\
\hline
\end{tabular}

(unregistered MNHN material); 4 colonies on coral skeletons, Stn 8 (unregistered MNHN material); 6 colonies on coral, 1 on bivalve shell, Stn 7 (OLL 2016/125); 3 colonies on coral skeleton, Stn 7 (OLL 2016/126); 3 colonies on coral skeleton, Stn 7 (OLL 2016/127); 1 colony on coral skeleton, Stn 7 (OLL 2016/128); 8 colonies on stylasterid skeleton, Stn 7 (OLL 2016/129).

\section{Description}

Colony encrusting, unilaminar, forming small irregular patches or biserial to triserial branching ribbons (Fig. 2A). Zooecium outline oval distally, triangular proximally, wedged in between proximal zooecia
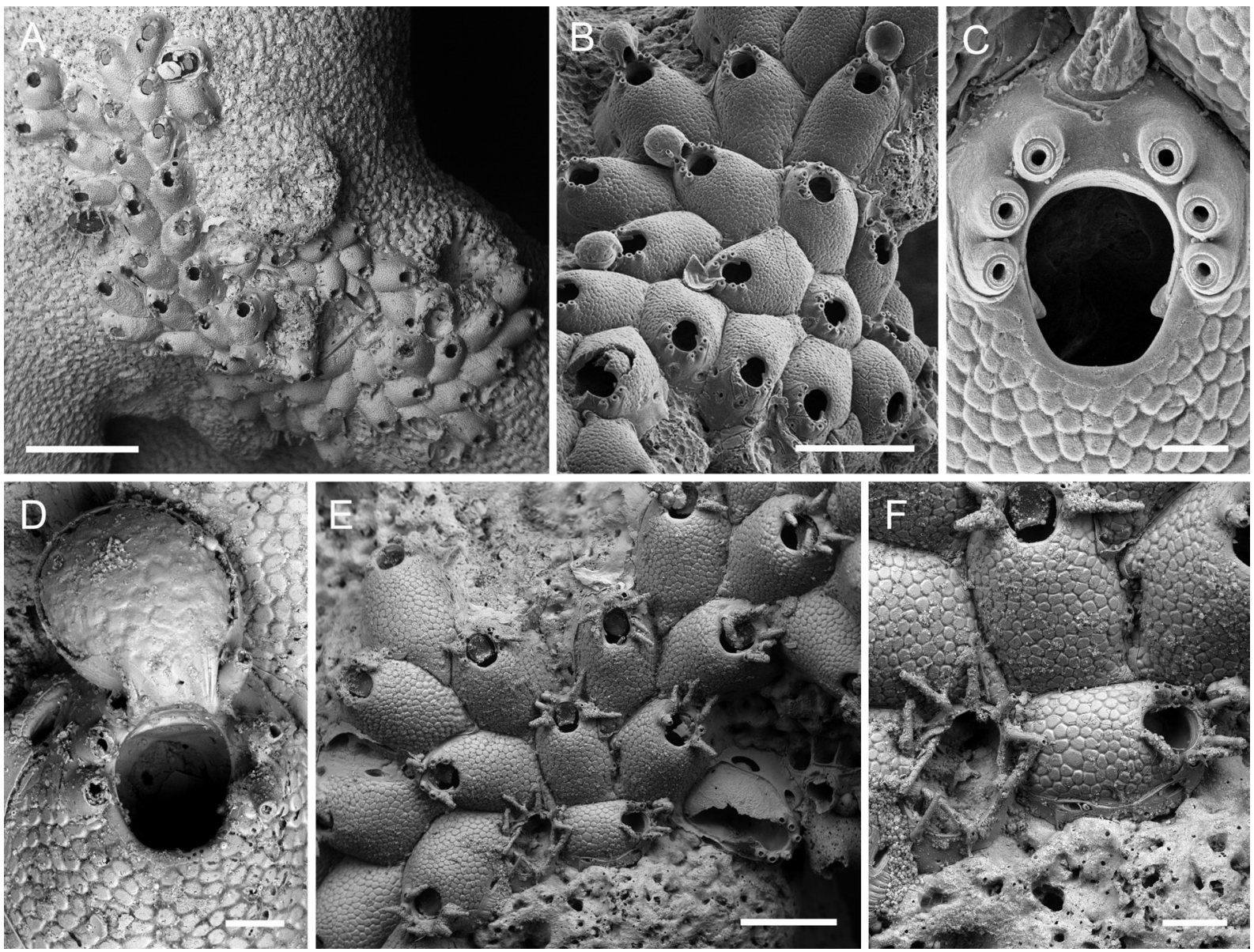

Fig. 2. Atlantisina atlantis gen. et sp. nov., Atlantis Smt. A. Overview of colony growing on a stylasterid skeleton; note the biserial-branching growth (paratype MNHN-IB-2014-47). B. Several autozooids and ovicellate zooids (paratype MNHN-IB-2014-49). C. Close-up of orifice and the base of a severed ovicell protruding from the distal communication pore (paratype MNHN-IB-2014-49). D. Ooecium (OLL 2016/127). E. Periancestrular region (paratype OLL 2016/123). F. Ancestrula and first-generation autozooid (paratype OLL 2016/123). Scale bars: A $=1 \mathrm{~mm} ; \mathrm{B}=500 \mu \mathrm{m} ; \mathrm{C}-\mathrm{D}=50 \mu \mathrm{m} ; \mathrm{E}=300 \mu \mathrm{m}$; $\mathrm{F}=100 \mu \mathrm{m}$. 
(Fig. 2B). Frontal shield matted vitreous, convex, densely covered by relatively large, evenly-spaced, irregularly polygonal and flattened nodules (Fig. 2C-F), imperforate except for five or six minute marginal pores, invisible in frontal view or in older zooecia; lateral walls well developed, septular pores in gymnocystal lateral walls large and surrounded by a distinct cryptocystal area, lateral ones usually transversely oval in outline, distal pore suborbicular, very slightly raised relative to lateral ones.

Orifice oval with a fairly straight and narrow proximal margin, slightly longer than wide, broadest in distal third, proximal third delimited by a pair of short and thick, blunt condyles oriented proximomedially; distolateral orifice margins with six short and closely-spaced spines arranged in two groups of three with a distinct distal gap, spine bases thick (Fig. 2C).

Ovicell hyperstomial, ooecium barely touching frontal shield of distal zooid or raised well above substratum when formed at colony margin, globular, with a short tubular proximal peristome wedged in between distalmost pair of spines and terminating at distal orifice margin, in general very little longer than wide; ectooecium smooth, encompassing lower half of ooecium; endooecium accordingly wellexposed, hemispherical, surface structure irregular, with an indistinct reticulate or nodular pattern; ooecial aperture taller than wide, acleithral (Figs 1C, 2B, D).

Ancestrula tatiform, almost oval in outline (ca $300 \mu \mathrm{m}$ long, $190 \mu \mathrm{m}$ wide), widest in proximal third, gymnocyst narrow and steeply sloping all around zooid except for proximal part, in which it is slightly better developed and more gently sloping, cryptocyst extremely reduced and only present at proximolateral margin, opesia extensive (ca $220 \mu \mathrm{m}$ long, $150 \mu \mathrm{m}$ wide), pyriform, distinctly constricted in distal third, surrounded by nine spines arranged in four closely positioned distal spines and five more widely spaced proximal ones; a single first-generation autozooid budded distally or distolaterally (Fig. 2E-F).

\section{Remarks}

Atlantisina atlantis gen. et sp. nov. occurs on the central NE Atlantic seamount complex together with A. meteor gen. et sp. nov. (see below), and both are also morphologically similar. The latter differs from the former in having eight instead of six oral spines, and in that the endooecial surface is more markedly nodular and similar to the zooecial frontal shield. In contrast, the endooecium in A. atlantis gen. et sp. nov. is less conspicuously and variably structured (faint ridges or nodules), and often even lacking any apparent structure (e.g., Fig. 1C), being reminiscent of the early ontogenetic patterning of the frontal shield before the flattened nodules are formed. In some cases, however, a vague pattern of honeycomb depressions is visible, which is similar to the endooecial structure of several species found on or near the continental shelf (see below).

Another species with similar autozooids is Atlantisina inarmata gen. et sp. nov. from the Canary Islands (see below), which differs only in having slightly larger zooids and in that its skeleton is porcelain white, whereas it is translucent in A. atlantis gen. et sp. nov. A further important difference is found in the surface structure of the endooecium, which is densely and deeply pitted in A. inarmata gen. et sp. nov. The ooecium is also larger, and particularly wider, than in A. atlantis gen. et sp. nov.

\section{Ecology}

The sampled colonies of Atlantisina atlantis gen. et sp. nov. predominantly encrust coral skeletons, forming small patches or exploiting the surface via bi- or triserial ribbons. They have been found at depths between 275 and $460 \mathrm{~m}$.

\section{Distribution}

The species is apparently endemic to Atlantis Smt in the central North Atlantic. 
BERNING B. et al., New bathyal Bryozoa from the NE Atlantic

\section{Atlantisina meteor gen. et sp. nov. urn:1sid:zoobank.org:act:F9928F6E-D74B-47B5-B985-CAC2BB62ED51}

Figs 1B, 3A-F, Table 3

\section{Diagnosis}

Frontal shield densely covered by relatively small, irregularly shaped nodules with flattened tips; lateral walls very well developed, septular pores very large, round to elongate transversely oval; distolateral margin of orifice with eight (or rarely nine) slender oral spines, condyles short, blunt and thickened, no suboral mucro. Ectooecium covering more or less the lower half of ooecium; exposed endooecium relatively large and hemispherical, surface topography generally as frontal shield but nodular pattern not as pronounced. Ancestrula presumably with nine spines grouped in five widely spaced proximal ones and four closely spaced distal ones, opesia slightly constricted in distal third, cryptocyst practically absent.

\section{Etymology}

Named after its type locality, the Great Meteor Bank; used as a noun in apposition.
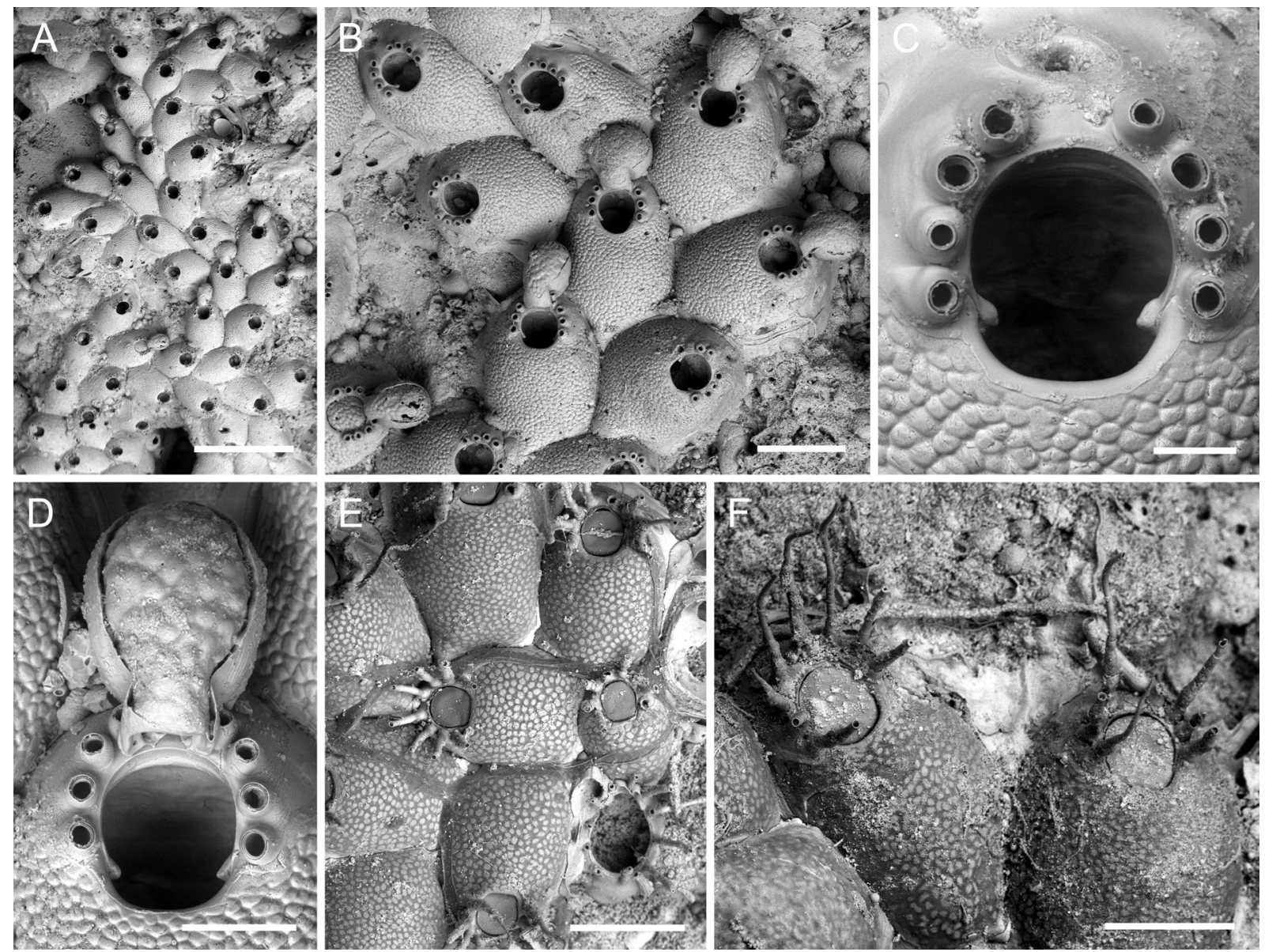

Fig. 3. Atlantisina meteor gen. et sp. nov., Great Meteor Bank A. Overview of holotype (OLL 2016/130a). B. Several autozooids and ovicellate zooids (holotype OLL 2016/130a). C. Orifice (paratype MNHNIB-2014-50). D. Ooecium (holotype OLL 2016/130a). E. Periancestrular region (SMF 40.040). F. Unbleached autozooids with typical whip-like spines (paratype OLL 2016/133a). Scale bars: $\mathrm{A}=1 \mathrm{~mm} ; \mathrm{B}=300 \mu \mathrm{m} ; \mathrm{C}=50 \mu \mathrm{m} ; \mathrm{D}=100 \mu \mathrm{m} ; \mathrm{E}-\mathrm{F}=200 \mu \mathrm{m}$. 
Table 3. Measurements of Atlantisina meteor gen. et sp. nov.

\begin{tabular}{ccccccc}
\hline & ZL & ZW & OL & OW & OvL & OvW \\
\hline Mean & 561 & 357 & 122 & 115 & 206 & 186 \\
SD & \pm 55 & \pm 44 & \pm 9 & \pm 7 & \pm 25 & \pm 8 \\
$\#$ & 17 & 17 & 13 & 13 & 4 & 4 \\
\hline
\end{tabular}

\section{Holotype}

GREAT METEOR BANK: 2 colonies on limestone, the larger one with eight ovicells is the holotype (OLL 2016/130a), the smaller colony without ovicells is the paratype (OLL 2016/130b), bleached, Stn 20.

\section{Paratypes}

GREAT METEOR BANK: 4 colonies on limestone ( 2 with ovicells, 1 with ancestrula), unbleached, Stn 20 (MNHN-IB-2014-50); 2 colonies on limestone (1 with ancestrula, 1 with ovicells), unbleached, Stn 20 (MNHN-IB-2014-51); 1 colony with ancestrula on limestone, unbleached, Stn 20 (MNHNIB-2014-52); 1 colony on Cladocora debilis Milne Edwards \& Haime, 1849, mounted on stub and sputter-coated, Stn 21 (OLL 2016/131); 1 colony with ancestrula and ovicells on coral base, unbleached, Stn 20 (OLL 2016/132); 2 colonies on limestone, unbleached, Stn 20 (OLL2016/133); 1 colony on bioclast, mounted on stub and sputter-coated, Stn 20 (SMF 40.039); 4 colonies (2 with ancestrula) on limestone, unbleached, Stn 20 (SMF 40.040); 1 colony with ovicells on limestone, bleached, Stn 20 (SMF 40.041).

\section{Other material examined}

GREAT METEOR BANK: 10 colonies on Anomocora fecunda (Pourtalès, 1871), Stn 19 (unregistered MNHN material); 1 tiny colony on biogenic debris, sputter-coated, Stn 23 (unregistered MNHN material); 1 colony on C. debilis, mounted on stub and sputter-coated, Stn 21 (OLL 2015/10); 1 colony on C. debilis, mounted on stub and sputter-coated, Stn 19 (OLL 2016/134); 3 zooids (interior frontal shield), mounted on stub and sputter-coated, Stn 20 (OLL 2016/135); several colonies on C. debilis skeletons, unbleached, Stn 21 (OLL 2016/136); numerous colonies on limestone, unbleached, Stn 20 (OLL 2016/137).

IRVING SMT: 2 colonies on small rocks, 3 colonies on Flabellum chunii Marenzeller, 1904, Stn 31 (unregistered MNHN material); 5 colonies on small rocks, Stn 32 (unregistered MNHN material); 12 colonies on small rocks (1 sputter-coated) plus 4 colonies on F. chunii, Stn 33 (unregistered MNHN material); 1 colony on stylasterid skeleton, Stn 34 (unregistered MNHN material).

HYÈRES SMT: 3 colonies on $F$. chunii, Stn 26 (unregistered MNHN material); 1 small colony on old shell, Stn 27 (unregistered MNHN material); 1 colony on $F$. chunii and 5 small colonies on shell fragments (one sputter-coated), Stn 28 (unregistered MNHN material); 1 colony on F. chunii, Stn 29 (unregistered MNHN material); 3 colonies on F. chunii, Stn 30 (unregistered MNHN material); 1 colony on rock fragment, Stn 25 (unregistered MNHN material); 1 colony on bioclast, mounted on stub and sputter-coated, Stn 28 (OLL 2016/138); 1 colony on bioclast, mounted on stub and sputter-coated, Stn 28 (OLL 2016/139).

\section{Description}

Colony encrusting, unilaminar, forming small patches and bi- to triserial ribbons (Fig. 3A). Zooecia oval to polygonal, with tapering proximal end wedged in between proximal zooecia, separated by deep grooves (Fig. 3B). Frontal shield matted vitreous, convex, surface densely covered with relatively small irregular and flattened nodules, imperforate except for some six to eight very small marginal pores, invisible in frontal view or in older zooecia; lateral walls particularly well developed, septular pores in 
lateral walls very large and transversely oval, surrounded by a broad area of nodular cryptocyst, distal pore suborbicular, slightly raised relative to lateral ones (Fig. 1B).

Orifice almost as wide as long, broadest in distal third, proximal and lateral margins fairly straight, proximal third delimited by a pair of very short and thick, blunt condyles oriented proximomedially (Fig. 3C); lateral and distolateral margins with eight (very rarely nine) closely-spaced, slender, tapering and slightly curved spines with thick cylindrical bases (Fig. 3C, F), arranged in two groups of four with a distinct distal gap (in case there are nine spines, one group consists of five); all eight spines present in ovicellate zooids, with the distalmost pair thinner and tightly pressed against the ooecial peristome (Fig. 3D).

Ovicell hyperstomial, ooecium barely resting on distal zooid's frontal shield (Fig. 3B, D), globular, about as long as wide, with a short tubular peristome wedged in between distalmost pair of spines and terminating at distal orifice margin; ectooecium smooth, encompassing approximately lower half of ooecium; exposed endooecium relatively large, hemispherical, surface covered by flattened irregular nodules similar to frontal shield (Fig. 3D); ooecial aperture suborbicular, about as tall as wide, acleithral.

Ancestrula oval (ca $280 \mu \mathrm{m}$ long, $210 \mu \mathrm{m}$ wide), tatiform, gymnocyst well-developed and gently sloping proximally, becoming steeper and narrower distally; cryptocyst practically absent; opesia oval (ca $185 \mu \mathrm{m}$ long, $140 \mu \mathrm{m}$ wide), slightly constricted in distal third; presumably nine mural spines, with five proximal ones widely spaced and four distal ones situated closer together; a single first-generation autozooid budded distally or distolaterally (Fig. 3E).

\section{Remarks}

Atlantisina meteor gen. et sp. nov. is the only species in the genus with eight or occasionally even nine spines surrounding the orifice (all other species have six), and in which the number of spines may occasionally vary. The additional spine is usually thinner and wedged in between the four others on one side of the orifice. Besides this difference in spine number, A. meteor gen. et sp. nov. is very similar to $A$. atlantis gen. et sp. nov., which occurs on the relatively closely located Atlantis Smt (ca $150 \mathrm{~km}$ north of the Great Meteor Bank-Hyères-Irving seamount complex), and also to A. inarmata gen. et sp. nov. from the Canary Islands (see below). However, the nodules on the frontal shield in A. meteor gen. et sp. nov. are slightly smaller and more irregular in outline. Moreover, the surface structure of the endooecium is similar to that of the frontal shield, while it is more indistinctly and variably sculptured in A. atlantis gen. et sp. nov., and deeply pitted in A. inarmata gen. et sp. nov.

Besides the Great Meteor Bank, A. meteor gen. et sp. nov. has also been recorded from the relatively closely located Irving and Hyères seamounts. These three discrete populations differ slightly in the size of their frontal shield nodules, and also in the nodular pattern on the endooecial surface, which may be variably pronounced. However, these differences are very subtle and may also occur within colonies. We thus regard these differences as representing intraspecific variability until genetic analyses can be carried out.

\section{Ecology}

The bi- to triserial colonies of this species encrust coral and stylasterid skeletons, shells and pebbles at depths between 270 and $750 \mathrm{~m}$.

\section{Distribution}

Atlantisina meteor gen. et sp. nov. occurs on the central Atlantic Great Meteor Bank and probably also on Irving Smt and Hyères Smt. 


\section{Atlantisina inarmata gen. et sp. nov. urn:1sid:zoobank.org:act:BDF79949-1519-48E1-81DF-12B922AE7D25}

Fig. 4A-F, Table 4

\section{Diagnosis}

Frontal shield porcelain white, markedly convex, surface densely covered by large flattened nodules, up to eight tiny marginal pores; lateral walls well developed, septular pores large, round to transversely oval; orifice margin with six oral spines, condyles short and narrow, occasionally slightly thickened distally, operculum yellowish; no suboral mucro. Ooecium as long as wide; ectooecium covering slightly more than the lower half of ooecium; exposed endooecium relatively large and hemispherical, surface densely covered by numerous closely spaced and deep pits separated by thickened ridges. Ancestrula with nine spines separated into two groups of five widely spaced proximal and four closely spaced distal spines, opesia pyriform, cryptocyst a narrow proximal band thinning distally.
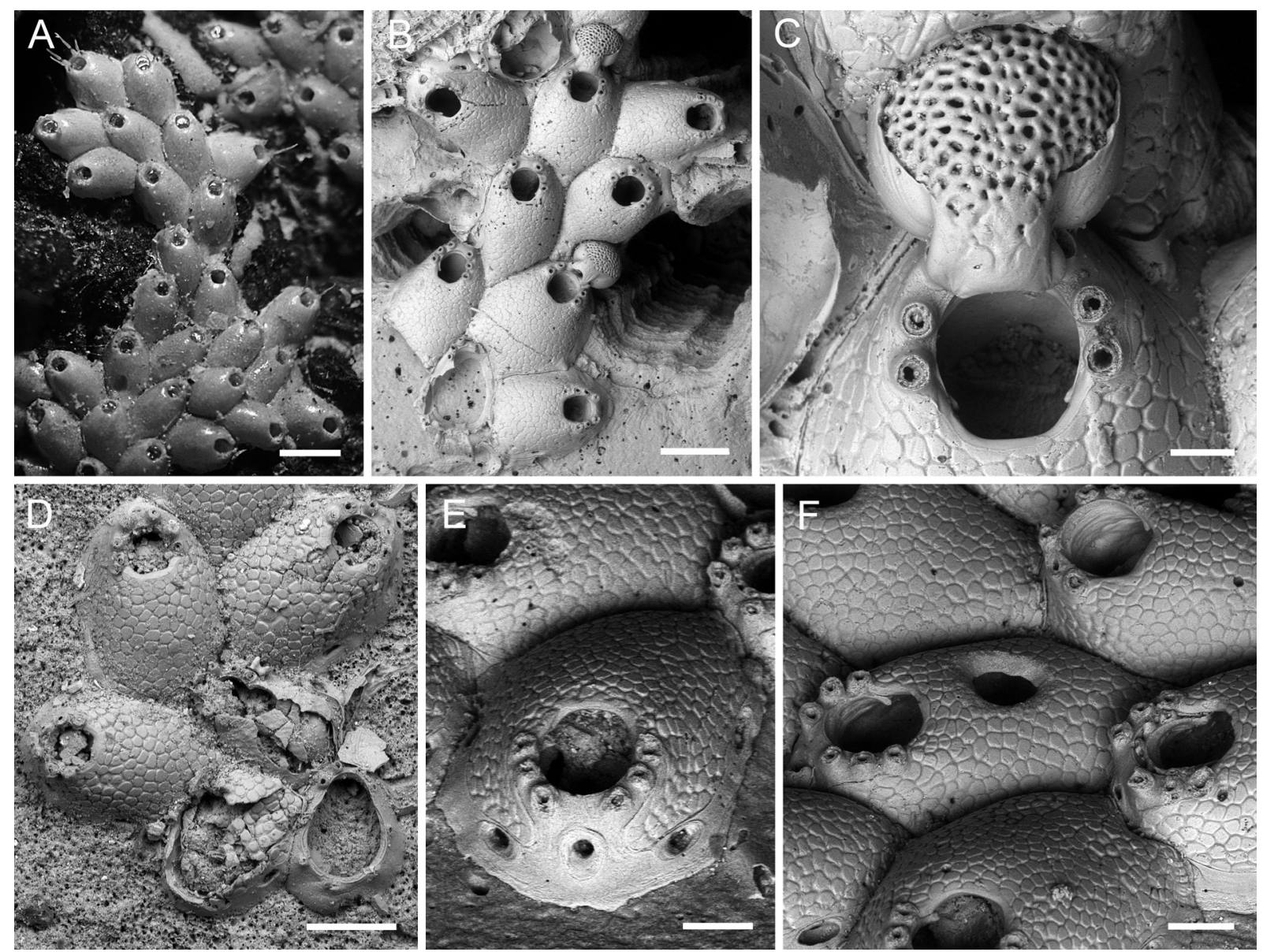

Fig. 4. Atlantisina inarmata gen. et sp. nov. Canary Islands. A. Overview of holotype, optical image (MNHN-IB-2014-53). B. Several autozooids and ovicellate zooids (paratype MNHN-IB-2014-55). C. Close-up of the orifice and the deeply pitted ooecium (paratype MNHN-IB-2014-55). D. Periancestrular region (paratype OLL 2016/140). E. An autozooid at the colony growth margin (paratype MNHN-IB-2014-54). F. An autozooid with a borehole in the frontal shield (centre), and one with an intramural bud (at right), indicated by the presence of a secondary orifice rim (paratype MNHNIB-2014-54). Scale bars: A $=500 \mu \mathrm{m} ; \mathrm{B}=300 \mu \mathrm{m} ; \mathrm{C}=50 \mu \mathrm{m} ; \mathrm{D}=200 \mu \mathrm{m} ; \mathrm{E}, \mathrm{F}=100 \mu \mathrm{m}$. 
Table 4. Measurements of Atlantisina inarmata gen. et sp. nov.

\begin{tabular}{ccccccc}
\hline & ZL & ZW & OL & OW & OvL & OvW \\
\hline Mean & 600 & 392 & 137 & 125 & 230 & 232 \\
SD & \pm 62 & \pm 47 & \pm 6 & \pm 6 & - & \pm 4 \\
$\#$ & 30 & 30 & 25 & 25 & 2 & 4 \\
\hline
\end{tabular}

\section{Etymology}

The name refers to the absence of a protective suboral mucro, in contrast to the other species occurring in the nearshore seamounts and the continental slope.

\section{Material examined}

\section{Holotype}

CANARY ISLANDS: 1 large colony (> 50 autozooids), on rock, Stn 10 (MNHN-IB-2014-53).

\section{Paratypes}

CANARY ISLANDS: 7 colonies on skeleton, Stn 9 (MNHN-IB-2014-54); 1 ovicellate colony on biogenic substrate, Stn 9 (MNHN-IB-2014-55); 1 young colony with ancestrula, on echinid test, Stn 9 (OLL 2016/140); 1 colony on rock, Stn 11 (MNHN-IB-2014-56).

\section{Other material examined}

CANARY ISLANDS: 10 colonies on small rocks, shells and other biogenic substrata, Stn 9 (unregistered MNHN material); 7 colonies on small rocks, Stn 9 (OLL 2016/141); 3 colonies on rock, Stn 11 (OLL 2016/142); 1 small colony with ancestrula on limestone, unbleached, Stn 11 (OLL 2016/143).

\section{Description}

Colony encrusting, unilaminar, forming small irregular patches or biserial to triserial branching ribbons (Fig. 4A). Zooecia oval to polygonal, with proximal ends tapering and wedged in between proximal zooecia (Fig. 4B). Frontal shield translucent, very convex, densely covered by relatively large, closelyspaced, flattened nodules (Fig. D, F), imperforate except for up to eight minute marginal pores that may be difficult to detect in frontal view or in older zooecia; lateral walls well developed, septular pores large and surrounded by a distinct cryptocystal area, lateral ones usually transversely oval, slightly raised distal pore suborbicular (Fig. 4E).

Orifice a little longer than wide, with a rounded and broader anter and a fairly straight and narrower proximal margin delimited by a pair of very short, blunt and occasionally distally thickened condyles directing proximomedially (Fig. 4C); distolateral orifice margins with six closely-spaced spines with thick bases, arranged in two groups of three with a distinct distal gap (Fig. 4E).

Ovicell hyperstomial, ooecium barely resting on frontal shield of distal zooid, globular with a short tubular proximal peristome wedged in between distalmost pair of spines and terminating at distal orifice margin, about as long as wide; ectooecium smooth, encompassing slightly more than lower half of ooecium; exposed endooecium relatively large, hemispherical, densely covered by numerous deep pits that give it a perforate appearance (Fig. 4C); ooecial aperture about as tall as wide.

Ancestrula tatiform, broadly oval (ca $320 \mu \mathrm{m}$ long, $260 \mu \mathrm{m}$ wide), widest at about mid-distance, gymnocyst relatively well developed all around, gently sloping all around, becoming slightly narrower and steeper distally, cryptocyst forming only a very narrow rim around proximal half of opesia, opesia extensive (ca $215 \mu \mathrm{m}$ long, $150 \mu \mathrm{m}$ wide), pyriform, distinctly constricted in distal third, surrounded by 
nine spines arranged in four closely positioned distal spines and five more widely spaced proximal ones; a single first-generation autozooid budded distally or distolaterally (Fig. 4D).

\section{Remarks}

The autozooids of Atlantisina inarmata gen. et sp. nov. are very similar to those of A. atlantis gen. et sp. nov. when observed under the SEM. When observed under a binocular microscope, however, the frontal shield of the former is porcelain-white while that of the latter is rather translucent. Moreover, the ovicells are distinctly different, with $A$. inarmata gen. et sp. nov. having a deeply and densely pitted endooecial surface structure, while it is rather faint and irregular in A. atlantis gen. et sp. nov. The zooids, orifices and ovicells are also larger in $A$. inarmata gen. et sp. nov. than in A. atlantis gen. et sp. nov. (see Table 1). Nevertheless, the similarity in autozooidal morphology is remarkable given the distance of ca $1500 \mathrm{~km}$ between Atlantis Smt and the Canary Islands.

\section{Ecology}

The bi- to triserial colonies of $A$. inarmata gen. et sp. nov. encrust empty shells, dead skeletons and small rocks at depths between 345 and $485 \mathrm{~m}$. Some zooidal frontal shields show bevelled boreholes (Fig. 4F), which were presumably drilled by predatory microgastropods, while others are damaged around the orifice, and intramural buds occur in damaged or undamaged zooecia (cf. Berning 2008). The relatively high percentage of damaged and repaired zooids may be related to the lack of defensive structures around the orifice apart from oral spines, which characterise all other species from nearshore seamounts and the continental slope described below.

\section{Distribution}

Restricted to the island of Gran Canaria (Canary Islands).

Atlantisina seinensis gen. et sp. nov. urn:1sid:zoobank.org:act:E78F78F3-3E20-4F34-98E9-20441E929E45

Fig. 5A-E, Table 5

\section{Diagnosis}

Frontal shield densely covered by relatively large, flattened nodules; lateral walls well developed, septular pores large, round to elongated oval, surrounded by a broad area of cryptocystal calcification; orifice margin with six oral spines; a single, large, pointed mucro with a broad base along the proximal orifice margin is positioned suborally. Ooecium longer than wide; ectooecium covering approximately the lower half of ooecium; exposed endooecium oval, convex, surface densely covered by numerous deep pits bounded by thickened ridges.

\section{Etymology}

Named after its type locality, Seine Smt.

\section{Material examined}

\section{Holotype}

SEINE SMT: 1 coated colony on biogenic concretion, Stn 42 (MNHN-IB-2014-57).

\section{Paratypes}

SEINE SMT: 1 colony on small rock, Stn 41 (MNHN-IB-2014-58); 3 small colonies (2 ovicellate, 1 immature) on small rock, Stn 42 (MNHN-IB-2014-59); 1 colony on limestone, Stn 41 (OLL 2016/144). 
BERNING B. et al., New bathyal Bryozoa from the NE Atlantic

Table 5. Measurements of Atlantisina seinensis gen. et sp. nov.

\begin{tabular}{ccccccc}
\hline & ZL & ZW & OL & OW & OvL & OvW \\
\hline Mean & 501 & 329 & 119 & 106 & 203 & 145 \\
SD & \pm 49 & \pm 54 & \pm 6 & \pm 6 & \pm 5 & \pm 11 \\
$\#$ & 13 & 13 & 5 & 5 & 4 & 4 \\
\hline
\end{tabular}

\section{Description}

Colony encrusting, unilaminar, forming small patches and/or bi- to triserial ribbons (Fig. 5A). Zooecia oval to polygonal, with tapering proximal end(s) wedged in between proximal zooecia, separated by deep grooves (Fig. 5A). Frontal shield convex, surface densely covered by relatively large, round to polygonal, flattened nodules (Fig. 5B-C), imperforate except for a few very small marginal pores, invisible in frontal view or in older zooecia; suboral frontal shield steeply raised to form a massive mucro with a pointed tip (Fig. 5B-C), lateral and distal part made of gymnocystal calcification, proximal face a continuation of nodular cryptocystal-type calcification of frontal shield, broad base of mucro framing proximal orifice margin and levelling towards proximal pair of spines; lateral walls well developed,
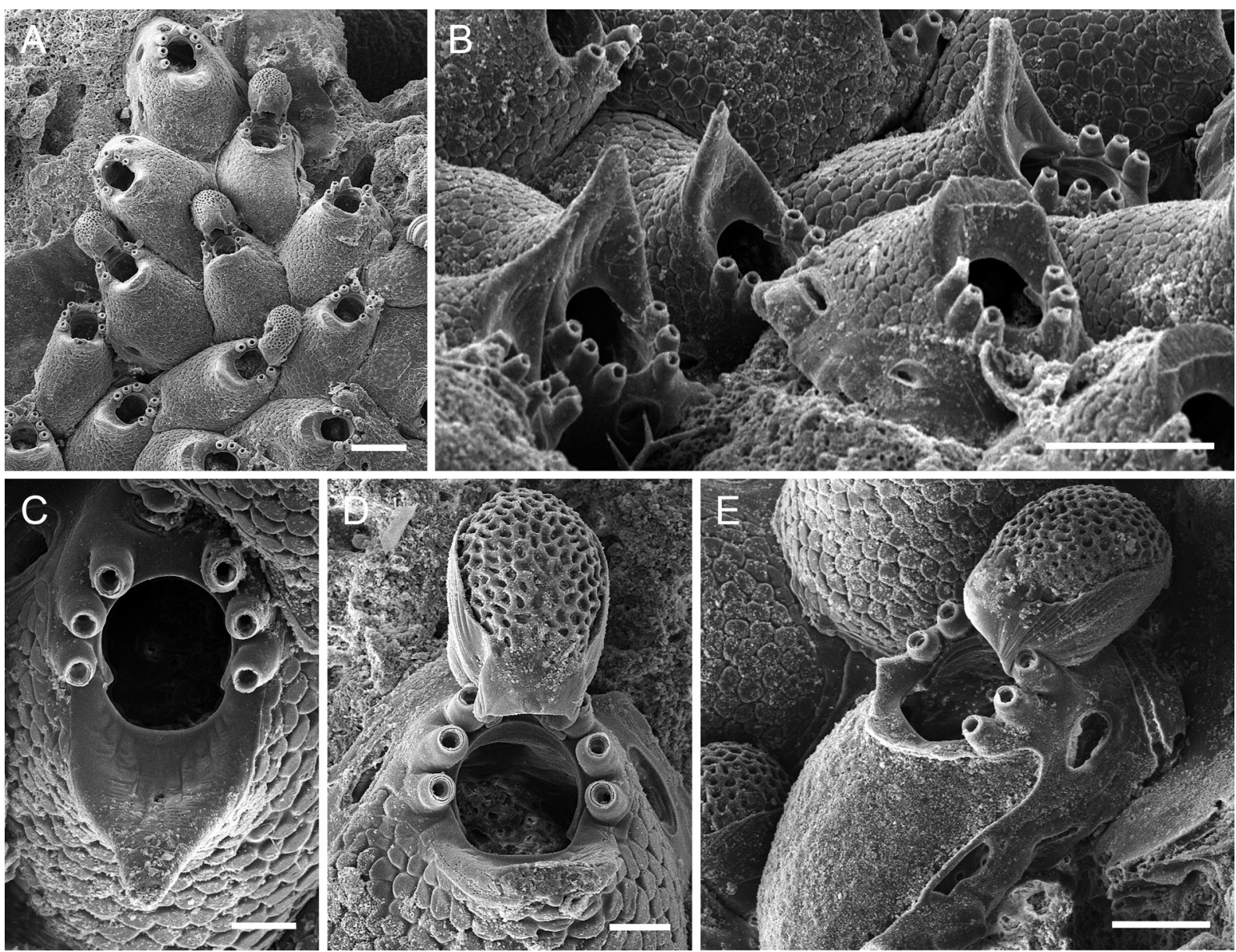

Fig. 5. Atlantisina seinensis gen. et sp. nov., Seine Smt, holotype (MNHN-IB-2014-57). A. Autozooids and ovicellate zooids. B. Lateral view showing the vertical dimensions of the suboral umbones. C. Orifice. D. Ooecium. E. Early ontogenetic zooid with a fully formed ooecium. Scale bars: A-B = $200 \mu \mathrm{m} ; \mathrm{C}-\mathrm{D}=50 \mu \mathrm{m} ; \mathrm{E}=100 \mu \mathrm{m}$. 
septular pores relatively large, round to transversely oval, each pore surrounded by a broad cryptocystal area with an irregular surface (Fig. 5B, D-E).

Orifice suborbicular to oval, slightly longer than wide, broadest at about mid-distance, proximal orifice margin slightly concave, poster comprising about one-third of entire orifice length, delimited from anter by a pair of very short and thick, blunt condyles directing proximomedially (Fig. 5C); lateral and distolateral margins with six closely-spaced spines with thick bases, arranged in two groups of three with a distinct distal gap (Fig. 5B-C); all six spines present in ovicellate zooids with distal pair a little thinner and resting firmly against proximolateral sides of ooecial peristome (Fig. 5D).

Ovicell hyperstomial, ooecium barely resting on frontal shield of distal zooid or free at colony margin, globular, distinctly longer than wide and with a short tubular peristome opening at distal orifice margin, ooecial aperture suborbicular, acleithral; a broad band of smooth ectooecial cover encompassing slightly more than the lower half of ooecium; endooecial surface densely covered by numerous, irregularly shaped, deep pits bounded by thick ridges, giving false appearance of a pseudoporous endooecium (Fig. 5D-E).

An ancestrula was not observed.

\section{Remarks}

Atlantisina seinensis gen. et sp. nov. is easily distinguished from all other species of Atlantisina gen. nov. owing to its single tall, triangular suboral mucro. Concerning frontal shield morphology, this species takes an intermediate position: whereas A. atlantis gen. et sp. nov., A. meteor gen. et sp. nov. and A. inarmata gen. et sp. nov. have the same type of nodular frontal calcification but lack a suboral mucro, all remaining Atlantisina gen. nov. species (see below) have complex mucrones but frontal shields with a honeycomb structure. The densely and deeply pitted endooecium in A. seinensis gen. et sp. nov. is, again, shared with $A$. inarmata gen. et sp. nov. from the Canary Islands.

\section{Ecology}

As in the other Atlantisina gen. nov. species, colonies of $A$. seinensis gen. et sp. nov. are small, combining spot- and runner-type characters (cf. Bishop 1989), and forming small patches with bi- to triserial ribbons. The colonies were found encrusting rocks at depths of 235-260 m.

\section{Distribution}

This species is known only from Seine Smt.

Atlantisina tricornis gen. et sp. nov. urn:1sid:zoobank.org:act:0DB29D39-154D-4C9D-AF4D-F07E525B850B

Figs 1E, 6A-F, Tables 6-7

Hippoporina sp. - d'Hondt 1974: 46, fig. 6.

Romancheinidae gen. et sp. indet. - Souto et al. 2016: 432.

\section{Diagnosis}

Frontal shield with a reticulate pattern of raised ridges around polygonal depressions; aperture with six oral spines; orifice suborbicular, proximal edge fairly straight or slightly concave, condyles short, blunt, tip somewhat thickened; suboral area with three tall thick mucrones with pointed tips, occasionally branching from their base or with bifid tips, most often with a central, vertically oriented mucro that is occasionally paired, and two mucrones proximolateral to orifice that are slightly curved and point outwards or are vertically oriented. Ooecium as long as wide or occasionally laterally compressed; 
ectooecium well developed, approximately covering two-thirds or more of entire ooecium; exposed endooecium relatively small, occasionally reduced to an elongated central area, surface topography similar to that of frontal shield, but usually with smaller depressions and steeper ridges. Ancestrula with nine spines, the distal four more closely spaced than (and slightly offset from) the proximal five spines, opesia slightly constricted in distal fourth, cryptocyst practically absent.

\section{Etymology}

Named for its prominent tridentate suboral mucro.

\section{Material examined}

\section{Holotype}

N IBERIAN SLOPE: 1 large ovicellate colony on biogenic substratum (plus another smaller colony), Stn 39 (MNHN-IB-2014-60).
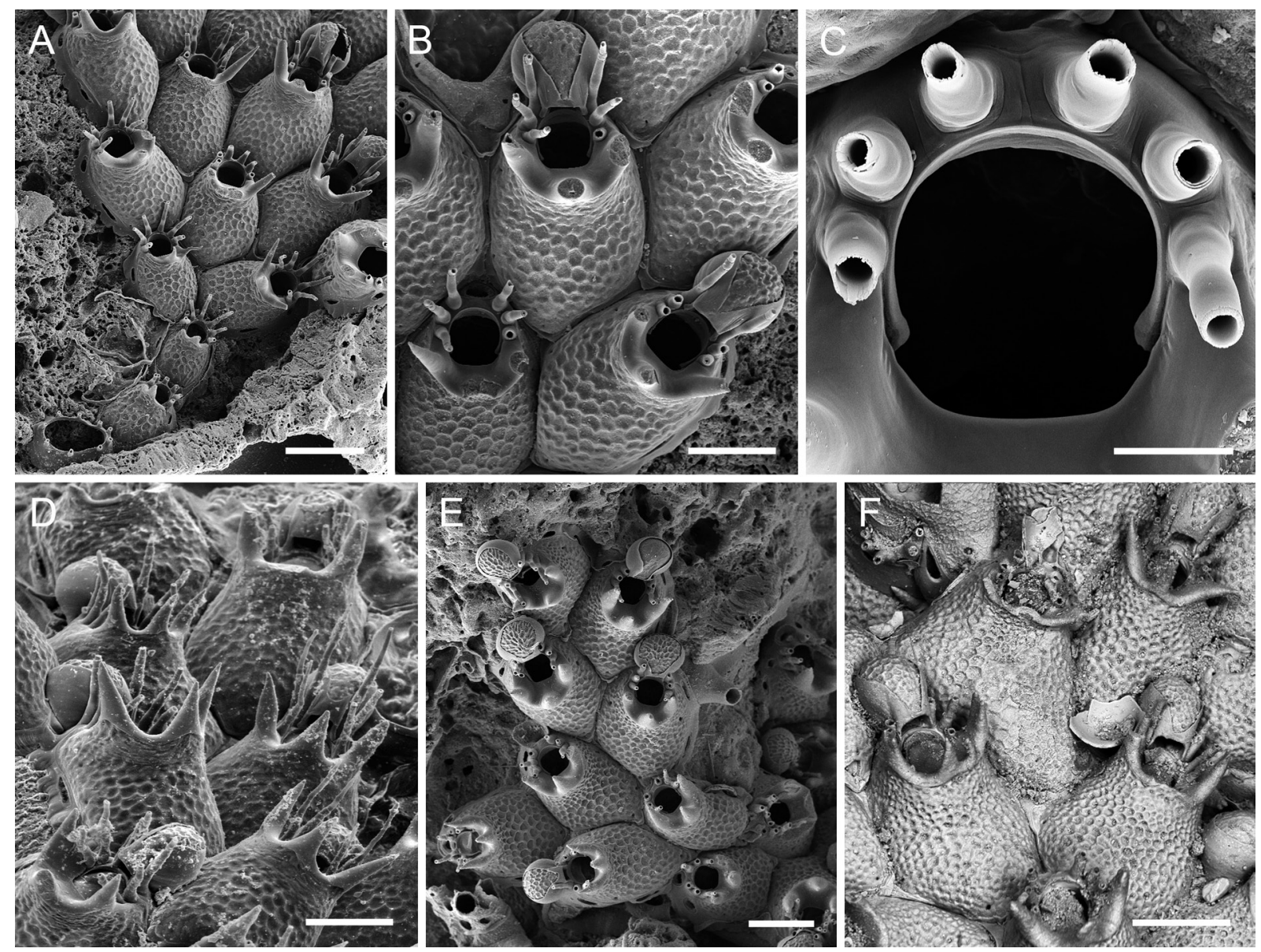

Fig. 6. Atlantisina tricornis gen. et sp. nov. A. Early colony development; note the presence of the maternal 5th-generation autozooid at centre right (paratype MNHN-IB-2014-64, N Iberian slope). B. Ovicellate zooids (paratype MNHN-IB-2014-65, N Iberian slope). C. Close-up of orifice (paratype MNHN-IB-2014-65, N Iberian slope). D. Lateral view of suboral crests (holotype MNHN-IB-2014-60, N Iberian slope). E. Colony from Galicia Bank forming biserial ribbons; note the relatively broad ooecia (MNHN-IB-2014-279). F. Colony from the W Iberian slope (photo taken by J. Souto); note the bifid tips in some of the mucrones (zooid at lower left) while other suboral crests (zooid at top right) have a simple trident (MNHN-IB-2008-7194). Scale bars: A, E-F $=300 \mu \mathrm{m} ; \mathrm{B}, \mathrm{D}=200 \mu \mathrm{m} ; \mathrm{C}=50 \mu \mathrm{m}$. 
Table 6. Measurements of Atlantisina tricornis gen. et sp. nov. from Galicia Bank population GAL1.

\begin{tabular}{ccccccc}
\hline & ZL & ZW & OL & OW & OvL & OvW \\
\hline Mean & 584 & 394 & 122 & 121 & 207 & 213 \\
SD & \pm 32 & \pm 66 & \pm 7 & \pm 5 & \pm 15 & \pm 16 \\
$\#$ & 16 & 16 & 11 & 11 & 16 & 16 \\
\hline
\end{tabular}

\section{Paratypes}

N IBERIAN SLOPE: 2 colonies on Lophelia pertusa (Linnaeus, 1758), Stn 38 (MNHN-IB-2014-61); 5 colonies on a fragment of coral skeleton, Stn 39 (MNHN-IB-2014-63); 1 coated ovicellate colony with ancestrula, Stn 39 (MNHN-IB-2014-64); 1 coated ovicellate colony, Stn 39 (MNHN-IB-2014-65).

LE DANOIS BANK: 1 colony on Balanophyllia thalassae Zibrowius, 1980, Stn 35 (MNHN-IB-2014-62).

GALICIA BANK: 1 coated colony, Stn 15 (MNHN-IB-2014-279).

\section{Other material examined}

N IBERIAN SLOPE: 2 colonies on old L. pertusa skeleton, Stn 37 (unregistered MNHN material); 2 colonies on coral skeletons, Stn 39 (unregistered MNHN material); 2 colonies on coral skeleton, Stn 40 (unregistered MNHN material); 15 colonies on fragmented coral skeletons, Stn 39 (OLL 2016/145).

GALICIA BANK: several colonies identified as Romancheinidae gen. et sp. indet. by Souto et al. (2016), Stn 13 (MNCN 25.03/3955); 1 colony on coral, Stn 14 (unregistered MNHN material); 4 colonies on rock, Stn 15 (unregistered MNHN material); 3 colonies on rock, Stn 16 (unregistered MNHN material).

W IBERIAN SLOPE: 2 colonies, identified as Hippoporina sp. by d'Hondt (1974), Stn 44 (MNHNIB-2008-7194).

\section{Description}

Colony encrusting, unilaminar, forming small patches and bi- to triserial ribbons (Fig. 6E). Zooecia polygonal or oval, with tapering proximal end(s) wedged in between proximal zooecia, separated by deep grooves (Fig. 6A-B). Frontal shield convex, distally steeply raised to form a suboral crest, surface with a reticulate pattern of raised ridges around polygonal depressions (Fig. 6B), imperforate except for a few small marginal pores hardly visible in frontal view or in older zooecia; suboral crest usually with three widely spaced and thickly calcified conical mucrones with acuminate tips (Fig. 6D), the mucrones either directed vertically (Fig. 6E) or diverging outwards (Fig. 6F), occasionally one or all mucrones have bifid tips and/or there may be a pair of central mucrones (Fig. 6F); all mucrones rising from a prominent broad area of smooth gymnocystal calcification that slopes towards proximal orifice margin, then narrowing distally and abutting proximal pair of spines; lateral wall moderately well developed, septular pores transversely oval to elongate, area surrounding pores reduced, distal pore large, suborbicular.

Orifice suborbicular, proximal border fairly straight to slightly concave, widest in distal third, proximal third delimited by a pair of very short blunt condyles with slightly thickened tips (Fig. 6C); lateral and distolateral margins with six spines arranged in two series of three, separated by a distinct distal gap (Fig. 6D), spines up to some $350 \mu \mathrm{m}$ long, comprising a thick tubular base ( $80-85 \mu \mathrm{m}$ high) and a thinner whip-like part (200-260 $\mu \mathrm{m}$ long); all 6 spines present in ovicellate zooids, with distal pair abutting proximolateral ooecial wall and wedging in ooecial aperture on both sides. 
Table 7. Morphometric comparison between different populations of Atlantisina tricornis gen. et sp. nov., from the N Iberian slope (NIS), two from Galicia Bank (GAL1, GAL2), and from the W Iberian slope (WIS). All data combined are given under ALL. The measurements are given as the mean \pm standard deviation and the number of measurements taken (in parentheses). The subsequent letter (in bold) represents the results of the intergroup comparison of means using a post hoc Tukey's test; groups not connected by the same letter are significantly different, those with two letters (ab) are not significantly different from $a$ or $b$. See text for further information and the Material section for the remaining abbreviations.

\begin{tabular}{cccccc}
\hline & NIS & GAL1 & GAL2 & WIS & ALL \\
\hline ZL & $614 \pm 37$ & $584 \pm 32$ & $615 \pm 50$ & $645 \pm 64$ & $616 \pm 52$ \\
& $(14) \mathbf{a b}$ & $(16) \mathbf{b}$ & $(29) \mathbf{a b}$ & $(20) \mathbf{a}$ & $(79)$ \\
$\mathrm{ZW}$ & $406 \pm 48$ & $394 \pm 66$ & $398 \pm 38$ & $476 \pm 82$ & $419 \pm 67$ \\
& $(14) \mathbf{b}$ & $(16) \mathbf{b}$ & $(28) \mathbf{b}$ & $(20) \mathbf{a}$ & $(79)$ \\
OL & $135 \pm 6$ & $122 \pm 7$ & $139 \pm 9$ & $156 \pm 9$ & $138 \pm 13$ \\
& $(13) \mathbf{b}$ & $(11) \mathbf{c}$ & $(25) \mathbf{b}$ & $(11) \mathbf{a}$ & $(60)$ \\
OW & $124 \pm 5$ & $121 \pm 5$ & $139 \pm 7$ & $138 \pm 9$ & $132 \pm 10$ \\
& $(18) \mathbf{b}$ & $(11) \mathbf{b}$ & $(25) \mathbf{a}$ & $(11) \mathbf{a}$ & $(65)$ \\
OvL & $226 \pm 18$ & $207 \pm 15$ & $203 \pm 15$ & $233 \pm 18$ & $217 \pm 20$ \\
& $(16) \mathbf{a}$ & $(16) \mathbf{b}$ & $(9) \mathbf{b}$ & $(8) \mathbf{a}$ & $(49)$ \\
OvW & $172 \pm 16$ & $213 \pm 16$ & $177 \pm 8$ & $204 \pm 17$ & $191 \pm 23$ \\
& $(16) \mathbf{b}$ & $(16) \mathbf{a}$ & $(9) \mathbf{b}$ & $(8) \mathbf{a}$ & $(49)$ \\
OvL/W & $1.32 \pm 0.14$ & $0.98 \pm 0.08$ & $1.15 \pm 0.09$ & $1.15 \pm 0.1$ & $1.13 \pm 0.17$ \\
& $(16) \mathbf{a}$ & $(16) \mathbf{c}$ & $(9) \mathbf{b}$ & $(8) \mathbf{b}$ & $(49)$ \\
\hline
\end{tabular}

Ovicell hyperstomial, ooecium barely resting on frontal shield of distal zooid with its proximal part or entirely free at colony margin, globular, about as long as wide or laterally compressed, with a short tubular peristome terminating at distal apertural margin (Fig. 6B, E-F); ectooecium well developed, covering about two-thirds or more of entire ooecium; exposed endooecium of variable size and shape, either pear-shaped and narrowing on peristome when large, or forming a broad central strip when ooecium is compressed, surface topography similar to that of frontal shield but with smaller and marginally elongate depressions and steeper ridges; ooecial aperture about as tall as wide, acleithral.

Ancestrula oval (ca $350 \mu \mathrm{m}$ long, $230 \mu \mathrm{m}$ wide), smooth gymnocyst narrow all around, cryptocyst virtually absent; opesia large, oval to pyriform (ca $235 \mu \mathrm{m}$ long, $145 \mu \mathrm{m}$ wide), slightly constricted in distal fourth; nine spines, with five proximal ones widely spaced and four distal ones situated closer together (Figs 1E, 6A).

\section{Remarks}

Atlantisina tricornis gen. et sp. nov. is the only species of Atlantisina gen. nov. that was recorded from the continental slope while all other species occur on seamounts and near islands. Moreover, it is the only species of Atlantisina gen. nov. that has previously been recorded and figured (d'Hondt 1974; Souto et al. 2016).

Atlantisina tricornis gen. et sp. nov. is clearly distinguished from all other congenerics by its thickly calcified, suboral crest with three pointed mucrones. However, there is some variability in mucro shape and orientation between colonies from the same area, as well as between populations from the three 
sampled regions, the northern Iberian slope, Galicia Bank and the western Iberian slope. For instance, in the Galicia Bank population the three mucrones are usually single, unbranched, straight, and vertically oriented (Fig. 6E), whereas in some zooids the lateral mucrones may be slightly curved outwards and branched, and the central mucro may be twinned. Branching of mucrones was rather frequent in colonies from the continental shelf off northern Portugal (W Iberian slope; Fig. 6F), while in the colonies from the $\mathrm{N}$ Iberian slope the lateral mucrones were constantly unbranched and diverging slightly outwards (Fig. 6A-B, D). However, in some colonies from this region, a secondary acuminate tip may occur laterally on the central mucro. Thus, although the end-members of the mucro-morphotypes are distinctly different, a clear distinction between regions cannot be drawn, as intermediate stages are present.

A certain variability was also detected in the development of the ooecium, whose shape ranges from globular with a large suborbicular area of exposed endooecium (Fig. 6E) to laterally compressed ones in which the endooecium is reduced to a narrow central area (Figs 6B, F). Consequently, ooecium width and the length-width ratio $(\mathrm{OvL} / \mathrm{OvW})$ may differ between colonies. In order to assess the morphological variability between colonies and regions, one-way ANOVA was were performed on the original lengthand width-measurements of zooids, orifices and ooecia. As morphological differences were optically noticeable between colonies occurring in Galicia Bank, the populations were divided into four areagroups, the N Iberian slope (NIS), Galicia Bank 1 (GAL1), Galicia Bank 2 (GAL2), and W Iberian slope (WIS). Statistical analyses of ooecium width data show that, while the mean values are similar within two area-pairs, ooecium width is significantly higher in WIS and GAL1 than in NIS and GAL2 $(\mathrm{F}=24.35, \mathrm{p}<0.001$; see Table 7). Mean values of ooecium length/width ratio of GAL1 (0.98) are significantly different from NIS (1.32), while similar intermediate values (1.15) are observed in WIS and GAL2 colonies. Although distinct differences in size of autozooids and orifices can be perceived between colonies from the four sampled areas (Table 7), statistical analyses do not show a common hierarchy in the four populations when considering the different dimensions (ZL, ZW, OL, OW). Thus, concerning both morphology and morphometry, there is no clear distinction between the populations of the three geographic areas that would allow separating them at the species level.

With their bifid tips and twinned central mucrones (Fig. 6F), some of the zooids in the Portuguese morphotype of A. tricornis gen. et sp. nov. somewhat resemble Atlantisina lionensis gen. et sp. nov. from Lion and Seine seamounts (see below). However, in the latter the mucrones are not as thickly calcified, are positioned on a distinctly raised and relatively straight crest, and the lateral mucrones point distally.

Calcification of the frontal shield's surface in A. tricornis gen. et sp. nov. and the other new species introduced below is the exact opposite of that of $A$. atlantis gen. et sp. nov., A. meteor gen. et sp. nov. and $A$. seinensis gen. et sp. nov. described above. With the reticulate pattern of ridges delimiting round to hexagonal depressions in the former group (Fig. 6B), the precipitation of carbonate seems to be the negative blueprint of the frontally flattened, round to polygonal nodules bounded by grooves in the latter group.

\section{Ecology}

Atlantisina tricornis gen. et sp. nov. has been found at depths between 450 and $1040 \mathrm{~m}$ on the continental slope, and between 675 and $1700 \mathrm{~m}$ on Galicia Bank (see also Souto et al. 2016: table 22, listed as "Species indet."). The species forms small patches and bi- to triserial colonies that encrust rocks and biogenic substrata, mainly coral skeletons but also brachiopods, balanid plates and cidarid spines.

\section{Distribution}

Atlantisina tricornis gen. et sp. nov. was recovered from the continental slope of northern to western Iberia as well as from Galicia Bank. 
BERNING B. et al., New bathyal Bryozoa from the NE Atlantic

\section{Atlantisina lionensis gen. et sp. nov. urn:Isid:zoobank.org:act:54D46F97-6F57-41D2-9417-51DA064B3DF5}

Figs 1A, 7A-D, 8, Table 8

\section{Diagnosis}

Frontal shield with a reticulate pattern of raised ridges around polygonal depressions; orifice suborbicular, condyles short and without thickened tip; suboral region with a broad band of gymnocystal calcification forming a tall, relatively planar or slightly arched crest carrying three to five pointed mucrones of variable size and shape, the central ones shorter and vertically oriented, the two lateral ones longer and directing distolaterally; lateral walls moderately well developed, septular pores transversely oval to very elongate, area surrounding the pores reduced to absent, distal pore comparatively large, suborbicular, slightly raised relative to lateral ones; orifice margin with six oral spines. Ooecium slightly longer than wide; ectooecium relatively broad, covering about two-thirds of ooecium; exposed endooecium relatively small, imperforate, surface topography similar to that of frontal shield but with elongated depressions and steeper ridges; ooecial peristome relatively short. Ancestrula with 11 spines (four oral, seven mural).

\section{Etymology}

Named after its type locality, Lion Smt.

\section{Material examined}

\section{Holotype}

LION SMT: the ovicellate colony marked ' $\mathrm{H}$ ', plus 3 smaller colonies, on a pebble of volcanic rock, Stn 36 (MNHN-IB-2014-66).

\section{Paratypes}

LION SMT: 1 coated colony, Stn 36 (MNHN-IB-2014-67); 2 colonies on a pebble, Stn 36 (MNHNIB-2014-68); 7 colonies and 1 ancestrula on a pebble, Stn 36 (MNHN-IB-2014-69).

\section{Other material examined}

LION SMT: ca 20 colonies on rocks, Stn 36 (unregistered MNHN material); 10 colonies on two pebbles, Stn 36 (OLL 2016/146).

SEINE SMT: 1 colony on limestone, Stn 43 (unregistered MNHN material).

\section{Description}

Colony encrusting, unilaminar, forming small patches and/or bi- to triserial ribbons (Fig. 7A). Zooecia roughly oval, with tapering proximal end(s) wedged in between proximal zooecia, separated by deep grooves. Frontal shield convex, surface with a reticulate pattern of raised ridges around polygonal depressions, imperforate except for a few small (although comparatively conspicuous) marginal pores faintly visible in frontal view (Fig. 1A); a tall, broad and moderately curved or planar suboral crest is formed predominantly by smooth gymnocystal calcification, sloping distolaterally and abutting proximal pair of spines, generally with two long, pointed lateral mucrones directing distolaterally that may occasionally bear tiny secondary mucrones, and one to three smaller central mucrones pointing vertically (Figs 1A, 7B-D); lateral walls moderately well developed laterally, more extensive in distal part, lateral septular pores transversely oval to extremely elongate, area surrounding pores reduced to absent (Figs 1A, 7B-D); distal pore comparatively large, suborbicular and slightly raised relative to lateral ones.

Orifice orbicular, widest at about mid-distance, proximal border fairly straight to slightly concave, proximal third delimited by a pair of short, blunt condyles, tips usually not thickened (Fig. 7B); 
Table 8. Measurements of Atlantisina lionensis gen. et sp. nov.

\begin{tabular}{ccccccc}
\hline & ZL & ZW & OL & OW & OvL & OvW \\
\hline Mean & 565 & 382 & 114 & 125 & 196 & 172 \\
SD & \pm 78 & \pm 57 & \pm 8 & \pm 9 & \pm 20 & \pm 26 \\
$\#$ & 30 & 35 & 14 & 14 & 22 & 22 \\
\hline
\end{tabular}
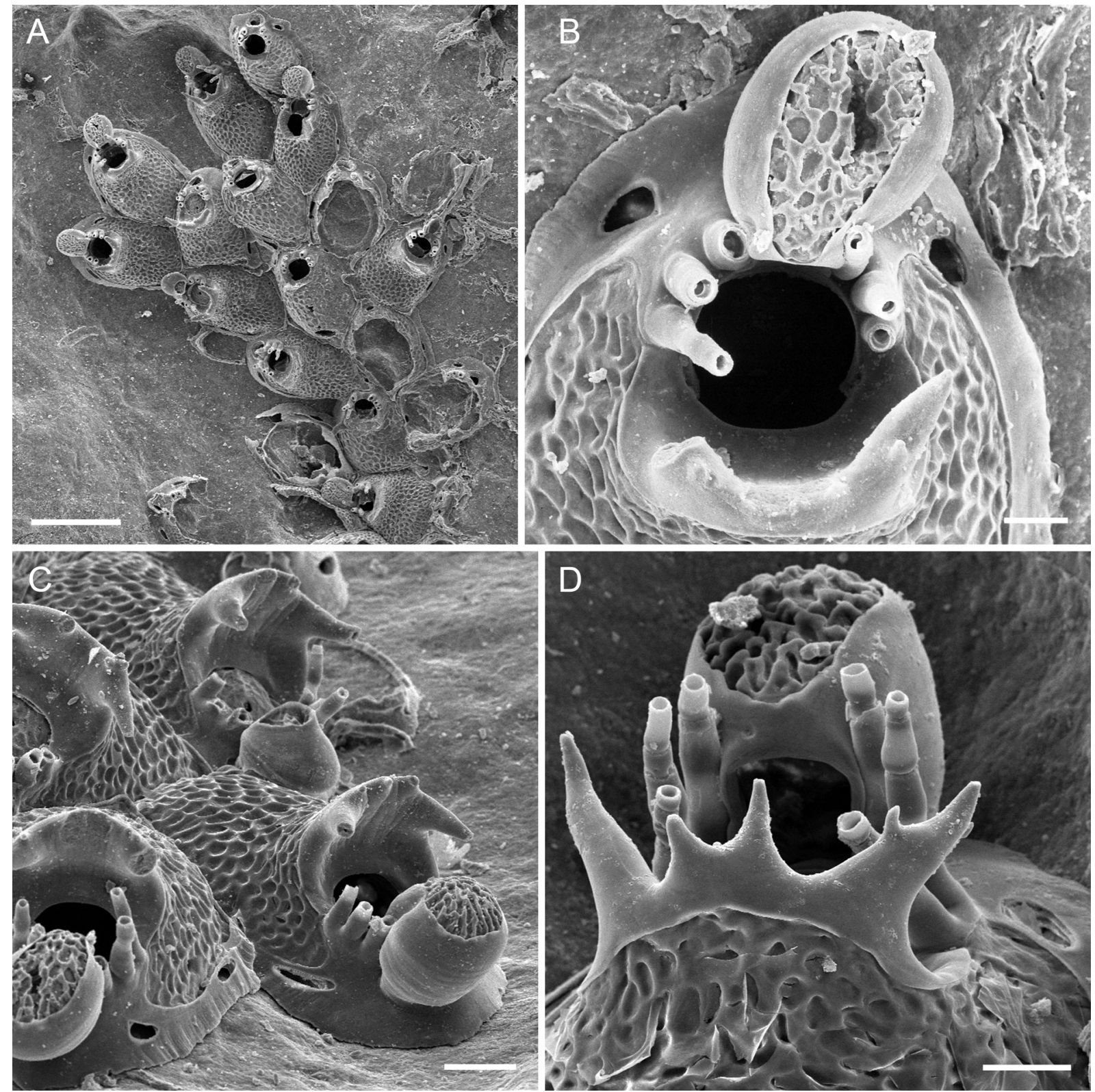

Fig. 7. Atlantisina lionensis gen. et sp. nov., Lion Smt, paratype (MNHN-IB-2014-67). A. Colony overview. B. Orifice and slightly damaged ooecium. C. Ovicellate zooids at the colony growth margin. D. Close-up of the suboral crest. Scale bars: $A=500 \mu \mathrm{m} ; \mathrm{B}, \mathrm{D}=50 \mu \mathrm{m} ; \mathrm{C}=100 \mu \mathrm{m}$. 
distolateral margins with six thick spines arranged in two groups of three with a distinct distal gap; all six spines present in ovicellate zooids with distal pair abutting proximolateral ooecial wall and flanking ooecial aperture on both sides.

Ovicell hyperstomial, ooecium barely resting on frontal shield of distal zooid, globular, slightly longer than wide, with a very short tubular peristome opening at distal orifice margin (Figs 1A, 7B-D); ectooecium relatively broad, covering about two-thirds of ooecium; exposed endooecium relatively small, surface topography similar to that of frontal shield but with steeper ridges delimiting smaller elongated concavities; ooecial aperture slightly taller than wide, acleithral.

Only ancestrula observed has 11 long and thin spines with four oral ones that are oriented vertically and seven mural ones that bend over opesia.

\section{Remarks}

The high morphological plasticity of the suboral crest in Atlantisina lionensis gen. et sp. nov., with a great variability in the number and shape of the mucrones occurring even within the same colony (Fig. 8), is a typical feature of this species. However, with two prominent lateral mucrones pointing in distal directions and shorter intermediate ones, the shape of the suboral crest of A. lionensis gen. et sp. nov. is in general similar to that of $A$. tricornis gen. et sp. nov., and also to the even larger ones in A. gorringensis gen. et sp. nov. and $A$. acantha gen. et sp. nov. (see below).

\section{Ecology}

The bi- to triserial colonies of Atlantisina lionensis gen. et sp. nov. were recovered from depths between 320 and $630 \mathrm{~m}$, encrusting small rocks.

\section{Distribution}

The species occurs on the Lion and Seine seamounts.
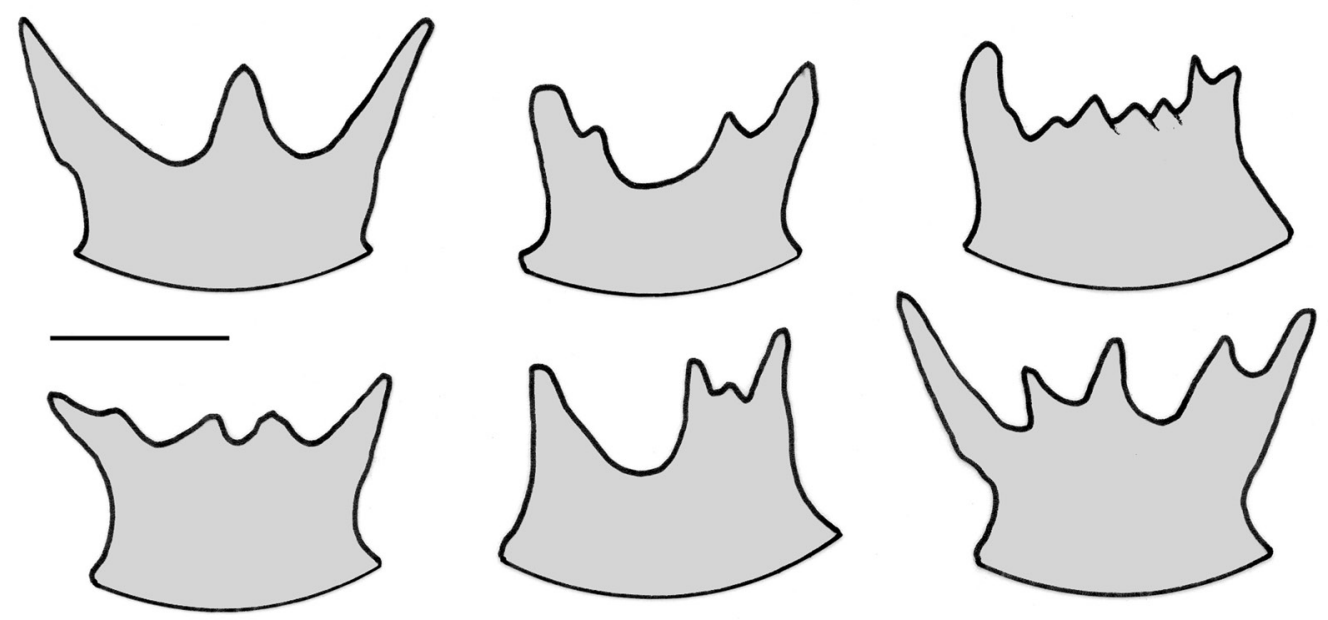

Fig. 8. Atlantisina lionensis gen. et sp. nov. Intraspecific variability in the morphology of the suboral crest. Scale bar: $200 \mu \mathrm{m}$. 
Atlantisina gorringensis gen. et sp. nov. urn:lsid:zoobank.org:act:7E59E329-59B0-496B-ACE5-63C4350AD88D

Fig. 9A-E, Table 9

\section{Diagnosis}

Zooids comparatively small, frontal shield with a reticulate pattern of raised ridges encircling round to polygonal depressions, the longitudinal ridges often more pronounced than the transversal ones, shield distolaterally raising to form a large and slightly flaring collar that is equipped with up to eight short pointed mucrones, the lateral pair usually pointing distally; lateral walls reduced, septular pores therefore relatively small and elongated, the distal pore large and suborbicular. Orifice comparatively small, orbicular, with a straight proximal margin, as long as wide, short condyles thickened and rounded, orifice margin with six spines. Ectooecium relatively extensive, covering approximately two-thirds of
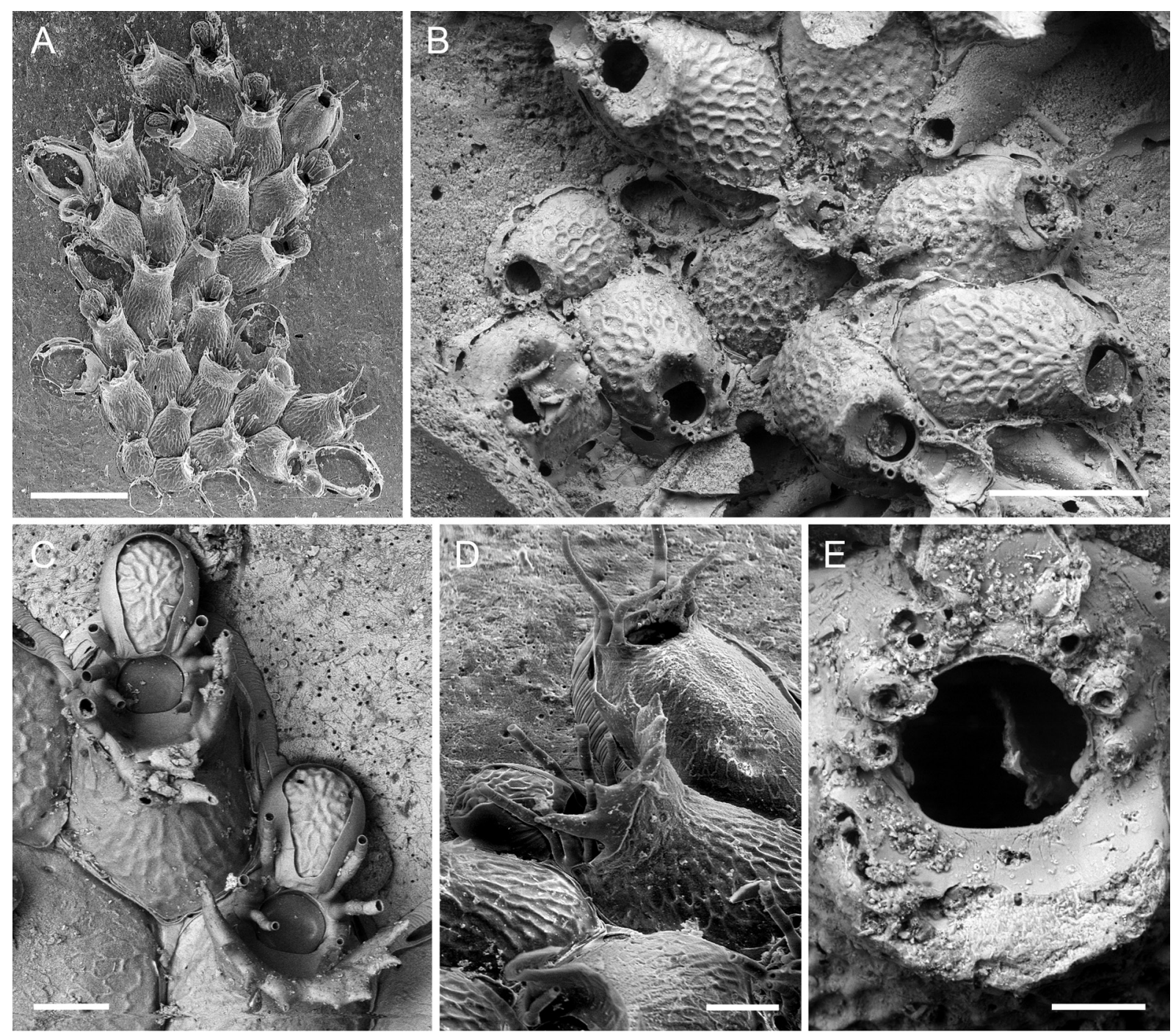

Fig. 9. Atlantisina gorringensis gen. et sp. nov., Gorringe Bank. A. Overview of holotype (MNHNIB-2014-70). B. Periancestrular region, the constricted oral region of the partly overgrown ancestrula is to the left (paratype OLL 2016/147). C. Two ovicellate zooids, the lower one with a well-preserved suboral crest (MNHN-IB-2014-70). D. The same zooid in lateral view (MNHN-IB-2014-70). E. Closeup of orifice (OLL 2016/147). Scale bars: A $=500 \mu \mathrm{m} ; \mathrm{B}=300 \mu \mathrm{m} ; \mathrm{C}-\mathrm{D}=100 \mu \mathrm{m} ; \mathrm{E}=50 \mu \mathrm{m}$. 
BERNING B. et al., New bathyal Bryozoa from the NE Atlantic

Table 9. Measurements of Atlantisina gorringensis gen. et sp. nov.

\begin{tabular}{ccccccc}
\hline & ZL & ZW & OL & OW & OvL & OvW \\
\hline Mean & 427 & 260 & 80 & 89 & 169 & 147 \\
SD & \pm 35 & \pm 16 & \pm 4 & \pm 5 & \pm 12 & \pm 19 \\
$\#$ & 21 & 21 & 7 & 7 & 7 & 7 \\
\hline
\end{tabular}

ooecium; endooecial surface as frontal shield, exposed area narrowing proximally. Ancestrula tatiform, opesia slightly constricted distally.

\section{Etymology}

Named after its type locality, Gorringe Bank.

\section{Material examined}

Holotype

GORRINGE BANK: 1 colony on shell, Stn 17 (MNHN-IB-2014-70).

Paratype

GORRINGE BANK: 1 colony on shell, Stn 17 (OLL 2016/147).

\section{Other material examined}

GORRINGE BANK: 2 small colonies on pebble, Stn 18 (unregistered MNHN material).

AMPÈRE SMT: 2 colonies on rocks, Stn 1 (unregistered MNHN material).

\section{Description}

Colony encrusting, unilaminar, forming small patches and bi- to triserial ribbons (Fig. 9A). Zooecia distinctly smaller than in other species of Atlantisina gen. nov., oval, separated by deep grooves and a thin ridge (Fig. 9B-C). Frontal shield convex, surface with a reticulate pattern of raised ridges encircling round to polygonal depressions, occasionally longitudinal ridges more pronounced than lateral ones (Fig. 9B-D), imperforate except for a few small marginal pores hardly visible in frontal view or in older zooecia; proximolateral suboral area framed by a tall, steeply rising and slightly flared collar, marginally abutting proximal pair of spines, crest of collar with some six short, pointed mucrones, outer pair longer and pointing distally (Fig. 9B-D); smooth gymnocystal calcification forming distal and terminal part of collar is clearly demarcated from proximal reticulate pattern of cryptocystal-type frontal shield by a distinct suture; lateral walls moderately well developed, (disto)lateral septular pores elongated, area of cryptocystal-type calcification surrounding pores reduced to a thin lining; distal ooecial pore large, suborbicular.

Orifice distinctly smaller in than other species of Atlantisina gen. nov., suborbicular, as long as broad, widest at about mid-distance, proximal border fairly straight, proximal fourth delimited by a pair of very short, thickened and rounded condyles (Fig. 9E); distolateral margins equipped with six whip-like spines with thick bases, arranged in two groups of three with a distinct distal gap; all six spines present in ovicellate zooids with distal pair closely appressed to proximolateral ooecium wall.

Ovicell hyperstomial, ooecium barely resting on distal zooid's frontal shield, a laterally compressed sphere, longer than broad, with a short tubular peristome wedged in between distalmost pair of spines and opening at distal orifice margin, ooecial aperture orbicular, acleithral (Fig. 9C); smooth ectooecium covering about two-thirds of ooecium; exposed endooecium reduced to centre, narrowing proximally, surface topography similar to frontal shield but with narrower elongated depressions. 
Ancestrula tatiform, constricted in distal part, first generation autozooid budded distally or distolaterally (Fig. 9B).

\section{Remarks}

This species differs from its closest allies, Atlatisina lionensis gen. et sp. nov. and A. acantha gen. et sp. nov. (see below), in that the longitudinal ridges on the frontal shield are sometimes more pronounced than the transversal ones, occasionally giving the surface a striped appearance instead of a honeycomb structure. Moreover, the condyles are distinctly thickened in A. gorringensis gen. et sp. nov., and the suboral crest is equipped with six to eight relatively short mucrones of almost equal lengths (only the distolateral ones may be slightly longer). The crest is also distinctly curved around the proximolateral orifice in this species, instead of being rather straight as in A. lionensis gen. et sp. nov., but does not reach quite as far distally, and is not as thickly calcified, as in A. acantha gen. et sp. nov. Finally, A. gorringensis gen. et sp. nov. has distinctly smaller zooids and orifices than all other species in this genus (Table 9).

\section{Ecology}

The bi- to triserial colonies encrust small rocks and shells at depths of 180 to $330 \mathrm{~m}$.

\section{Distribution}

Atlantisina gorringensis gen. et sp. nov. occurs on Gorringe Bank and Ampère Smt.

Atlantisina acantha gen. et sp. nov. urn:1sid:zoobank.org:act:8F0594E7-42C5-429C-8DBC-0AA244256C4F

Fig. 10A-E, Table 10

\section{Diagnosis}

Frontal shield with a reticulate pattern of raised ridges encircling round to polygonal depressions, distolaterally raising to form a huge flaring collar that is equipped with several pointed mucrones and that surrounds at least the proximal half of the orifice; lateral walls reduced proximally and laterally, septular pores therefore small and very elongated, the slightly raised distal pore large and suborbicular. Orifice orbicular, condyles very short and not thickened distally, orifice margin with six spines. Ectooecium covering slightly more than lower half of ooecium, endooecial surface as frontal shield but with narrower and more irregularly shaped elongate depressions. Ancestrula with 11 or 13 spines, opesia rather oval, not pyriform.

\section{Etymology}

From the Greek Aאóv $\theta \alpha$ (Eng.: thorny) for its thorn-bearing peristome.

\section{Material examined}

Holotype

CANARY ISLANDS: 1 ovicellate colony with an ancestrula on a pebble, together with an immature colony, Stn 12 (MNHN-IB-2014-71).

\section{Paratype}

CANARY ISLANDS: 1 damaged colony on a rock fragment, Stn 12 (MNHN-IB-2014-72).

\section{Description}

Colony encrusting, unilaminar, forming small patches and bi- to triserial ribbons (Fig. 10A). Zooecia oval, separated by deep grooves and a thin ridge. Frontal shield convex, surface with a reticulate pattern 
BERNING B. et al., New bathyal Bryozoa from the NE Atlantic

Table 10. Measurements of Atlantisina acantha gen. et sp. nov.

\begin{tabular}{ccccccc}
\hline & ZL & ZW & OL & OW & OvL & OvW \\
\hline Mean & 598 & 415 & 119 & 123 & 190 & 256 \\
SD & \pm 29 & \pm 34 & \pm 4 & \pm 11 & - & - \\
$\#$ & 5 & 5 & 6 & 6 & 1 & 1 \\
\hline
\end{tabular}

of raised ridges encircling round to polygonal depressions (Fig. 10C), imperforate except for some four small marginal pores hardly visible in frontal view or in older zooecia; suboral area occupied by a tall, thickly calcified and flaring collar encircling almost two-thirds of orifice and sloping abruptly towards orifice and laterally towards first or second pair of spines, crest of collar serrated by up to seven large, pointed mucrones of different shape and height, longest ones distalmost, pointing distally; smooth gymnocystal calcification comprising distal part of collar clearly demarcated from proximal reticulate pattern of cryptocystal-type frontal shield by a wavy line, with wave peaks at bases of mucrones
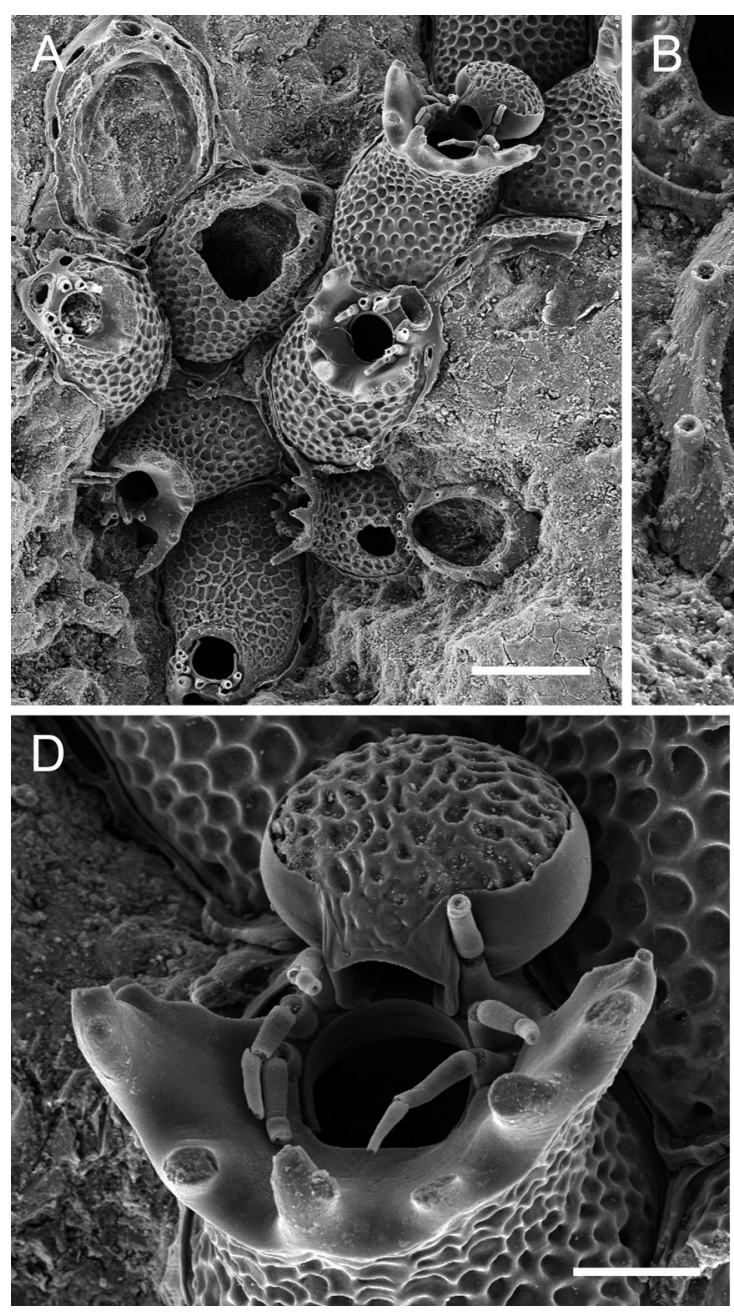
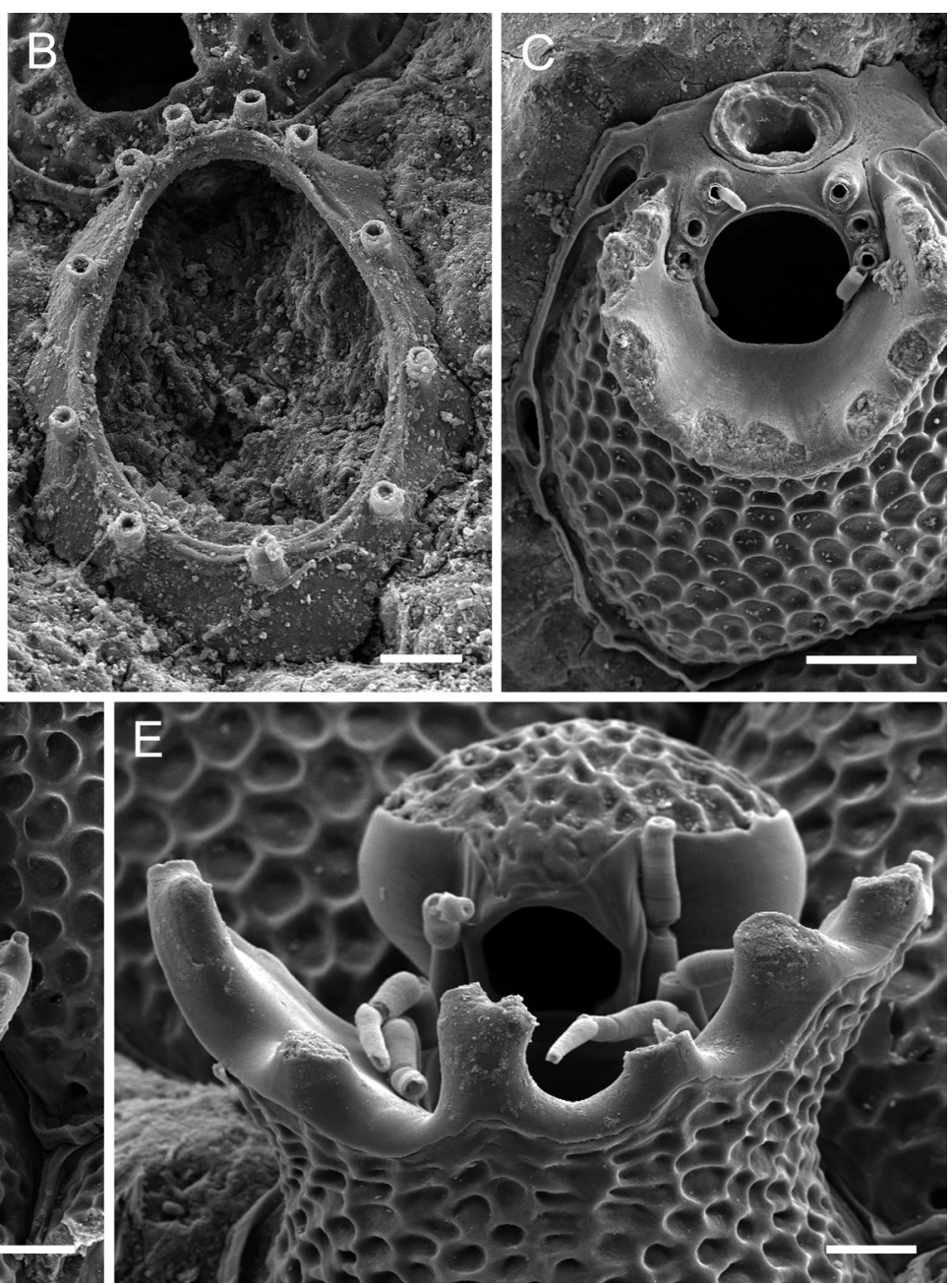

Fig. 10. Atlantisina acantha gen. et sp. nov., Canary Islands, holotype (MNHN-IB-2014-71). A. Overview of the young, yet mature, colony. B. Close-up of ancestrula. C. Autozooid with orifice; note the large distal ooecial pore and the narrow lateral gymnocystal walls with relatively small communication pores. D. Close-up of ooecium and the suboral crest. E. Lateral view of the suboral crest; note that the tips are all broken. Scale bars: A $=300 \mu \mathrm{m} ; \mathrm{B}, \mathrm{E}=50 \mu \mathrm{m} ; \mathrm{C}, \mathrm{D}=100 \mu \mathrm{m}$. 
(Fig. 10A, D-E); lateral walls well developed only in distal part of zooecium, narrow laterally, (disto) lateral septular pores comparatively small, transversely oval to extremely narrow and elongate, area surrounding pores therefore reduced; distal ooecial pore large, suborbicular, surrounded by a broad nodular area (Fig. 10C).

Orifice orbicular, widest at about mid-distance, proximal border fairly straight, proximal fourth delimited by a pair of very short, blunt condyles that parallel orifice margin (Fig. 10C); distolateral margins equipped with six whip-like spines with thick bases, arranged in two groups of three with a distinct distal gap; all six spines present in ovicellate zooids with distal pair almost incorporated into proximolateral ooecium wall.

Ovicell hyperstomial, ooecium barely resting on distal zooid's frontal shield, a compressed sphere, the only observed one broader than long, with a short tubular peristome wedged in between distalmost pair of spines and opening at distal orifice margin, ooecial aperture orbicular, acleithral (Fig. 10D); ectooecium covering a little more than lower half; exposed endooecium extensive, hemispherical, surface topography similar to that of frontal shield but with smaller elongated depressions.

Ancestrula longer than wide (ca $370 \mu \mathrm{m}$ long, $290 \mu \mathrm{m}$ wide), smooth gymnocyst very narrow and similarly steeply sloping all around, cryptocyst practically absent (Fig. 10B); opesia extensive (ca $280 \mu \mathrm{m}$ long, $200 \mu \mathrm{m}$ wide), oval, somewhat narrowing distally, surrounded by 11 or 13 spines, in which distal four are situated slightly closer together; first generation autozooid budded distally or distolaterally (Fig. 10A).

\section{Remarks}

Atlantisina acantha gen. et sp. nov. has the most impressive suboral structure in this genus. A vertical outgrowth of the frontal shield forms a huge flaring collar around the proximal half, or even two-thirds, of the orifice, occasionally levelling only at the distal pair of spines. Moreover, this massively calcified collar is equipped with several pointed and occasionally branching mucrones, the largest lateral ones pointing distally and reaching beyond the zooid border.

Atlantisina acantha gen. et sp. nov. is morphologically close to A. lionensis gen. et sp. nov. and A. gorringensis gen. et sp. nov., particularly in having both a broad and tall suboral structure with pointed mucrones, and also the same reticulate pattern on the frontal shield and the exposed endooecium. However, the suboral structure forms a flared collar in $A$. acantha gen. et sp. nov., while it is planar and laterally more reduced in $A$. lionensis gen. et sp. nov. These two species also differ in the size of certain characters, particularly in the ooecium width, which is clearly larger in $A$. acantha gen. et sp. nov. with a ratio of ooecium length/width $<1$, while it is $>1$ in A. lionensis gen. et sp. nov. Unfortunately, the number of measurements that could be taken of $A$. acantha gen. et sp. nov. were insufficient for statistical comparisons. Atlantisina gorringensis gen. et sp. nov. furthermore differs from A. acantha gen. et sp. nov. in having distinctly smaller zooids and orifices, and the suboral crest always terminates at the proximal pair of oral spines.

Another peculiarity in A. acantha gen. et sp. nov. are the gymnocystal lateral margins, which are, in contrast to all other species of Atlantisina gen. nov., often reduced to a thin band surrounding very narrow and elongated septular pores (Fig. 10C). The distal suborbicular pore through which the ooecium is budded is, on the other hand, comparatively large. Atlantisina acantha gen. et sp. nov. also differs from most other congeners in its ancestrula (Fig. 10B), which has 11 to 13 mural spines instead of the usual nine (only A. gorringensis gen. et sp. nov. has 12 spines). 


\section{Ecology}

In the holotype, the only mature colony available for study, an ovicell is formed very early in astogeny (presumably in the seventh zooid, see Fig. 10A), showing characters of a spot colony (cf. Bishop 1989). As the other species of Atlantisina gen. nov., A. acantha gen. et sp. nov. forms small patches and bi- to triserial colonies, which encrust small rocks and occur at around $660 \mathrm{~m}$ depth.

\section{Distribution}

Atlantisina acantha gen. et sp. nov. occurs sympatrically with $A$. inarmata gen. et sp. nov. off NW Gran Canaria (Canary Islands).

\section{Genus Bathycyclopora gen. nov. \\ urn:1sid:zoobank.org:act:E45D211D-BAC1-41CD-8AC5-458335BE6A69}

\section{Type species}

Phylactella vibraculata Calvet, 1931.

\section{Diagnosis}

Colony encrusting, unilaminar, multiserial, budding intrazooidal. Zooidal frontal shield umbonuloid, imperforate except for a row of marginal pores; entire zooidal surface of interior calcification except for the proximal and distolateral gymnocystal orifice margins; lateral walls generally extensive, with a single large pore chamber per neighbouring zooid, septular pore round, encompassed by a large cryptocystal area, a fine band of gymnocystal calcification delimiting each pore chamber from the neighbouring one. Orifice D-shaped or rather square, with condyles, an immersed distal shelf may be present; oral spines present. Potentially maternal zooids slightly dimorphic, with a distal gap between spines, ooecium produced by the zooid distal to the maternal one, hyperstomial, recumbent on the distal zooid's frontal shield; ectooecium reduced to a thin frame surrounding the entire ooecial base; endooecium entirely calcified, imperforate; not closed by operculum (acleithral). Adventitious and interzooidal avicularia present. Ancestrula tatiform, opesia extensive, with a slight distal constriction; gymnocyst relatively narrow all around, cryptocyst absent.

\section{Etymology}

The name alludes to its bathyal habitat, and is combined with the latter part of the name of the genus Hemicyclopora, which it superficially resembles. Gender feminine.

\section{Remarks}

Bathycyclopora gen. nov. superficially resembles the romancheinid genera Hemicyclopora and Escharella, but differs from both in having (i) well-developed lateral walls with just one communication pore per neighbouring zooid; (ii) adventitious and interzooidal avicularia; (iii) a partially calcified ectooecium; and (iv) a simple tatiform ancestrula in which a cryptocyst is absent. The new genus differs from Atlantisina gen. nov. in the presence of avicularia, in the distinctly less developed ectooecium, and lateral walls that are predominantly composed of cryptocyst and which contain distinctly smaller communication pores. Moreover, whereas non-reproducing zooids and maternal zooids are monomorphic in Atlantisina gen. nov. (all zooids have the potential to eventually produce ovicells and have a distal gap between the oral spines to accommodate the ooecial aperture), the oral spines in Bathycyclopora gen. nov. are evenly distributed around the orifice in non-reproducing zooids, whereas a central gap exists only in potentially maternal zooids (not all of these zooids necessarily produce an ovicell). Moreover, the ooecium in Bathycyclopora gen. nov. is not a kenozooid produced by the maternal zooid as in Atlantisina gen. nov. but is formed by the zooid distal to the maternal one. The distal septular pore in Bathycyclopora gen. nov. is not as raised as in Atlantisina gen. nov. and is involved in budding a distal 
zooid or interzooidal avicularium, whereas in Atlantisina gen. nov. only an ooecium may be produced from this pore and it remains visible above the level of the frontal shield of the distal zooid throughout ontogeny in case no ovicell is formed. The structure of the ooecium is, however, very similar in both genera, although the ectooecium is less well developed in Bathycyclopora gen. nov.

The only two species in the genus are geographically restricted to central Atlantic islands (Azores) and seamounts (Atlantis). They have been recorded from the upper bathyal slope (400-600 m).

Bathycyclopora vibraculata (Calvet, 1931) gen. et comb. nov.

Fig. 11A-F, Table 11

?Phylactella vibraculata Calvet, 1931: 113, pl. 2, figs 17-18.

\section{Material examined}

Lectotype (here designated)

AZORES: 2 ovicellate colonies on a coral fragment, the larger one with an ancestrula is the lectotype (MOM INV-22480a), the smaller one a paralectotype (MOM INV-22480b), dry, Stn 2.

\section{Paralectotypes}

AZORES: 1 colony on coral fragment, dry, Stn 2 (MOM INV-22679); 1 colony on coral fragment, dry, Stn 2 (MOM INV-22680); 1 colony fragment, dry, on slide, severely affected by Bynesian decay, Stn 2 (MOM INV-22479).

\section{Description}

Colony encrusting, unilaminar, multiserial, forming small patches (Fig. 11A). Zooids relatively large, hexagonal or polygonal, separated by grooves (Fig. 11B-C); lateral walls well developed, becoming more extensive distally, gently sloping, with a single basal pore chamber connecting each neighbouring zooid (Fig. 11C), round septular pore surrounded by a large area of cryptocyst with a surface similar to that of frontal shield, framed by a narrow and slightly raised ridge of gymnocystal calcification, separated from neighbouring pore chamber by a suture, pore in distal pore chamber slightly raised with respect to lateral ones. Frontal shield convex, imperforate except for a single row of numerous conspicuous marginal pores, gently rising distally towards a suboral crest with a blunt or occasionally triangular central umbo that is laterally sloping towards proximal pair of spines (Fig. 11D); surface rugose and with irregular wrinkles, superimposed by fine granules.

Orifice about as wide as long, distal half rounded and with a conspicuous immersed shelf along entire distal margin, lateral margins parallel, proximal edge slightly concave; condyles conspicuous, rectangular or roughly triangular, distinctly set off from orifice margins (Fig. 11F); distolateral orifice margin with seven or rarely six evenly spaced spines, six spines with a distinct distal gap in potentially maternal zooids.

Ovicell hyperstomial, ooecium resting on or slightly immersed in distal zooid's frontal shield (Fig. 11D), globular, in general wider than long, with a very short tubular peristome wedged in between distalmost pair of spines and terminating at distal orifice margin; smooth ectooecium a narrow band around base of ooecium, broadening proximally to frame ooecial aperture (Fig. 11E); exposed endooecium imperforate, surface topography similar to that of frontal shield; ooecial aperture suborbicular, not closed by operculum.

Adventitious avicularia paired, small, oval, lateral to orifice near distolateral zooidal corners (Fig. 11DE); rostrum short, semicircular to semielliptical, slightly raised distally, directing laterally or distolaterally, 
BERNING B. et al., New bathyal Bryozoa from the NE Atlantic

Table 11. Measurements of Bathycyclopora vibraculata (Calvet, 1931) gen. et comb. nov.

\begin{tabular}{ccccccccccc}
\hline & ZL & ZW & OL & OW & OvL & OvW & aAL & aAW & iAL & iAW \\
\hline Mean & 823 & 637 & 165 & 163 & 255 & 291 & 57 & 46 & 264 & 140 \\
SD & \pm 87 & \pm 93 & \pm 14 & \pm 12 & \pm 31 & \pm 14 & \pm 8 & \pm 6 & \pm 36 & \pm 8 \\
$\#$ & 30 & 30 & 20 & 20 & 11 & 11 & 20 & 20 & 9 & 9 \\
\hline
\end{tabular}

palate an immersed distolateral shelf framing a suborbicular opesia; crossbar incomplete, composed of two short inwardly curved triangular condyles, proximal uncalcified area reduced, semicircular. Interzooidal avicularia frequent in late astogenetic parts of colony, emplaced on a polygonal cystid with variably developed cryptocyst-type granular frontal shield and a row of marginal pores as in autozooids (Fig. 11C-D); rostrum slightly to distinctly spatulate, slightly raised distally, of variable size and pointing in various directions, most of palate occupied by a broad flat shelf with a V-shaped proximal edge caused by indentation of distal uncalcified area; crossbar broad laterally and much thinner
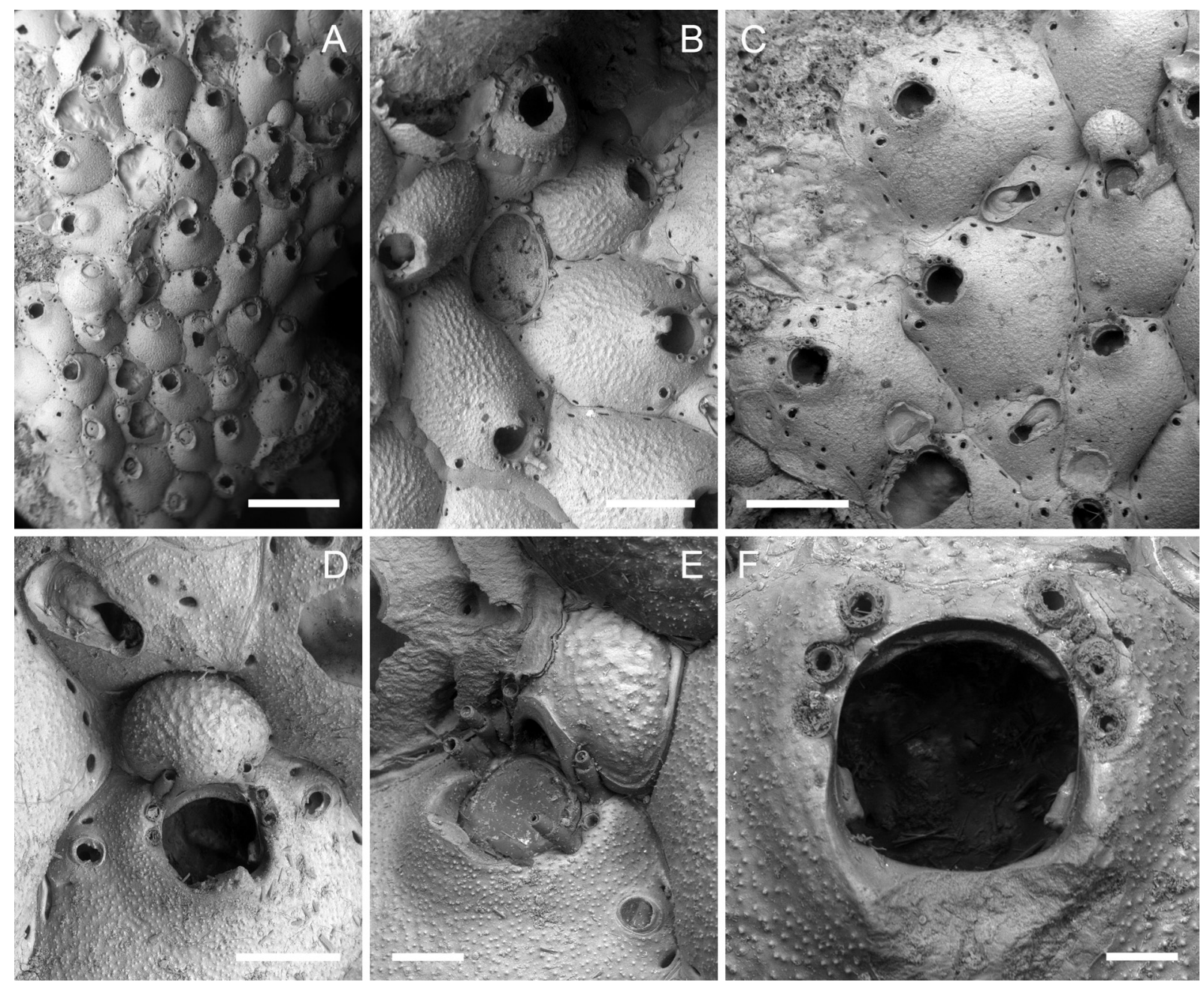

Fig. 11. Bathycyclopora vibraculata (Calvet, 1931) gen. et comb. nov., Azores. A. Overview of lectotype (MOM INV-22480a). B. Periancestrular region (MOM INV-22480a). C. Zooids at the colony growth margin and interzooidal avicularia (paralectotype, MOM INV-22480b). D. An ovicellate zooid and an interzooidal avcularium (paralectotype, MOM INV-22480b). E. Lateral view of an ooecium showing the thin marginal band of ectooecium (MOM INV-22480a). F. Close-up of orifice (MOM INV-22480a). Scale bars: $A=1 \mathrm{~mm} ; \mathrm{B}=300 \mu \mathrm{m} ; \mathrm{C}=500 \mu \mathrm{m} ; \mathrm{D}=200 \mu \mathrm{m} ; \mathrm{E}=100 \mu \mathrm{m} ; \mathrm{F}=50 \mu \mathrm{m}$. 
towards centre when complete, or reduced to a pair of short triangular condyles; proximal uncalcified area reduced, semicircular.

Ancestrula tatiform, oval (ca $500 \mu \mathrm{m}$ long, $350 \mu \mathrm{m}$ wide), smooth gymnocyst presumably narrow all around, cryptocyst absent; opesia large (ca $380 \mu \mathrm{m}$ long, $260 \mu \mathrm{m}$ wide), oval, slightly constricted in distal fifth; 11 spines, with five proximal ones widely spaced and six distal ones situated closer together (Fig. 11B).

\section{Remarks}

As Calvet (1931) did not explicitly mention a holotype, we here designate as lectotype the specimen that was presumably depicted on pl. 2, figs 17-18. The species epithet stems from a misinterpretation of the small adventitious avicularia, which Calvet (1931: 114) thought were vibracula. The mandible is, however, confined to the rostrum, moves in one plane only, and is therefore a normal avicularium (Fig. 11E). Bathycyclopora vibraculata gen. et comb. nov. has never been reported again after its discovery.

\section{Ecology}

All available colonies encrust dead coral skeletons at ca $600 \mathrm{~m}$ depth, forming small patches.

\section{Distribution}

Bathycyclopora vibraculata gen. et comb. nov. was found at a single station off NW Terceira Island (Azores).

$$
\begin{aligned}
& \text { Bathycyclopora suroiti gen. et sp. nov. } \\
& \text { urn:1sid:zoobank.org:act:84D62316-64CF-4429-9610-D8A26DDA83D9 }
\end{aligned}
$$

Fig. 12A-G, Table 12

\section{Diagnosis}

Bathycyclopora suroiti gen. et sp. nov. differs from the type species B. vibraculata gen. et comb. nov. in having a frontal shield with slightly more pronounced ridges, seven or eight oral spines in non-maternal zooids, distinctly smaller and blunt condyles, a narrower shelf at the distal orifice margin, slightly longer and less spatulate interzooidal avicularia, a distinctly broader ectooecium around the ooecial margin, ooecia that are only slightly wider than long, and an ancestrula with 13 instead of 11 spines.

\section{Etymology}

The species is named after the French research vessel 'Le Suroît', and the cruise 'Suroît Seamount 2', which aimed at sampling the central North Atlantic seamounts.

\section{Material examined}

\section{Holotype}

ATLANTIS SMT: 1 ovicellate colony on stylasterid skeleton, Stn 7 (MNHN-IB-2014-73).

\section{Paratypes}

ATLANTIS SMT: 1 ovicellate colony on rock, Stn 6 (MNHN-IB-2014-74); 2 colonies on stylasterid skeleton, Stn 7 (MNHN-IB-2014-75); 1 coated colony on stylasterid skeleton, Stn 7 (MNHNIB-2014-76); 1 coated colony on stylasterid skeleton, Stn 7 (MNHN-IB-2014-77); 1 colony on stylasterid skeleton, Stn 7 (OLL 2016/126); 1 colony on stylasterid skeleton, Stn 7 (OLL 2016/148); 1 colony on foraminiferal sandstone, mounted on SEM-stub, sputter-coated, Stn 5 (OLL 2016/149). 


\section{Other material examined}

ATLANTIS SMT: 1 colony on biogenic rock, Stn 3 (unregistered MNHN material); 7 colonies on stylasterid skeleton plus 3 colonies on coral skeleton, Stn 7 (unregistered MNHN material); 1 colony on coral, Stn 7 (OLL 2016/150); 1 colony on bioclast, Stn 7 (OLL 2016/151); 14 colonies on stylasterid skeleton, Stn 7 (OLL 2016/152).

\section{Description}

Colony encrusting, unilaminar, multiserial, forming small patches (Fig. 12A). Zooids polygonal, separated by grooves; lateral walls well developed, becoming more extensive distally, gently sloping, with a single basal pore chamber connecting neighbouring zooids, communication via a round septular pore situated in centre of a large cryptocystal area with a surface similar to frontal shield (Fig. 12E), framed by a narrow and slightly raised ridge, only the basal part of which is gymnocystal. Frontal shield matted vitreous, convex, gently raising distally towards a short blunt central umbo on a suboral crest
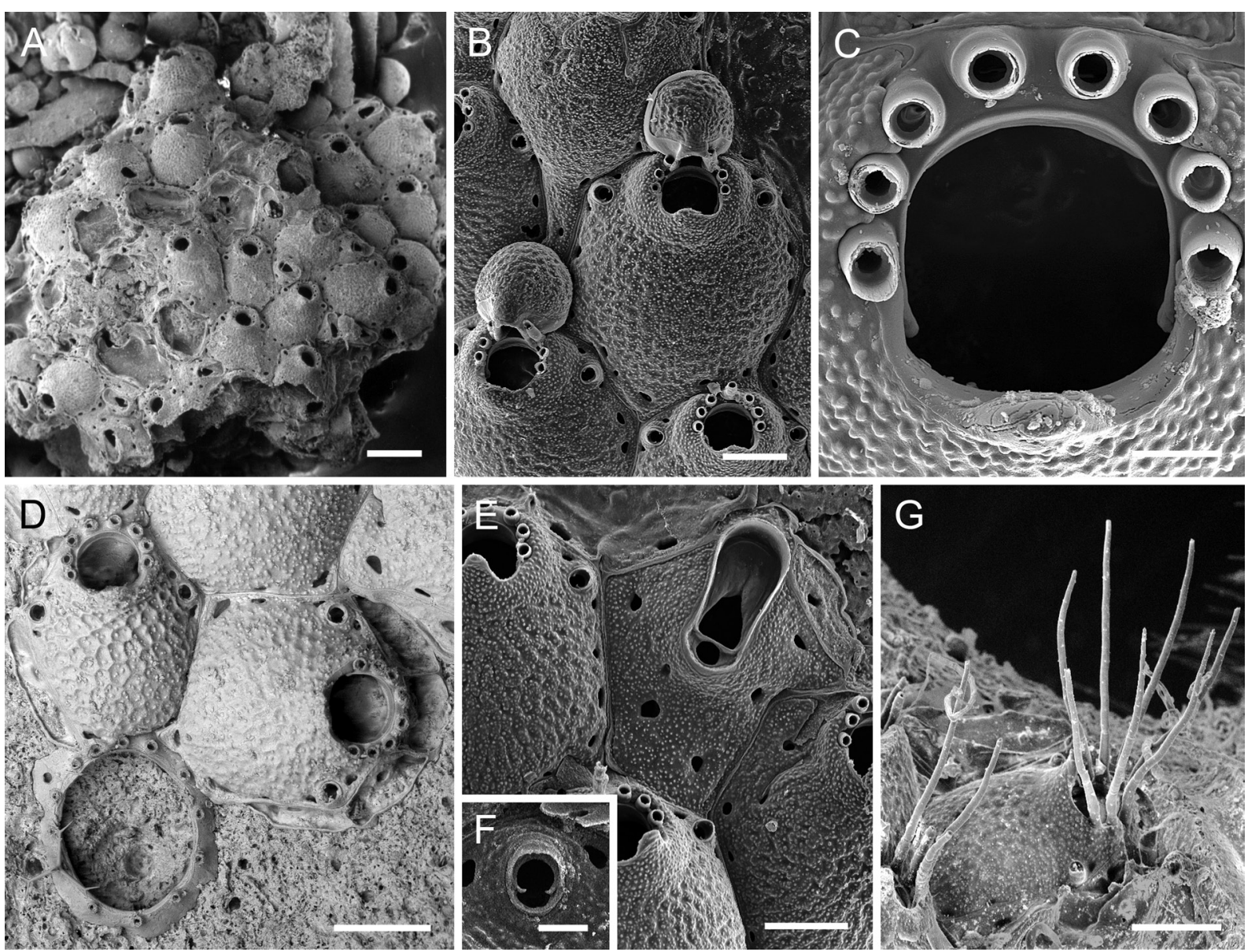

Fig. 12. Baythycyclopora suroiti gen. et sp. nov., Atlantis Smt. A. Overview of a partly damaged colony (paratype, OLL 2016/149). B. Ovicellate zooids (paratype, MNHN-IB-2014-77). C. Close-up of an orifice (paratype, MNHN-IB-2014-77). D. Ancestrula and the first two autozooids (paratype, OLL 2016/126). E. Interzooidal avicularium; note the single communication pore per neighbouring zooid as well as the extensive cryptocystal calcification surrounding it and the thin peripheral band of gymnocyst (paratype, MNHN-IB-2014-77). F. Close-up of adventitious avicularium (paratype, MNHNIB-2014-77). G. Lateral view of oral spines (holotype, MNHN-IB-2014-73). Scale bars: A $=500 \mu \mathrm{m}$; $\mathrm{B}, \mathrm{D}-\mathrm{E}, \mathrm{G}=200 \mu \mathrm{m} ; \mathrm{C}, \mathrm{F}=50 \mu \mathrm{m}$. 
Table 12. Measurements of Bathycyclopora suroiti gen. et sp. nov.

\begin{tabular}{ccccccccccc}
\hline & ZL & ZW & OL & OW & OvL & OvW & aAL & aAW & iAL & iAW \\
\hline Mean & 766 & 577 & 156 & 162 & 277 & 285 & 57 & 46 & 295 & 135 \\
SD & \pm 82 & \pm 91 & \pm 11 & \pm 11 & \pm 18 & \pm 18 & \pm 6 & \pm 4 & \pm 49 & \pm 18 \\
$\#$ & 11 & 11 & 6 & 6 & 14 & 14 & 16 & 16 & 7 & 7 \\
\hline
\end{tabular}

that is laterally gently sloping towards proximal pair of spines and distally vertically dropping towards orifice (Fig. 12B, E); frontal shield imperforate except for a single row of 14-18 relatively conspicuous marginal pores, surface a meshwork of faint ridges superposed by a finely granular pattern (Fig. 12B).

Orifice about as wide as long, rounded D-shaped with a straight or slightly concave proximal edge and a narrow shelf along distal orifice margin (Fig. 12C); condyles small with blunt tip; distolateral orifice margin in non-maternal zooids with seven or eight spines (Fig. 12C, G), potentially maternal zooids with six spines with a distinct gap between distal pair to accommodate ooecial aperture, spines particularly long $(580-725 \mu \mathrm{m})$.

Ovicell hyperstomial, ooecium resting on or slightly immersed in distal zooid's frontal shield (Fig. 12B), globular, slightly wider than long, with a very short tubular peristome wedged in between distalmost pair of spines and terminating at distal orifice margin; smooth ectooecium a relatively broad band around lower part of ooecium, narrowing proximally towards peristome; exposed endooecium extensive, imperforate, surface topography similar to that of frontal shield; ooecial aperture suborbicular, not closed by operculum.

Adventitious avicularia paired, small, oval, lateral to orifice near distolateral zooidal corners (Fig. 12B, D); rostrum short, semicircular to semielliptical, slightly raised distally, directing laterally or distolaterally, palate a narrow immersed distolateral shelf framing a suborbicular opesia; crossbar incomplete, composed of two short curved condyles, proximal uncalcified area semicircular (Fig. 12F). Interzooidal avicularia frequent in late astogenetic parts of colony, placed on large polygonal cystid with variably developed cryptocyst-type granular frontal shield and a row of five to seven, relatively large marginal pores as in autozooids (Fig. 12E); rostrum spatulate, slightly raised distally, of variable size and pointing in various directions, with tip reaching one of the cystid corners, most of palate occupied by a broad distal shelf narrowing proximally, distal uncalcified area large, elongate and roughly triangular; mandible hinged on short triangular condyles or on complete crossbar, proximal uncalcified area subcircular.

Ancestrula tatiform, oval (ca $460 \mu \mathrm{m}$ long, $360 \mu \mathrm{m}$ wide), smooth gymnocyst narrow all around, cryptocyst absent (Fig. 12D); opesia large (ca $330 \mu \mathrm{m}$ long, $270 \mu \mathrm{m}$ wide), oval, very slightly constricted in distal fifth; 13 spines, with seven proximal ones more widely spaced and six distal ones situated slightly closer together.

\section{Remarks}

The most obvious differences between Bathycyclopora suroiti gen. et sp. nov. and B. vibraculata gen. et comb. nov. are the distinctly smaller condyles, and the presence of eight spines in most zooids in the former species. Moreover, the structure of the frontal shield surface is more distinct than in B. vibraculata gen. et comb. nov., and is, especially in early ontogenetic zooids, reminiscent of the honeycomb structure of ridges in some species of Atlantisina gen. nov.

\section{Ecology}

Bathycyclopora suroiti gen. et sp. nov. occurs at depths of 275-460 m, encrusting stylasterid skeletons and other old biogenic substrata. 
BERNING B. et al., New bathyal Bryozoa from the NE Atlantic

\section{Distribution}

The species was found on the central Atlantic Atlantis and Hyères seamounts.

Genus Calvetopora gen. nov. urn:Isid:zoobank.org:act:95E74E9B-013C-4E02-8E66-E71E4CD93B34

\section{Type species}

Lepralia inflata Calvet, 1906.

\section{Diagnosis}

Colony encrusting, unilaminar, multiserial, budding intrazooidal. Zooidal frontal shield umbonuloid, perforated by several central pseudopores and a single series of pores at the zooecial margin; lateral walls moderately developed, mostly gymnocystal, two or more basal pore chambers per neighbouring zooid, septular pores relatively large, elongated oval, surrounded by cryptocystal-type calcification. Orifice D-shaped, condyles present but extremely small and invisible in perpendicular view, oral spines present. Maternal zooids slightly dimorphic, with a gap between distal pair of spines, ooecium either produced by the zooid distal to the maternal one, or formed by a kenozooid budded from the distal septular pore of the maternal zooid, hyperstomial, recumbent on the distal zooid's frontal shield; ectooecium partially calcified or entirely membranous; endooecium entirely calcified, imperforate; not closed by operculum (acleithral). Adventitious avicularia present. Ancestrula tatiform, opesia extensive, with a constriction in distal (oral) part; gymnocyst narrow all around, cryptocyst absent.

\section{Etymology}

Named in honour of Louis Calvet, who discovered and introduced the type species, in conjunction with -pora, a common ending of bryozoan genera, alluding to their perforate frontal shields.

\section{Remarks}

Calvetopora gen. nov. shares its paired, distolateral adventitious avicularia and also its large zooids with Bathycyclopora gen. nov., the main differences being the perforated frontal shield and the absence of interzooidal avicularia in Calvetopora gen. nov. On the other hand, with most of the outer surface formed by gymnocystal calcification, and septular pores that are surrounded by cryptocyst, the lateral walls in Calvetopora gen. nov. are rather similar to those of Atlantisina gen. nov., albeit not as well developed.

Interestingly, the mode of ooecium formation differs between species of Calvetopora gen. nov. Whereas the ooecium in Calvetopora inflata gen. et comb. nov. (Calvet, 1906) is produced by a kenozooid that is budded from the distal pore chamber of the maternal zooid, in Calvetopora otapostasis gen. et sp. nov. the ooecium is produced by the zooid distal to the maternal one (see below). Thus, Calvetopora gen. nov. combines characteristics of both Bathycyclopora gen. nov., in which the zooid distal to the maternal one produces the ooecium, and Atlantisina gen. nov., in which the maternal zooid forms a kenozooidal ooecium.

The ooecium itself may also vary between species in Calvetopora gen. nov.: while the ectooecium is entirely membranous in C. inflata gen. et comb. nov., it is partially calcified around the lower part of the ooecium in C. otapostasis gen. et sp. nov., just as in species of Atlantisina gen. nov. and Bathycyclopora gen. nov.

Interzooidal communication in species of Calvetopora gen. nov. takes place via one or two septular pores. They thus differ from species of Atlantisina gen. nov. and Bathycyclopora gen. nov., which have 
a single septular pore per neighbouring zooid, whereas certain Romancheinidae (e.g., Escharoides) also communicate via two pores with neighbouring zooids.

There is a large gap in geographic distribution between species of Calvetopora gen. nov., with C. inflata gen. et comb. nov. being reported from the Gulf of Cádiz and C. otapostasis gen. et sp. nov. from Atlantis Smt and the Great Meteor Bank. Moreover, the individual species have been recorded from a single or a few sites only. The species occur at depths of 400 to over $700 \mathrm{~m}$. Owing to their large size of about one millimetre, the zooids can easily be detected even with the naked eye.

Calvetopora inflata (Calvet, 1906) gen. et comb. nov.

Fig. 13A-F, Table 13

Lepralia inflata Calvet, 1906: 159.

Lepralia inflata-Calvet 1907: 411, pl. 27, fig. 10.

\section{Material examined}

Holotype (by monotypy)

GULF OF CÁDIZ: 1 colony on L. pertusa, Stn 24 (MNHN-IB-2008-2470).

\section{Description}

Colony encrusting, unilaminar, multiserial, forming small patches (Fig. 13A). Zooids large, particularly broad, polygonal, separated by deep grooves (Fig. 13B-C); lateral walls relatively reduced, becoming slightly more extensive distally, communication via one or two basal pore chambers per neighbouring zooid (Fig. 13E), outer surface gymnocystal, pore windows very elongate, surrounded by cryptocystal calcification with a reticulate surface, distal pore enlarged. Frontal shield entirely made of cryptocystaltype calcification, convex, rising distally to form a very broad bulge suborally that drops vertically towards orifice, marginally perforated by a row of variably sized pores plus a few scattered ones in central part (Fig. 13D-E); surface structure a distinct honey-comb pattern of steep ridges bounding deep depressions, covering entire frontal including avicularian cystid and suboral bulge.

Orifice D-shaped, wider than long, proximal margin straight; condyles practically absent, operculum hinged on proximal tips of lateral orifice rim; seven spines in non-maternal zooids, six in ovicellate ones with a gap between distal pair.

Ooecium kenozooidal, budded from distal septular pore of maternal zooid (Fig. 13E), hyperstomial, barely resting on frontal shield of distal zooid (Fig. 13C), globular, broader than long, with an extremely short peristome wedged in between distal pair of oral spines, terminating at distal orifice margin; ectooecium almost entirely membranous except for its very base; endooecium imperforate, surface structure as that of frontal shield (Fig. 13E); ooecial aperture suborbicular (Fig. 13D), not closed by operculum.

Adventitious avicularia paired, oval, widest in distal third, situated at distolateral zooid margin lateral to proximal half of orifice on a slightly raised cystid that extends laterally beyond zooidal boundary (Fig. 13C, E); rostrum semi-elliptical, directing laterally or distolaterally, positioned at an acute angle to frontal plane, distal uncalcified area suborbicular; mandible hinged on a pair of thin triangular condyles that usually do not fuse at centre, proximal uncalcified area semicircular (Fig. 13F).

Ancestrula tatiform, oval (ca $620 \mu \mathrm{m}$ long, $480 \mu \mathrm{m}$ wide), gymnocyst presumably very narrow all around, cryptocyst absent; opesia large (ca $470 \mu \mathrm{m}$ long, $370 \mu \mathrm{m}$ wide), oval, slightly constricted in distal part (Fig. 13B); mural spine number unknown. 

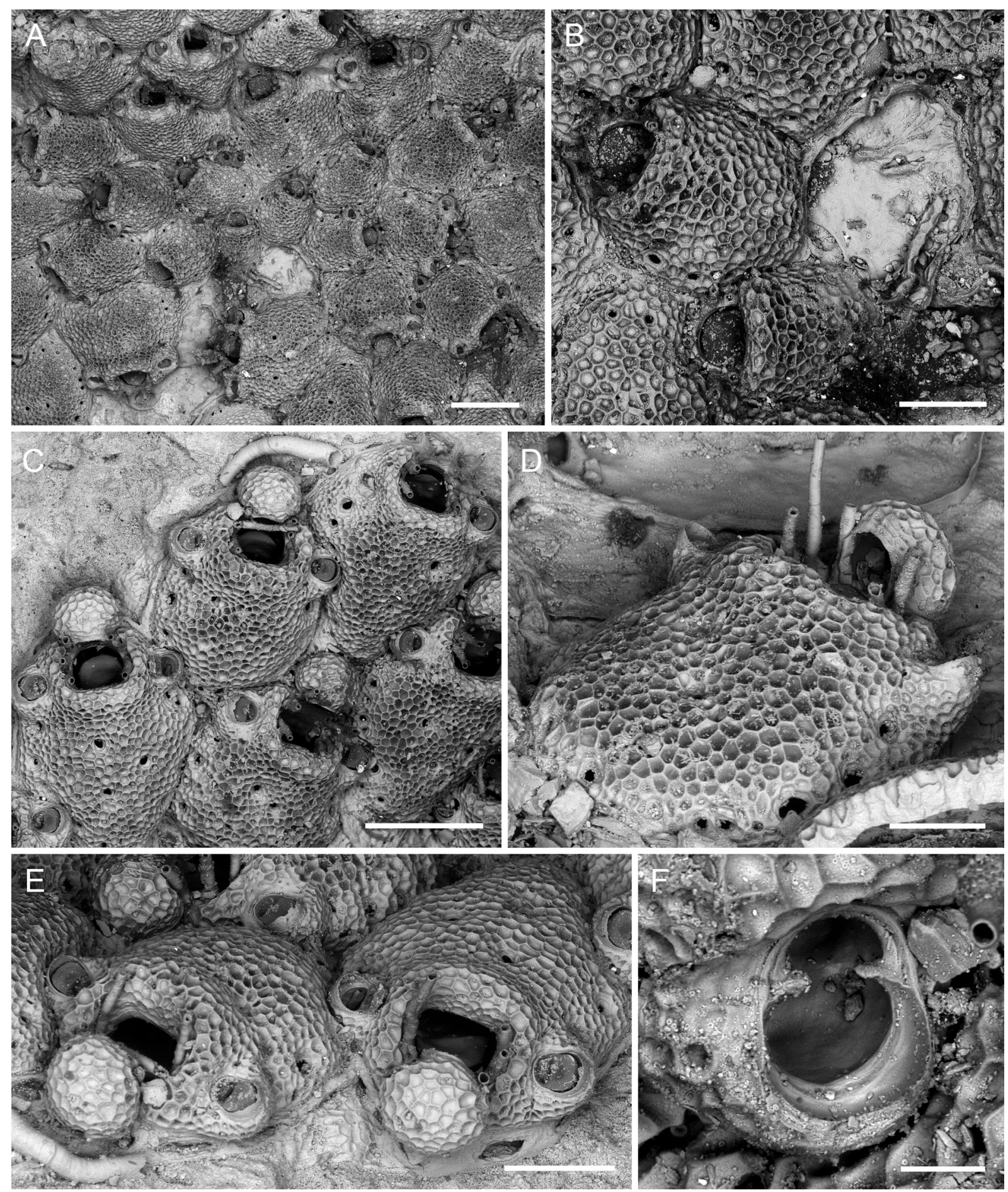

Fig. 13. Calvetopora inflata (Calvet, 1906) gen. et comb. nov., Gulf of Cádiz, holotype (MNHNIB-2008-2470). A. Overview of the periancestrular part of the colony. B. Close-up of the ancestrula and the first two autozooids. C. Maternal autozooids at the colony growth margin. D. Lateral view of an ovicellate zooid. E. Distal view of the colony growth margin showing the kenozooidal origin of the ooecia. F. Close-up of an avicularium. Scale bars: A, C $=500 \mu \mathrm{m} ; \mathrm{B}, \mathrm{D}=200 \mu \mathrm{m} ; \mathrm{E}=300 \mu \mathrm{m} ; \mathrm{F}=$ $50 \mu \mathrm{m}$. 
Table 13. Measurements of Calvetopora inflata (Calvet, 1906) gen. et comb. nov.

\begin{tabular}{ccccccccc}
\hline & ZL & ZW & OL & OW & OvL & OvW & aAL & aAW \\
\hline Mean & 845 & 656 & 180 & 214 & 232 & 292 & 123 & 97 \\
SD & \pm 84 & \pm 106 & \pm 9 & \pm 12 & \pm 20 & \pm 13 & \pm 10 & \pm 9 \\
$\#$ & 14 & 14 & 8 & 8 & 5 & 5 & 24 & 24 \\
\hline
\end{tabular}

\section{Remarks}

With its large zooids, and especially its pronounced honeycomb-like pattern covering its entire frontal and ooecial surface, Calvetopora inflata gen. et comb. nov. is an outstanding species. Similar to species of Atlantisina gen. nov., but unlike C. otapostasis gen. et sp. nov. (see below) and species of Bathycyclopora gen. nov., the ooecium is produced by a kenozooid that is budded from the maternal zooid. Although the ooecium itself is hyperstomial and in the same position as in species of Atlantisina gen. nov., the ooecium is not quite as independent of the substratum but is formed from a small basal kenozooidal chamber that is invisible in frontal view, with the kenozooid barely touching the substratum (Fig. 13E). Furthermore, the ooecium of $C$. inflata gen. et comb. nov. differs from that of most other taxa described herein, including its other congeneric species (see below), in having an almost entirely membranous ectooecium.

Not only the central pores in the frontal shield but also the series of large pores visible along the lateral zooecial margin (Fig. 13D) are apparently not areolar pores, as they are situated above the ring scar and therefore within the umbonuloid part of the frontal shield, which means they are not connected to the zooid's visceral coelom. Only the most distal ones are areolae, producing the pair of adventitious avicularia lateral to the orifice.

\section{Ecology}

The holotype encrusts a skeletal fragment of Lophelia pertusa that was recovered from $717 \mathrm{~m}$ depth.

\section{Distribution}

Calvetopora inflata gen. et comb. nov. has never been reported since the discovery of a single colony by Calvet $(1906,1907)$, although the same depth zone in the Gulf of Cádiz was resampled during the 1980s (Harmelin \& d'Hondt 1992).

Calvetopora otapostasis gen. et sp. nov. urn:1sid:zoobank.org:act:701FB911-9BE3-45A4-88A6-F6BB1E47CEFD

Fig. 14A-F, Table 14

\section{Diagnosis}

Calvetopora otapostasis gen. et sp. nov. differs from the type species $C$. inflata gen. et comb. nov. in having distinctly larger zooids, an orifice that is longer than wide and has only three to six oral spines, in the frontal shield with its granular surface structure and a higher number of central pseudopores, and in the ooecium, which is covered by a calcified ectooecium in its lower part.

\section{Etymology}

The name alludes to the two avicularia lateral to the orifice, which look like protruding ears (Latin: otapostasis); used as a noun in apposition. 
BERNING B. et al., New bathyal Bryozoa from the NE Atlantic

\section{Material examined}

\section{Holotype}

ATLANTIS SMT: 1 ovicellate colony on sandstone substratum, Stn 7 (MNHN-IB-2014-78).

\section{Paratypes}

ATLANTIS SMT: 1 colony on stylasterid skeleton, Stn 7 (MNHN-IB-2014-79); 1 isolated colony, Stn 7 (MNHN-IB-2014-80); 1 colony on stylasterid skeleton showing the ancestrula and early astogenesis, Stn 7 (MNHN-IB-2014-81); 1 coated colony on stylasterid skeleton, Stn 7 (MNHN-IB-2014-280); 3 colonies on stylasterid skeleton, Stn 7 (OLL 2016/127); 1 colony on stylasterid skeleton, Stn 7 (OLL 2016/153); 1 ovicellate colony on Dendrophyllia sp., Stn 3 (MNHN-IB-2014-82).
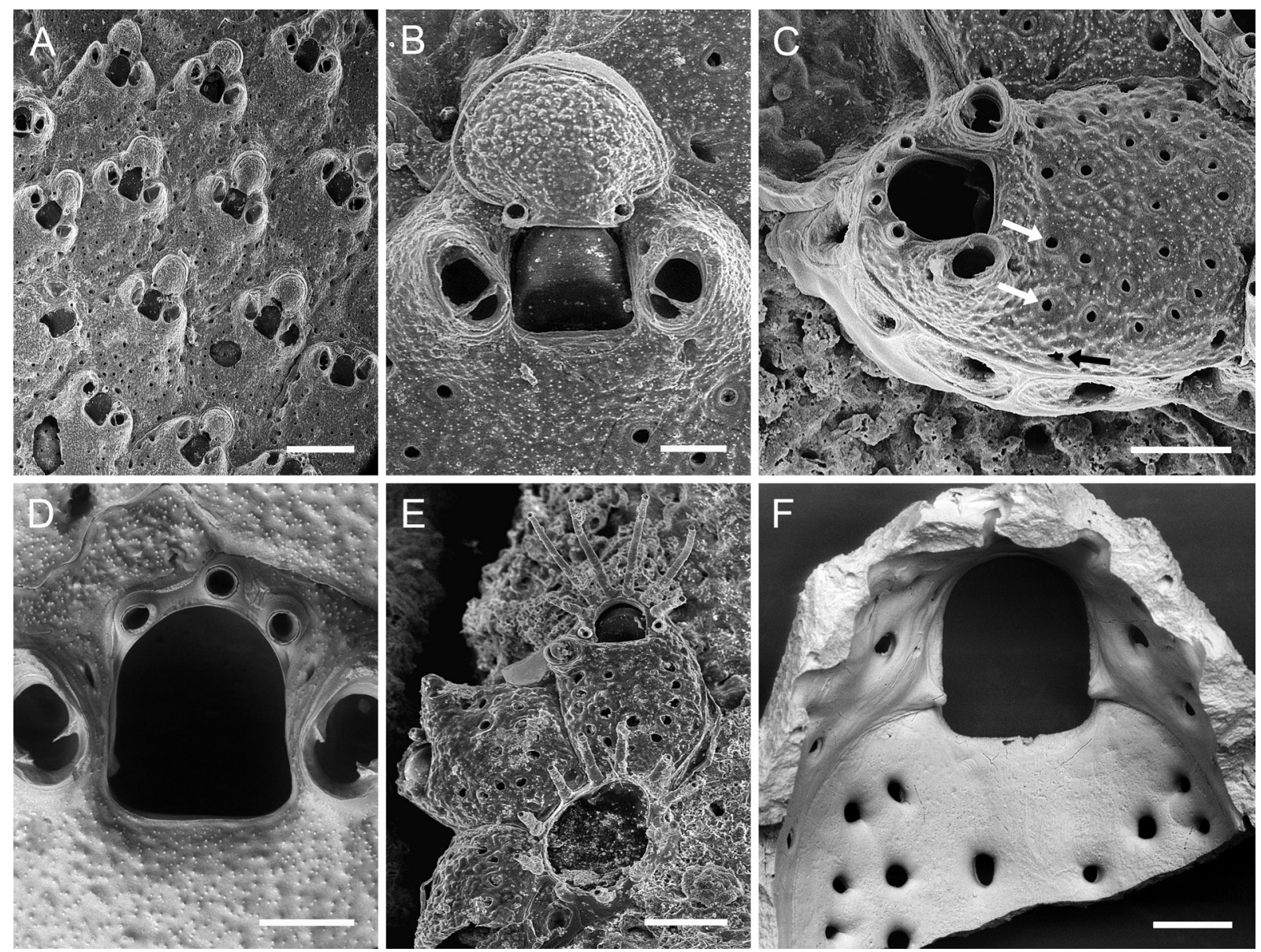

Fig. 14. Calvetopora otapostasis gen. et sp. nov., Atlantis Smt. A. Overview of the holotype (MNHNIB-2014-78). B. Close-up of an ooecium and the suboral avicularia (holotype MNHN-IB-2014-78). C. Slightly oblique view of an autozooid at the growth margin showing the communication pores in the lateral walls as well as marginal areolar pores (black arrow) and the roughly crescentically arranged pseudopores (white arrows) in the frontal shield (paratype MNHN-IB-2014-280). D. Close-up of orifice; note that the condyles are so short that usually only one can be seen (paratype OLL 2016/153). E. Ancestrula and early astogenetic autozooids (paratype MNHN-IB-2014-81). F. Interior frontal shield showing the lateral areolar pores and the central pseudopores (paratype OLL 2016/153). Scale bars: A= $500 \mu \mathrm{m} ; \mathrm{B}, \mathrm{D}, \mathrm{F}=100 \mu \mathrm{m} ; \mathrm{C}, \mathrm{E}=200 \mu \mathrm{m}$. 
Table 14. Measurements of Calvetopora otapostasis gen. et sp. nov.

\begin{tabular}{ccccccccc}
\hline & ZL & ZW & OL & OW & OvL & OvW & aAL & aAW \\
\hline Mean & 1081 & 844 & 222 & 195 & 283 & 291 & 134 & 93 \\
SD & \pm 97 & \pm 115 & \pm 8 & \pm 7 & \pm 17 & \pm 13 & \pm 22 & \pm 13 \\
$\#$ & 10 & 10 & 10 & 10 & 6 & 6 & 26 & 26 \\
\hline
\end{tabular}

\section{Other material examined}

ATLANTIS SMT: 4 colonies on stylasterid skeleton, Stn 7 (unregistered MNHN material); 1 ovicellate colony, Stn 8 (unregistered MNHN material); 1 colony on stylasterid skeleton, with Atlantisina atlantis gen. et sp. nov., Stn 7 (OLL 2016/128); 1 colony on bioclast, with Bathycyclopora suroiti gen. et sp. nov., Stn 7 (OLL 2016/151); 1 colony on stylasterid skeleton, Stn 7 (OLL 2016/154).

\section{Description}

Colony encrusting, unilaminar, multiserial, forming relatively large patches (Fig. 14A), occasionally thickened owing to self-overgrowth, sometimes growing free of substratum, producing variably thick calcified extensions from basal wall that may or may not reach substratum; cuticle iridescent in dried colonies. Zooids large, oval to pentagonal or polygonal in outline, separated by shallow grooves (Fig. 14C); lateral walls well developed, communication via two or more basal pore chambers per neighbouring zooid, gymnocystal surface reduced, extensive areas of cryptocystal calcification with a reticulate surface, each framing a large suborbicular pore window (Fig. 14C). Frontal shield matted vitreous, usually very slightly convex, entirely made of thick cryptocystal-type calcification with five to eight marginal pores and between 20 to 40 pseudopores of similar size, 12-16 outermost ones generally arranged in a peripheral U-shaped row, innermost pores occasionally arranged in a similar pattern or more scattered around a central imperforated area, each pore encircled with a faint rim; surface structure rugose with superposed fine granules (Fig. 14C).

Orifice D-shaped, longer than wide, proximal margin fairly straight or shallowly curved (Fig. 14D, F); condyles inconspicuous in frontal view, formed by a slightly rounded thickening of proximal ends of lateral orifice margin; adult non-maternal zooids usually with three oral spines on distal orifice margin (Fig. 14D), early astogenetic zooids may have up to eight spines (Fig. 14E), only two spines in ovicellate zooids (Fig. 14B).

Ooecium produced by zooid distal to maternal one, hyperstomial, resting on the distal zooid's frontal shield, globular, about as wide as long, with a short peristome wedged in between a pair of spines, terminating at distal orifice margin (Fig. 14B); ectooecium partially calcified, covering lower part of ooecium; exposed endooecium with a similar surface structure as that of frontal shield; ooecial aperture suborbicular, not closed by operculum.

Adventitious avicularia paired, ovate, situated directly lateral to orifice on a slightly raised cystid (Fig. 14B-D); rostrum semi-elliptical but occasionally asymmetric and slightly curved inwards, directing distally or distolaterally, often at an acute angle to frontal plane; distal uncalcified area suborbicular, palate a narrow distal shelf, mandible hinged on a pair of long and thin condyles occasionally fusing at centre, proximal uncalcified area semicircular.

Ancestrula tatiform with 11 spines, opesia oval (ca $305 \mu \mathrm{m}$ long, $235 \mu \mathrm{m}$ wide), constricted in distal third, gymnocyst narrowing distolaterally, cryptocyst invisible (Fig. 14E); first zooid budded distolaterally, with eight long spines, frontal shield with ca 12 large pseudopores and one adventitious avicularium. 


\section{Remarks}

With its characteristic, large-sized and strongly calcified zooids, Calvetopora otapostasis gen. et sp. nov. forms conspicuous and extensive encrusting colonies. Self-overgrowth often resulted in plurilaminar colonies, and the species is able to bridge gaps in the substratum while forming basal struts of highly variable length and width. Some zooids also showed intramural buds within otherwise undamaged zooecia, indicated by the presence of a second orifice rim with spines.

\section{Ecology}

Calvetopora otapostasis gen. et sp. nov. was mostly found encrusting dead stylasterid skeletons at depths of 280 to $460 \mathrm{~m}$.

\section{Distribution}

The species is apparently endemic to Atlantis Smt.

\section{Calvetopora sp.}

Fig. 15A-B, Table 15

\section{Material examined}

GREAT METEOR BANK: 1 small and bioeroded colony fragment free of a substrate, mounted on stub and sputter-coated, Stn 22 (OLL 2016/155); 2 small and bioeroded colony fragments free of a substrate, mounted on stub and sputter-coated, Stn 22 (OLL 2016/156); 1 small colony fragment free of a substrate, mounted on stub and sputter-coated, Stn 20, (OLL 2016/157); 3 small and bioeroded colony fragments free of a substrate, mounted on stub and sputter-coated, Stn 22 (OLL 2016/158).

\section{Remarks}

The examined specimens are very closely related to C. otapostasis gen. et sp. nov., yet differ in having smaller zooids, orifices and avicularia. Moreover, the orifice margin bears six (rarely five) spines, and the avicularia are more laterally directed (Fig. 15B). The available material, which comprises only a few small and bioeroded fragments lacking ovicells, and which were found in sediment samples, is insufficient in order to unambiguously determine whether it belongs to C. otapostasis gen. et sp. nov. or should rather be ascribed to another new species. Considering the geographic distance between Atlantis Smt and the Great Meteor Bank, however, we here treat C. otapostasis gen. et sp. nov. and Calvetopora
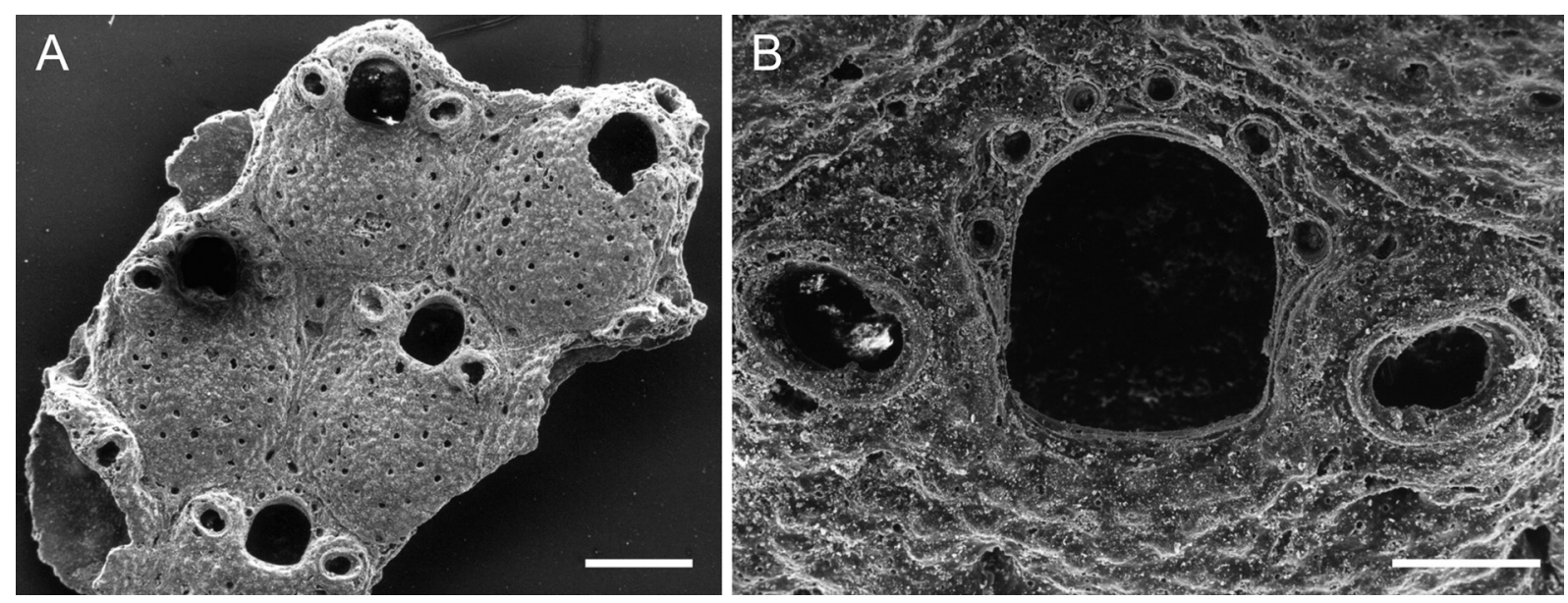

Fig. 15. Calvetopora sp., Great Meteor Bank, OLL 2016/157. A. Overview of colony fragment. B. Closeup of orifice and avicularia. Scale bars: $\mathrm{A}=300 \mu \mathrm{m}, \mathrm{B}=100 \mu \mathrm{m}$. 
Table 15. Measurements of Calvetopora sp.

\begin{tabular}{ccccccc}
\hline & ZL & ZW & OL & OW & aAL & aAW \\
\hline Mean & 905 & 625 & 201 & 176 & 118 & 85 \\
SD & \pm 123 & \pm 65 & \pm 5 & \pm 6 & \pm 11 & \pm 7 \\
$\#$ & 7 & 7 & 8 & 8 & 9 & 9 \\
\hline
\end{tabular}

sp. as distinct species. The specimens were found on the Great Meteor Bank at depths between 403 and $476 \mathrm{~m}$.

\section{Discussion}

\section{Bathyal bryozoan diversity and geographic distribution}

Recent works on bathyal bryozoans (e.g., Gordon \& Taylor 2010; Gordon 2014; Reverter-Gil et al. 2015; Souto et al. 2016) revealed an unexpected species richness, yielding numerous new taxa and showing a remarkably high degree of endemism. For instance, Souto et al. (2016) described 12 new species and three new genera from Galicia Bank, a seamount situated relatively close to the continental shelf off NW Iberia (Fig. 16). Here, we introduce another three new genera (Atlantisina gen. nov., Bathycyclopora gen. nov., Calvetopora gen. nov.) and ten new species from NE Atlantic seamounts, islands and the continental slope, for which we establish the family Atlantisinidae fam. nov. These recent discoveries testify to the high diversity of bathyal Bryozoa on the one hand, and, on the other hand, to our poor knowledge of these taxa, even at supra-specific level, and of small-sized biota attached to hard substrata in the deep sea in general.

Results of studies of particular taxonomic groups or community assemblages from seamounts are contrasted in terms of the geographical range of species: a particularly high proportion of endemics is revealed by some of them (e.g., Richer de Forges et al. 2000; George \& Schminke 2002; Gofas 2007; McClain et al. 2009) while, in contrast, other studies show a lack of endemism within seamount assemblages (e.g., Samadi et al. 2006; Thoma et al. 2009). The set of bryozoan species described here provides a striking example of endemism linked to geographic isolation between the various seamounts, islands and sites from the bathyal continental slope. Of the total of 13 species described, nine were recorded from a single seamount, island or station only (Fig. 16). This finding is consistent with the previous observation of a high percentage of bryozoan species endemic to Galicia Bank (cf. Souto et al. 2016: 452). With eight species, the genus Atlantisina gen. nov. is remarkably widespread in the central NE Atlantic, occurring on almost every seamount examined during this work with at least one species.

Species inhabited different sites only when the distance between sites was not too great, such as within the Atlantis-Great Meteor Seamount Chain or along the Iberian continental slope. For instance, Atlantisina meteor gen. et sp. nov. was recorded on the Great Meteor Bank as well as on Irving and Hyères seamounts, and Atlantisina tricornis gen. et sp. nov. occured along the Iberian slope and on Galicia Bank (Fig. 16). In these cases, however, slight morphological differences between populations were perceptible, although insufficient for discriminating them at species level based on morphology alone. Genetic studies would be necessary to test whether or not the populations are reproductively isolated and represent species complexes.

It is especially interesting to note that Atlantis Smt, the site that hosts most species (one species of each of the new genera Atlantisina gen. nov. (A. atlantis gen. et sp. nov.), Bathycyclopora gen. nov. (B. suroiti gen. et sp. nov.), and Calvetopora gen. nov. (C. otapostasis gen. et sp. nov.)) is also the most distant from the eastern Atlantic continental shelf. Moreover, six of the 13 species recorded here occur in the 
central Atlantic islands (Azores) and seamounts (Atlantis, Great Meteor, Irving, Hyères). This pattern may suggest that the central North Atlantic represents the centre of evolutionary origin of these taxa. Alternatively, this region may be interpreted as a refuge for historically more widespread and speciose taxa that have originated on the continental shelf and slope, and invaded the seamounts once these have originated. However, the biological, oceanographic and geological processes of the past that have shaped the modern-day geographical distribution of each species examined here remain unknown.

In any case, the distance between many of the seamounts, and particularly between seamount clusters, is considerable. All of the species brood their embryos, and the larvae produced are most likely shortlived (minutes to hours), like all lecithotrophic bryozoan larvae (Reed 1991: 178). Their dispersal capacity via the larval stage by means of oceanic currents is thus very low. Moreover, there is no factual indication of the possible occurrence of drifting substrata harbouring fertile colonies of these species at bathyal depths from where the taxa were reported. The ubiquitous occurrence of closely related, strictly bathyal species on distant seamounts and islands therefore defies an explanation to date. Similar

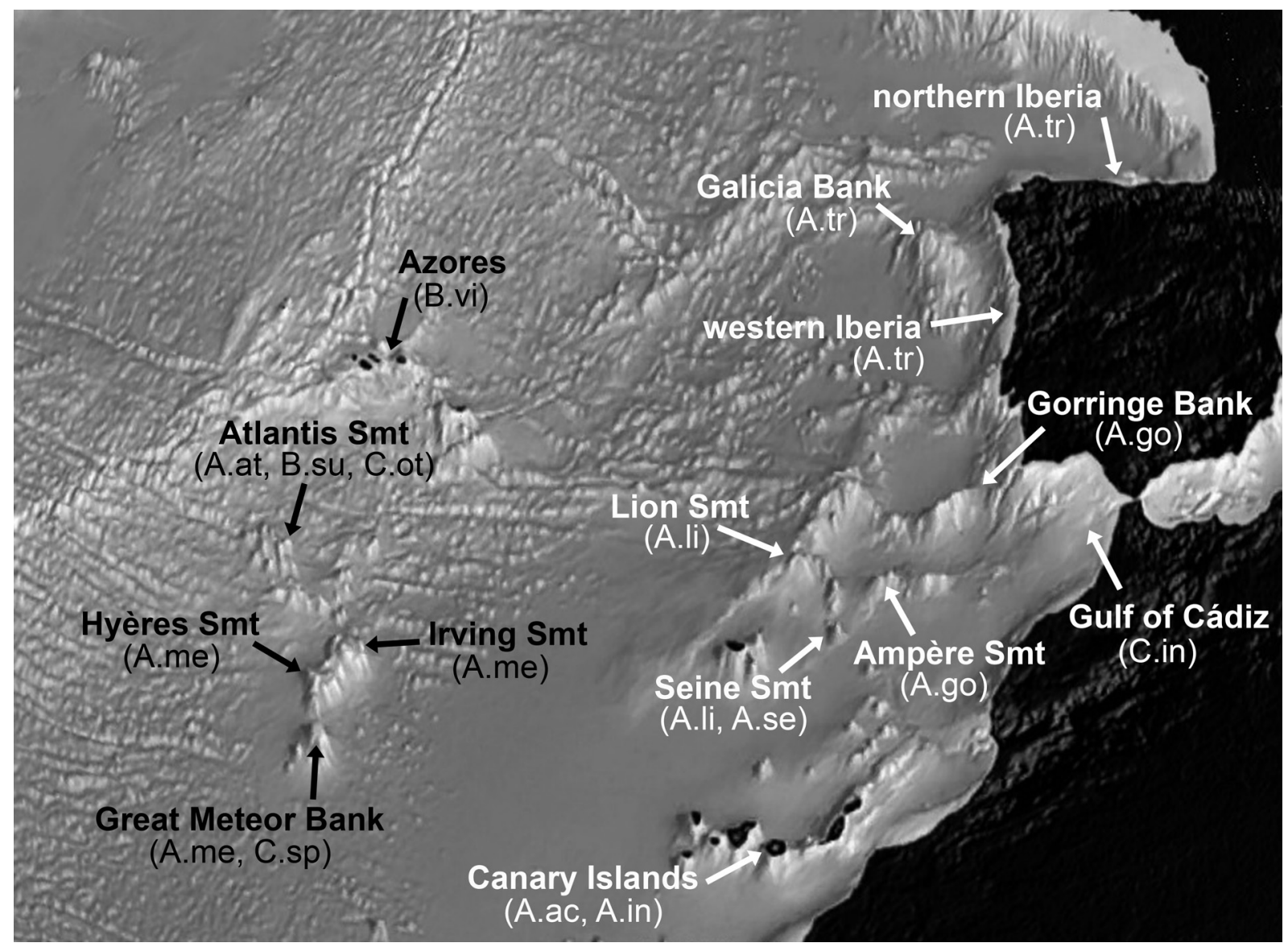

Fig. 16. Geographic distribution of the species of Atlantisina gen. nov., Bathycyclopora gen. nov. and Calvetopora gen. nov.; names in white represent sites on or close to the continental shelf, whereas names in black indicate offshore seamount and island sites. Abbreviations: A.ac = Atlantisina acantha gen. et sp. nov.; A.at = Atlantisina atlantis gen. et sp. nov.; A.go $=$ Atlantisina gorringensis gen. et sp. nov.; A.in = Atlantisina inarmata gen. et sp. nov.; A.li = Atlantisina lionensis gen. et sp. nov.; A.me = Atlantisina meteor gen. et sp. nov.; A.se = Atlantisina seinensis gen. et sp. nov.; A.tr = Atlantisina tricornis gen. et sp. nov.; B.su = Bathycyclopora suroiti gen. et sp. nov.; B.vi = Bathycyclopora vibraculata gen. et comb. nov.; C.in =Calvetopora inflata gen. et comb. nov.; C.ot $=$ Calvetopora otapostasis gen. et sp. nov.; C.sp. $=$ Calvetopora sp. 
patterns of distribution have, nevertheless, been reported from other taxa with low dispersal potential (e.g., Packmor et al. 2015). Studies on fossil bryozoans from the Azores (Ávila et al. 2015) show that at least some of the taxa characteristic of modern central and eastern Atlantic faunas were already present at these oceanic islands by the early Pliocene (see also Reverter-Gil et al. 2015: 41).

\section{Zoarial and zooidal features}

In the available material, colonies of all species occurred in the same type of micro-habitat, i.e., on hard substrata such as volcanic and sedimentary rocks, and biogenic remains (dead coral and stylasterid skeletons, shells). However, there are distinct differences in colony form between the genera introduced here.

Colonies of Atlantisina gen. nov. show characters of 'spots' (cf. Bishop 1989; Okamura et al. 2001), such as a small colony size and early maturity (with a relatively high proportion of ovicellate zooids). The colonies often consist of only a few (or occasionally a few dozen of) zooids. The small colony size, however, does not necessarily imply that the colonies are young, as often the proximal colony parts are already dead and the skeletons occasionally stained by iron oxide, mirroring conditions that have previously been reported from dark caves in shallow water (Harmelin 2000). This suggests that theses bathyal colonies grow very slowly, and that 'early maturity' has to be regarded as a relative term. Moreover, instead of forming true spot-like colonies with a subcircular perimeter, in species of Atlantisina gen. nov. one or more bi- or triserial ribbons usually lead away from the colony centre. This pattern reflects the general trend towards a greater proportion of species with pauci- or uniserial colonies with increasing depth (McKinney \& Jackson 1989: 83). Species of Bathycyclopora gen. nov., in contrast, form small multiserial patches with comparatively few ovicellate zooids, which are produced during late astogeny. Species of Calvetopora gen. nov. are particularly remarkable owing to the large size of their zooids and colonies, which often covered and monopolised large parts of the available substratum. Occasionally, the colonies were even plurilaminar owing to self-overgrowth, and at least $C$. otapostasis gen. et sp. nov. is able to grow free of a substratum and may produce calcified basal struts in this case. Moreover, reproduction also takes place during late astogeny in colonies of Calvetopora gen. nov., and ovicells are even less frequent than in Bathycyclopora gen. nov.

The species in the three different genera thus seem to follow different life history strategies. Species of Atlantisina gen. nov., with their small zooids, early maturity and a relatively great number of ovicellate zooids, can be interpreted to be opportunists that invest a comparatively great amount of energy into sexual reproduction (cf. Harmelin 1986). With species of Bathycyclopora gen. nov. taking an intermediate position, species of Calvetopora gen. nov. are at the other end of the spectrum: energy is invested in the formation of a thick frontal shield, as well as in large zooids and colonies, rather than in sexual reproduction.

In bathyal environments, competition for space, i.e., physical encounters between bryozoan colonies of the same or different species or with other encrusting taxa, is seldom observed, and the substrata are generally stable compared to many shallow-water ones. The interpretation of colony growth forms in terms of spatial competition and substratum stability/predictability, rather than in terms of life history models (cf. Hughes 1987; Bishop 1989), does therefore not readily apply to bathyal bryozoans. For instance, the directional growth of bi- to triserial colonies of species of Atlantisina gen. nov., representing the 'runner-spot intermediate' sensu Bishop (1989: 213), which may be interpreted as a fugitive strategy in shallow-water, has probably not evolved as a result of competitive inferiority or as a response to substratum instability. Instead, it seems likely that the probing growth enables the colony to reach regions on the substratum where currents are stronger, i.e., where food availability is greater. In contrast to species of Calvetopora gen. nov. with their large zooids, i.e., with long tentacles that reach far into the water column and are able to create a strong feeding current, the small zooids of Atlantisina gen. nov. may be more dependent on finding areas on the substratum that are exposed to currents. 
Intergeneric differences also exist in ooecium formation. Considering that the evolutionarily most primitive state is an ooecium formed by the zooid distal to the maternal one (Ostrovsky 2013), the taxa display different stages of an evolutionary change toward reducing the contribution of the distal autozooid to ooecium formation. In Bathycyclopora gen. nov. the ooecium is produced via an areolar pore in the proximal frontal shield of the distal zooid. As such, an ovicell can only be formed in concert with an autozooid at the colony growth margin and is never positioned at the very outer colony perimeter. The genus Calvetopora gen. nov. combines species with two different types of ooecium formation: whereas the distal zooid produces the ooecium also in $C$. otapostasis gen. et sp. nov., the ooecium in C. inflata gen. et comb. nov. is of kenozooidal origin. The kenozooid itself is already reduced to a mere small basal chamber that barely rests on the substratum (Fig. 13E) and is invisible in frontal view or once distal zooids have been formed, but when newly formed the ovicell is positioned at the outer colony edge (Fig. 13C, E). Species of Atlantisina gen. nov. are the most advanced in this respect, as the ooecial kenozooids do not encrust the substratum but are completely reduced to just the ooecium itself, which lacks communication pores and is formed via a distinct and often raised pore in the distal wall of the maternal zooid. This ooecial pore remains exposed and positioned above the frontal shields of the distally forming autozooids. The ooecia may, therefore, not only be produced at the distal colony growth margin but potentially at any time during the lifetime of the maternal zooid.

Although occurring at upper bathyal depths, where carbonate precipitation is less facile than in shallow waters, the species in all three genera produce relatively thickly calcified frontal shields. Many of these species also form additional suboral thickenings or umbones, which are particularly prominently developed in species of Atlantisina gen. nov. that live on the continental slope or on relatively nearshore seamounts (A. acantha gen. et sp. nov., A. gorringensis gen. et sp. nov., A. lionensis gen. et sp. nov., A. seinensis gen. et sp. nov., A. tricornis gen. et sp. nov.) (Fig. 16). Owing to their occurrence in every zooid as well as their robust architecture and suboral position, complementing the distolateral oral spines, these structures may have a defensive function against partial predators such as microgastropods. The absence of suboral umbones in species of Atlantisina gen. nov. that occur on the central Atlantic seamounts, on the other hand, may indicate that predation pressure is less severe there than closer to the continental shelf. It is interesting to note that colonies of $A$. inarmata gen. et sp. nov. from the Canary Islands, the only species from the easternmost Atlantic that lacks suboral umbones, were also the only one observed to have been drilled by microgastropods (Fig. 4F).

Another conspicuous character is the reticulate surface structure in Calvetopora inflata gen. et comb. nov. and three species of Atlantisina gen. nov. (A. acantha gen. et sp. nov., A. lionensis gen. et sp. nov., A. tricornis gen. et sp. nov.). A similar pattern of frontal shield calcification also occurs in other unrelated bathyal cheilostomatid taxa, e.g., Reteporella arborea Jullien, 1882, Schizomavella rectangularis Reverter-Gil, Souto \& Berning, 2015, Harpago minutus (Gordon, 1989), Ptoboroa gelasina Gordon \& d'Hondt, 1997, Siphonicytara mosaica Gordon \& d'Hondt, 1997, Trochosodon mosaicus Gordon 1989, and Pseudosclerodomus reticulatus (Busk, 1884), and also in species of the Arctic anascan genera Doryporella Norman, 1903 and Doryporellina Grischenko, Mawatari \& Taylor, 2000 (although in this case it is the cryptocyst that shows the reticulate pattern). In fact, the surface structure, with thin calcified ridges and uncalcified depressions in the species of Atlantisina gen. nov. mentioned above, is the exact opposite of that in the remaining species of Atlantisina gen. nov., in which thickly calcified nodules are separated by thin grooves. Arguably, the reticulation may confer strength to the frontal shield while minimising the amount of precipitated carbonate, which could provide an advantage in the deep sea, where cool waters are less supersaturated with carbonate ions. Moreover, the reticulate pattern is only present in species that form heavily calcified suboral structures, with the exception of $A$. lionensis gen. et sp. nov., which has the smallest suboral umbo and a nodular frontal shield as in those species of Atlantisina gen. nov. without suboral strucures. This switch in frontal shield morphology may argue for a trade-off between investment in calcification of either the suboral structure or the frontal shield. 


\section{Summary and outlook}

In conclusion, the present results attest that the bathyal bryozoan faunas of NE Atlantic seamounts, islands and the continental slope yield a great number of undescribed taxa, even at higher taxonomic levels, and provide a remarkable example of dispersal, allopatric speciation and endemism among taxa with supposedly low dispersal abilities. The colonies and zooids of many of the species show special adaptations to life in the deep sea and evolutionary trends. Many aspects of their dispersal, historical biogeography, ecology, functional morphology and evolution, however, remain elusive. This is partly due to the fact that only dry specimens from historical collections were available for study. In order to precisely address most of these aspects, and to test the morphospecies-based hypotheses, it will be necessary to collect fresh material for genetic studies.

\section{Acknowledgements}

We are grateful to all of the organisers of the scientific cruises to the NE Atlantic, in particular to P. Bouchet (MNHN) and S. Gofas (University of Málaga), the cruise leaders of the Seamount 1+2 expeditions, during which most of the studied material was collected. Helmut Zibrowius (Station Marine d'Endoume) is especially acknowledged for sorting out bryozoan-bearing substrata on board, including a great amount of deep-sea corals and stylasterids. We thank Dennis Gordon (National Institute for Water and Atmospheric Research) for fruitful discussions, and are grateful to Oscar Reverter-Gil (Universidade de Santiago de Compostela) and Javier Souto (University of Vienna, UV) for taking photos of colonies of A. tricornis gen. et sp. nov. from Spain and Portugal. Andrey Ostrovsky (UV) helped us understand the formation of ovicells not just in these taxa, and kindly took some of the images of B. vibraculata gen. et comb. nov., while Michèle Bruni (MOM) is thanked for sending on loan the type material of that species. B.B. acknowledges support from the SYNTHESYS Project (http://www.synthesys. info/), which is financed by the European Community Research Infrastructure Action under the FP7 "Capacities" Program, and which allowed him to study type and comparative material from the NE Atlantic at the MNHN (FR-TAF-1902). Additional financial support came from the Portuguese Funds through FCT - Foundation for Science and Technology under the UID/BIA/50027/2013 and POCI-010145-FEDER-006821. Finally, we thank two anonymous reviewers and the EJT editors for corrections and helpful comments that improved this manuscript.

\section{References}

Ávila S.P., Ramalho R.S., Habermann J.M., Quartau R., Kroh A., Berning B., Johnson M.E., Kirby M.X., Zanon V., Titschack J., Goss A., Rebelo A.C., Melo C., Madeira P., Cordeiro R., Meireles R., Bagaço L., Hipólito A., Uchman A., da Silva C.M., Cachão M. \& Madeira J. 2015. Palaeoecology, taphonomy, and preservation of a lower Pliocene shell bed (coquina) from a volcanic oceanic island (Santa Maria Island, Azores). Palaeogeography, Palaeoclimatology, Palaeoecology 430: 57-73. https:// doi.org/10.1016/j.palaeo.2015.04.015

Bartsch I. 2008. Notes on ophiuroids from the Great Meteor Seamount (Northeastern Atlantic). Spixiana 31: 233-239.

Berning B. 2008. Evidence for sublethal predation and regeneration among living and fossil ascophoran bryozoans. In: Hageman S.J., Key M.M. \& Winston J.E. (eds) Bryozoan Studies 2007. Virginia Museum of Natural History Special Publication 15: 1-7.

Berning B. 2012. Taxonomic notes on some Cheilostomata (Bryozoa) from Madeira. Zootaxa 3236: $36-54$.

Berning B. 2013. New and little-known Cheilostomata (Bryozoa, Gymnolaemata) from the NE Atlantic. European Journal of Taxonomy 44: 1-25. https://doi.org/10.5852/ejt.2013.44 
BERNING B. et al., New bathyal Bryozoa from the NE Atlantic

Berning B. \& Kuklinski P. 2008. North-east Atlantic and Mediterranean species of the genus Buffonellaria (Bryozoa, Cheilostomata): implications for biodiversity and biogeography. Zoological Journal of the Linnean Society 152: 537-566. https://doi.org/10.1111/j.1096-3642.2007.00379.x

Bishop J.D.D. 1989. Colony form and the exploitation of spatial refuges by encrusting Bryozoa. Biological Reviews 64: 197-218. https://doi.org/10.1111/j.1469-185X.1989.tb00675.x

Busk G. 1884. Report on the Polyzoa. Part I. The Cheilostomata. Report of the Scientific Results of the Voyage of H.M.S. Challenger during the years 1873-76 10: 1-216.

Calvet L. 1906. Note préliminaire sur les bryozoaires recueillis par les expéditions du Travailleur (1881-1882) et du Talisman (1883). Bulletin du Muséum national d'Histoire naturelle 12: 154-166.

Calvet L. 1907. Bryozoaires. In: Milne-Edwards A. \& Perrier E. (eds) Expéditions scientifiques du "Travailleur" et du "Talisman" pendant les années 1880-1883, Vol. 8: 355-495. Masson et C ${ }^{\mathrm{ie}}$, Paris.

Calvet L. 1931. Bryozoaires provenant des campagnes scientifiques du Prince Albert $1^{\text {er }}$ de Monaco. Résultats des Campagnes Scientifiques du Prince Albert 1 ${ }^{\text {er }}$ de Monaco 83: 1-152.

Christiansen B., Martin B. \& Hirch S. 2009. The benthopelagic fish fauna on the summit of Seine Seamount, NE Atlantic: composition, population structure and diets. Deep-Sea Research II 56: 27052712. https://doi.org/10.1016/j.dsr2.2008.12.032

Geldmacher J., Hoernle K., Klügel A., van den Bogaard P., Wombacher F. \& Berning B. 2006. Origin and geochemical evolution of the Madeira-Tore Rise (eastern North Atlantic). Journal of Geophysical Research 111: B09206. https://doi.org/10.1029/2005JB003931

George K.H. \& Schminke H.K. 2002. Harpacticoida (Crustacea, Copepoda) of the Great Meteor Seamount, with first conclusions as to the origin of the plateau fauna. Marine Biology 144: 887-895. https://doi.org/10.1007/s00227-002-0878-6

Gillet P. \& Dauvin J.-C. 2003. Polychaetes from the Irving, Meteor and Plato seamounts, North Atlantic Ocean: origin and geographical relationships. Journal of the Marine Biological Association of the United Kingdom 83: 49-53.

Gofas S. 2007. Rissoidae (Mollusca: Gastropoda) from northeast Atlantic seamounts. Journal of Natural History 41: 779-885. https://doi.org/10.1080/00222930701298085

Gordon D.P. 2014. Apprehending novel biodiversity - fifteen new genera of Zealandian Bryozoa. Journal of the Marine Biological Association of the United Kingdom 94 (8): 1597-1628. https://doi. org/10.1017/S0025315414000599

Gordon D.P. \& Taylor P.D. 2010. New seamount- and ridge-associated cyclostome Bryozoa from New Zealand. Zootaxa 2533: 43-68.

Harmelin J.-G. 1977. Bryozoaires du Banc de la Conception (nord des Canaries). Campagne Cineca I du "Jean Charcot". Bulletin du Muséum national d'Histoire naturelle, 3e sér. 492: 1057-1076.

Harmelin J.G. 1986. Patterns in the distribution of bryozoans in the Mediterranean marine caves. Stygologia 2: 10-25.

Harmelin J.-G. 2000. Ecology of cave and cavity dwelling bryozoans. In: Herrera Cubilla A. \& Jackson J.B.C. (eds) Proceedings of the $11^{\text {th }}$ International Bryozoology Association Conference: 38-53. Smithsonian Tropical Research Institute, Panama City.

Harmelin J.-G. 2006. The Puellina flabellifera species complex: a remarkable example of worldwide species radiation in cribrimorph bryozoans. Courier Forschungsinstitut Senckenberg 257: 73-91. 
Harmelin J.-G. \& Arístegui J. 1988. New Cribrilinidae (Bryozoa, Cheilostomata) from the upper bathyal of the Atlanto-Mediterranean region. Journal of Natural History 22: 507-535. https://doi. org $/ 10.1080 / 00222938800770351$

Harmelin J.-G. \& d'Hondt J.-L. 1992. Bryozoaires des parages de Gibraltar (campagne océanographique BALGIM, 1984). 1 - Chéilostomes. Bulletin du Muséum national d'Histoire naturelle, 4e sér. 14: 23-67.

Hayward P.J. 1978. Bryozoa from the west European continental slope. Journal of Zoology 184: 207224. https://doi.org/10.1111/j.1469-7998.1978.tb03276.x

Hayward P.J. \& Ryland J.S. 1999. Cheilostomatous Bryozoa. Part 2. Hippothooidea - Celleporoidea. Synopses of the British Fauna 14: 1-416.

Heinz P., Ruepp D. \& Hemleben C. 2004. Benthic foraminifera assemblages at Great Meteor Seamount. Marine Biology 144: 985-998. https://doi.org/10.1007/s00227-003-1257-7

Hondt J.-L. d' 1973. Bryozoaires et brachiopodes de la campagne Noratlante. Bulletin du Muséum national d'Histoire naturelle, $3^{e}$ sér. 179: 1209-1223.

Hondt J.-L. d' 1974. Bryozoaires récoltés par la "Thalassa" dans le Golfe de Gascogne (Campagnes de 1968 à 1972). Cahiers de Biologie Marine 15: 27-50.

Hondt J.-L. d' 1975. Bryozoaires cténostomes et cheilostomes (Cribrimorphes et Escharellidae exceptés) provenant des dragages de la campagne océanographique Biaçores du "Jean Charcot". Bulletin du Muséum national d'Histoire naturelle, $3^{e}$ sér. 299: 553-600.

Hughes R.N. 1987. The functional ecology of clonal animals. Functional Ecology 1: 63-69.

Jullien J. \& Calvet L. 1903. Bryozoaires provenant des campagnes de l'Hirondelle (1886-1888). Résultats des Campagnes Scientifiques du Prince de Monaco 23: 1-188.

López-Fé C.M. 2006. Some bathyal cheilostome Bryozoa (Bryozoa, Cheilostomata) from the Canary Islands (Spain, Eastern Atlantic), with descriptions of three new species, a new genus, and a new family. Journal of Natural History 40: 1801-1812. https://doi.org/10.1080/00222930601043763

McClain C.R. 2007. Seamounts: identity crisis or split personality? Journal of Biogeography 34: 20012008. https://doi.org/10.1111/j.1365-2699.2007.01783.x

McClain C.R., Lundsten L., Ream M., Barry J. \& DeVogelaere A. 2009. Endemicity, biogeography, composition, and community structure on a Northeast Pacific seamount. PLoS ONE 4 (1): e4141. https:// doi.org/10.1371/journal.pone.0004141

McKinney F.K. \& Jackson J.B.C. 1989. Bryozoan Evolution. Unwin Hyman, Boston.

Okamura B., Harmelin J.-G. \& Jackson J.B.C. 2001. Refuges revisited. Enemies versus flow and feeding as determinants of sessile animal distribution and form. In: Jackson J.B.C., Lidgard S. \& McKinney F.K. (eds) Evolutionary Patterns. Growth, Form, and Tempo in the Fossil Record: 61-93. The University of Chicago Press, Chicago.

Ostrovsky A.N. 2013. Evolution of Sexual Reproduction in Marine Invertebrates. Example of Gymnolaemate Bryozoans. Springer, Dordrecht.

Packmor J., Müller F. \& George K.H. 2015. Oceanic islands and seamounts as staging posts for Copepoda Harpacticoida (Crustacea) - shallow-water Paramesochridae Lang, 1944 from the North-East Atlantic Ocean, including the (re-)description of three species and one subspecies from the Madeiran Archipelago. Progress in Oceanography 131: 59-81. https://doi.org/10.1016/j.pocean.2014.11.012

Reed C.G. 1991. Bryozoa. In: Giese A.C., Pearse J.S. \& Pearse V.B. (eds) Reproduction of Marine Invertebrates: 85-245. Boxwood Press, Pacific Grove. 
Reverter-Gil O. \& Souto J. 2015. Redescription of some species of Bryozoa described by J. Jullien and L. Calvet in the NE Atlantic. European Journal of Taxonomy 157: 1-17. https://doi.org/10.5852/ ejt.2015.157

Reverter-Gil O., Berning B. \& Souto J. 2015. Diversity and systematics of Schizomavella species (Bryozoa: Bitectiporidae) from the bathyal NE Atlantic. PLoS ONE 10 (10): e0139084. https://doi. org/10.1371/journal.pone.0139084

Richer de Forges B., Koslow J.A. \& Poore G.C.B. 2000. Diversity and endemism of the benthic seamount fauna in the southwest Pacific. Nature 405: 944-947. https://doi.org/10.1038/35016066

Rowden A.A., O'Shea S. \& Clark M.G. 2002. Benthic biodiversity of seamounts on the northwest Chatham Rise. Marine Biodiversity Biosecurity Report 2: 1-21.

Rowden A.A., Clark M.R. \& O'Shea S. 2004. Benthic biodiversity of seamounts on the Northland Plateau. Marine Biodiversity Biosecurity Report 5: 1-21.

Samadi S., Bottan L., Macpherson E., Richer de Forges B. \& Boisselier M.C. 2006. Seamount endemism questioned by the geographical distribution and population genetic structure of marine invertebrates. Marine Biology 149: 1463-1475. https://doi.org/10.1007/s00227-006-0306-4

Souto J., Reverter-Gil O. \& Fernández-Pulpeiro E. 2011. Redescription of some bryozoan species originally described by J. Jullien from Iberian waters. Zootaxa 2827: 31-53.

Souto J., Berning B. \& Ostrovsky A.N. 2016. Systematics and diversity of deep-water Cheilostomata (Bryozoa) from Galicia Bank (NE Atlantic). Zootaxa 4067 (4): 401-459. https://doi.org/10.11646/ zootaxa.4067.4.1

Stocks K. 2004. Seamount invertebrates: composition and vulnerability to fishing. In: Morato T. \& Pauly D. (eds) Seamounts: Biodiversity and Fisheries. Fisheries Centre Research Reports 12: 17-24.

Thoma J.N., Pante E., Brugler M.A. \& France S.C. 2009. Deep-sea octocorals and antipatharians show no evidence of seamount-scale endemism in the NW Atlantic. Marine Ecology Progress Series 397: 25-35. https://doi.org/10.3354/meps08318

Xavier J.R. \& van Soest R.W.M. 2007. Demosponge fauna of Ormonde and Gettysburg Seamounts (Gorringe Bank, north-east Atlantic): diversity and zoogeographical affinities. Journal of the Marine Biological Association of the United Kingdom 87: 1643-1653. https://doi.org/10.1017/ $\underline{\mathrm{S} 0025315407058584}$

Manuscript received: 24 October 2016

Manuscript accepted: 22 December 2016

Published on: 31 August 2017

Topic editor: Rudy Jocqué

Desk editor: Kristiaan Hoedemakers

Printed versions of all papers are also deposited in the libraries of the institutes that are members of the EJT consortium: Muséum national d'Histoire naturelle, Paris, France; Botanic Garden Meise, Belgium; Royal Museum for Central Africa, Tervuren, Belgium; Natural History Museum, London, United Kingdom; Royal Belgian Institute of Natural Sciences, Brussels, Belgium; Natural History Museum of Denmark, Copenhagen, Denmark; Naturalis Biodiversity Center, Leiden, the Netherlands; Museo Nacional de Ciencias Naturales-CSIC, Madrid, Spain; Real Jardín Botánico de Madrid CSIC, Spain. 